\title{
EFEITO DO PROCESSAMENTO DO GRÃO DE MILHO E SUA SUBSTITUIÇÃO PARCIAL POR POLPA DE CITROS PELETIZADA SOBRE O DESEMPENHO, DIGESTIBILIDADE DE NUTRIENTES E PARÂMETROS SANGUÍNEOS DE VACAS DE LEITE
}

\author{
MÁRIO PROCÓPIO MENEZES JÚNIOR
}

Médico Veterinário

Orientador: Prof. Dr. FLÁVIO AUGUSTO PORTELA SANTOS

Dissertação apresentada à Escola Superior de Agricultura "Luiz de Queiroz", Universidade de São Paulo. para obtenção do título de Mestre em Agronomia. Área de Concentração: Ciência Animal e Pastagens.

PIRACICABA

Estado de São Paulo - Brasil

Março - 1999 
Dados Internacionais de Catalogação na Publicação (CIP) DIVISÃo DE BIBLIOTECA E DOCUMENTAÇÃO - Campus "Luiz de Queiroz"/USP

Menezes Júnior, Mário Procópio

Efeito do processamento do grão de milho e sua substituição parcial por polpa de citros peletizada sobre o desempenho, digestibilidade de nutrientes e parâmetros sanguineos de vacas de leite / Mário Procópio Menezes Júnior. - - Piracicaba, 1999.

$97 \mathrm{p}$.

Dissertaçāo (mestrado) - - Escola Superior de Agricultura Luiz de Queiroz, 1999. Bibliografia.

1. Desempenho animal 2. Dieta animal 3. Digestibilidade 4. Nutrição animal 5. Polpa de fruta 6. Silagem de milho 7. Vaca holandesa 8. Vaca leiteira 9. Valor nutritivo 
Aos meus queridos pais,

Célia e Mário, pelo incentivo, amizade e carinho,

Aos meus queridos irmãos,

Marcelo (Téo), Mauro Sérgio (Dédo) e Maria Carolina (Carol), pela eterna amizade e cumplicidade,

DEDICO. 


\section{AGRADECIMENTOS}

À Escola Superior de Agricultura Luiz de Queiroz (USP) e ao Departamento de Produção Animal, pela oportunidade de realização deste curso.

À Coordenadoria de Aperfeiçoamento de Pessoal de Nível Superior (CAPES), pela concessão da bolsa de estudos.

À Sul Mineira Alimentos (Pouso Alegre -MG), pela doação do milho floculado utilizado neste trabalho.

Ao Prof. Dr. Flávio Augusto Portela Santos, pela orientação segura, pelos ensinamentos valiosos, pela amizade, confiança e exemplo profissional.

Ao Prof. Dr. José Manuel Correa de Simas, pelas sugestões, colaboração na execução deste trabalho, pela amizade e exemplo profissional.

Ao Prof. Dr. Alexandre Vaz Pires, pela amizade, pelos ensinamentos e realização das cirurgias nos animais para implantação das cânulas.

Ao Prof. Msc. Milton Luiz Moreira Lima (UFGO), pela amizade, pelos ensinamentos valiosos e exemplo profissional.

Aos demais professores do Departamento de Produção Animal, pelos ensinamentos e pela amizade.

Aos colegas Maria Tereza Guidi, Paulo Farano Stachini, Maria Cláudia Araripe Sucupira, Soraia Vanessa Matarazzo, Cláudio Vaz Di Mambro Ribeiro, pela amizade e pela colaboração durante a execução deste trabalho. 
Aos estagiários Ribamar, Vurva, Meloso e Vasenol pela primorosa ajuda durante os períodos experimentais.

Ao funcionário do Laboratório de Bromatologia e Nutrição Animal do Departamento de Produção Animal Carlos César Alves, pela amizade, paciência e pela colaboração nas análises químicas.

Aos demais funcionários e colegas do curso de pós-graduação, pela amizade, pela ajuda e pela agradável convivência.

Aos meus pais Célia e Mário e aos meus irmãos Marcelo, Mauro Sérgio e Maria Carolina, pela confiança e grande estímulo para execução deste trabalho.

À Luciana, pelo amor e incentivo ao longo de todos esses anos juntos.

À Cria Bem Nutrição Animal, sediada em Goiânia (GO), pela oportunidade de dar os primeiros passos na área de nutrição animal e pelo incentivo depositado durante a realização deste trabalho.

Às pessoas que, direta ou indiretamente, contribuiram para a realização deste trabalho.

OBRIGADO. 


\section{SUMÁRIO}

Página

LISTA DE FIGURAS viii

LISTA DE TABELAS ix

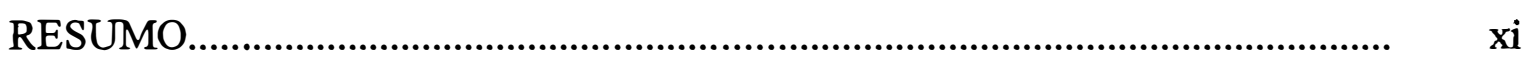

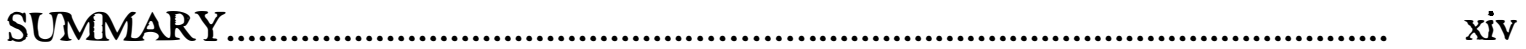

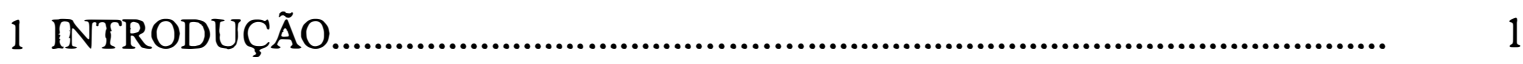

2 REVISÃO DE LITERATURA............................................................

2.1 Amido.............................................................................................. 3

2.1.1 Propriedades químicas e fisicas do amido................................................... 3



2.1.2.1 Fatores que afetam a degradabilidade ruminal do amido ........................... 8

2.1.3 Síntese de proteína microbiana no rúmen....................................................... 9

2.1.4 Digestão intestinal do amido......................................................................... 14

2.1.5 Absorção de glucose e metabolismo pelos tecidos viscerais........................... 17

2.1.6 Absorção de AGVs e metabolismo pelos tecidos viscerais........................... 19

2.1.7 Efeito da floculação (steam flake) do grão de cereais na digestibilidade do amido e outros nutrientes da dieta, na eficiência alimentar, produção e composição do leite........................................................................................ 22

2.2 Polpa de citros peletizada como fonte de energia para ruminantes.................. 27

2.2.1 Histórico Geral....................................................................................... 27 
2.2.2 Valor nutritivo e características de fermentação ruminal.

2.2.3 Efeito da utilização da polpa de citros sobre a digestibilidade de nutrientes, eficiência alimentar, produção e composição do leite.

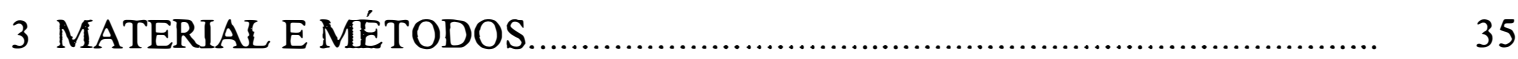

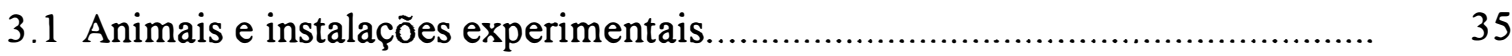

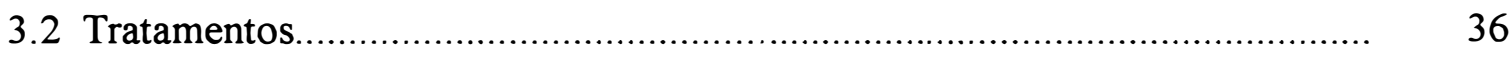

3.2.1 Processamento e determinação do tamanho de partículas do grão de milho 37

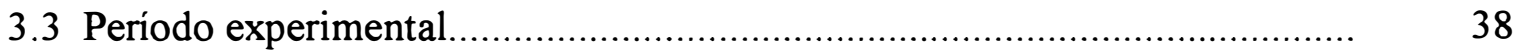

3.3.1 Coleta de dados referentes ao consumo de matéria seca por parte dos

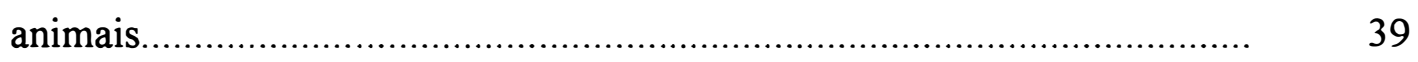

3.3.2 Análises bromatológicas das dietas e do recusado............................... 39

3.3.3 Coleta de fluído ruminal para determinação de AGVs, N-NH3 e pH ruminal.

3.3.4 Coleta de conteúdo duodenal para determinação da digestibilidade de nutrientes e fluxo de proteína microbiana......

3.3.5 Coleta de fezes para determinação da digestibilidade aparente do trato total.

3.3.6 Coleta de sangue para determinação de glucose e uréia plasmática.

3.3.7 Avaliação da produção e composição do leite.

3.4 Análise estatística.

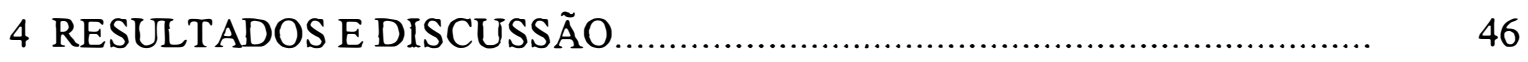

4.1 Composição dos alimentos utilizados...................................................... 46

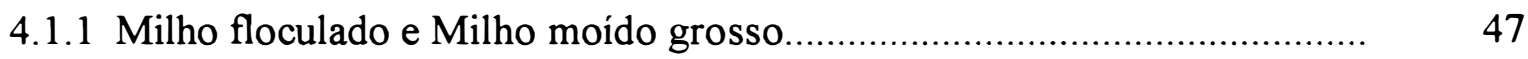

4.1.2 Polpa de citros peletizada .............................................................. 48

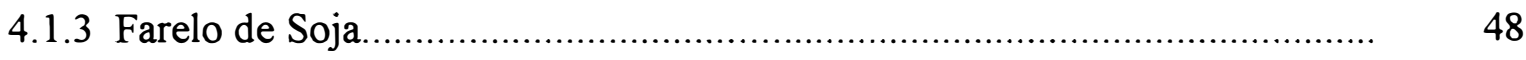

4.1.4 Silagem de Milho .......................................................................... 49

4.2 Taxa de hirólise enzimática do amido..................................................... 49

4.3 Fluxo de proteína microbiana e digestibilidade aparente de nutrientes......... 50

4.4 Consumo e digestibilidade aparente de nutrientes............................... 51

4.4.1 Matéria Seca e Matéria Orgânica........................................................... 51 
4.4.2 Fibra em detergente neutro e Fibra em detergente ácido......................... 55

4.4.4 Amido e Proteína Bruta..................................................................... 57

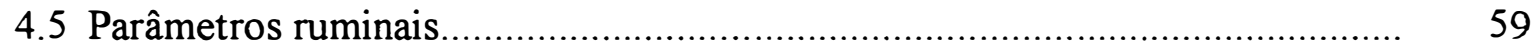

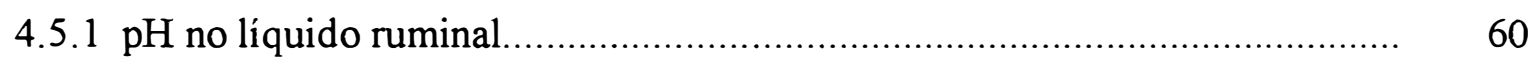

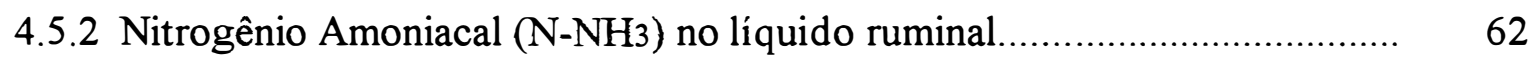



4.6.1 Concentração total de ácidos graxos voláteis...................................... 65

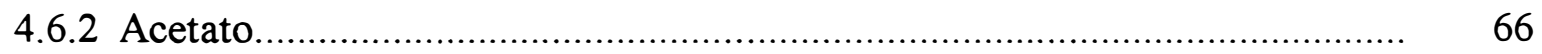

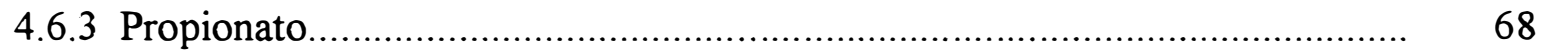



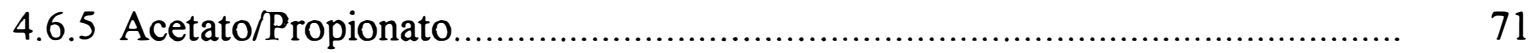



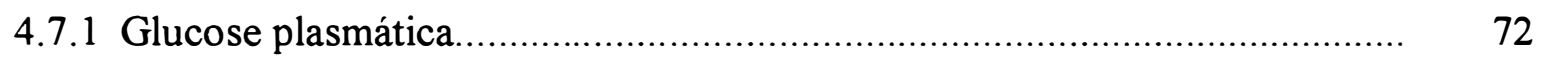

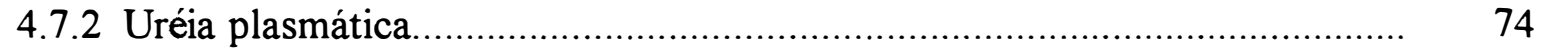

4.8 Produção, composição do leite e eficiência alimentar................................... 76

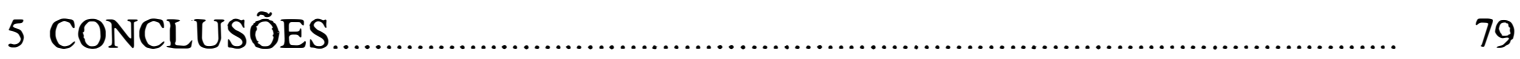

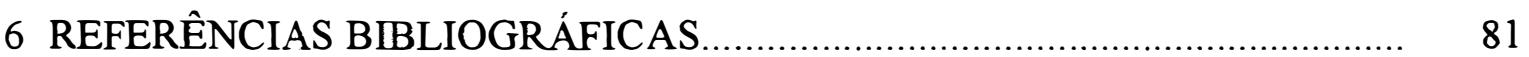




\section{LISTA DE FIGURAS}

Página

1 Taxa de Hidrólise "in vitro" do amido........................................... 50

2 Efeito das dietas experimentais sobre o $\mathrm{pH}$ ruminal nos diferentes

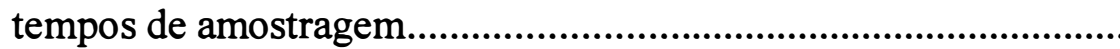

3 Efeito dos tratamentos sobre o nitrogênio amoniacal ruminal nos

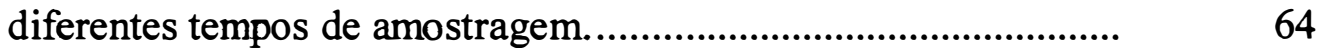

4 Efeito dos tratamentos sobre a concentração molar total de ácidos

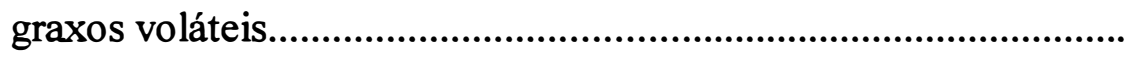

5 Efeito dos tratamentos sobrer a proporção molar de acetato

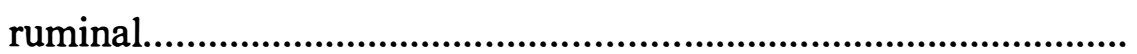

6 Efeito das dietas experimentais sobre o percentual molar de

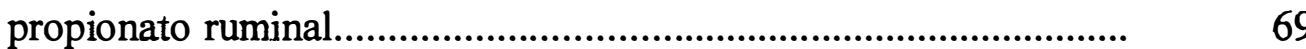

7 Efeito das dietas experimentais sobre o percentual molar de

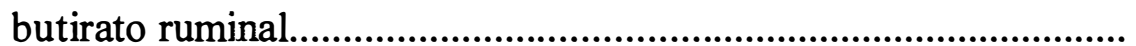

8 Efeito das dietas experimentais sobre a proporção molar de

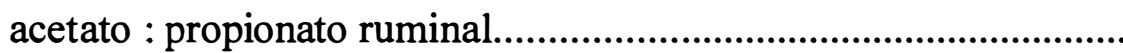

9 Efeito das dietas experimentais sobre as concentrações

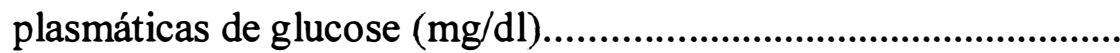

10 Efeito das dietas experimentais sobre a concentração de uréia plasmática 


\section{LISTA DE TABELAS}

Página

1 Composição das dietas experimentais em (\%) da matéria seca......

2 Tamanho de partículas e tamanho médio de partículas do milho processado

3 Quadro esquemático de análise de variância para o ensaio de

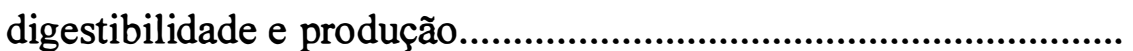

4 Quadro esquemático de análise de variância para pH, AGVs, N$\mathrm{NH}_{3}$

5 Composição química dos alimentos..................................................... 46

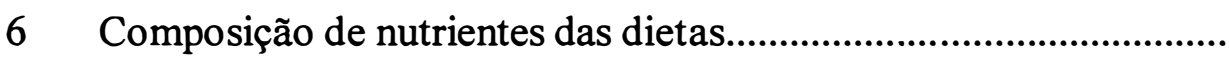

7 Efeito dos tratamentos sobre o consumo e digestibilidade aparente da matéria seca (MS) e matéria orgânica (MO) no trato digestivo total.

8 Efeito dos tratamentos no consumo e digestibilidade aparente da fibra em detergente neutro (FDN) e fibra em detergente ácido (FDA) no trato total.

9 Efeito dos tratamentos no consumo e digestibilidade aparente do amido $(\mathrm{AM})$ e da proteína $(\mathrm{PB})$ no trato total 
10 Efeito do processamento do milho e sua substituição parcial por polpa de citros peletizada sobre os parâmetros ruminais..

11 Efeito dos tratamentos sobre os parâmetros sanguíneos................ 72

12 Dados de produção e composição do leite..................................... 76 


\title{
EFEITO DO PROCESSAMENTO DO GRÃO DE MILHO E SUA SUBSTITUIÇÃO PARCIAL POR POLPA DE CITROS PELETIZADA SOBRE O DESEMPENHO, DIGESTIBILIDADE DE NUTRIENTES E PARÂMETROS SANGUÍNEOS DE VACAS DE LEITE
}

\author{
Autor : MÁRIo PROCóPIO MENEZES JúNIOR \\ Orientador : Prof. Dr. Flávio Augusto PoRTela SANTOS
}

\section{RESUMO}

Estudou-se o efeito do processamento do grão de milho e sua substituição parcial (50\%) por polpa de citros peletizada sobre o desempenho, digestibilidade de nutrientes, parâmetros ruminais e sanguíneos, utilizando-se 4 vacas holandesas com média de 120 dias em lactação. $O$ experimento foi conduzido segundo o arranjo fatorial $2 \times 2$ (dois tipos de processamento $\mathrm{x}$ inclusão ou não de polpa), no delineamento Quadrado Latino $4 \times 4$. Os animais foram alimentados com dietas contendo $50 \%$ de concentrado e $50 \%$ de 
volumoso na matéria seca. A silagem de milho foi o volumoso fornecido. Os tratamentos avaliados foram: 1) Milho moído grosso (MMG) (655 g/l); 2) Milho floculado (MF) (360 g/l); 3) Milho moído grosso (MMG) (655 g/l) + Polpa de citros (PCP); 4) Milho floculado (MF) $(360 \mathrm{~g} / \mathrm{l})+$ Polpa de citros (PCP). Houve uma tendência $(\mathrm{P}=0,14)$ de maior consumo de matéria seca e matéria orgânica para o tratamento MMG quando comparado com o MF. A floculação do milho aumentou $(\mathrm{P}<0,05)$ a digestibilidade aparente percentual da matéria seca e da matéria orgânica no trato digestivo total. Não houve efeito significativo $(\mathrm{P}>0,05)$ do tipo de processamento do milho sobre a digestibilidade aparente da FDN ou FDA, tanto em \% quanto em $\mathrm{kg}$ consumidos. A inclusão de polpa de citros peletizada aumentou $(\mathrm{P}>0,05)$ a digestibilidade aparente no trato total da FDA e da FDN, tanto em \% quanto em $\mathrm{kg}$ consumido. A digestibilidade aparente $(\%)$ do amido no trato digestivo total, foi superior $(\mathrm{P}<0,05)$ para o milho floculado comparado com o moído grosso. Houve tendência de interação entre o tipo de processamento do grão $\mathrm{x}$ inclusão de polpa $(\mathrm{P}=0,11)$, resultando em efeito benéfico da polpa de citros na digestibilidade do amido no tratamento com milho moído grosso. A floculação do milho aumentou a digestibilidade aparente da proteína bruta no trato total, reduziu $(P<0,05)$ a concentração de nitrogênio amoniacal ruminal, reduziu $(P<0,05)$ a proporção molar de acetato e aumentou $(\mathrm{P}<0,05)$ a de propionato, enquanto a inclusão de polpa de citros aumentou $(P<0,05)$ a proporção molar de acetato ruminal. Houve interação significativa $(\mathrm{P}<0,05)$ do tipo de processamento do grão $\mathrm{x}$ inclusão de polpa de citros peletizada sobre a concentração de glucose plasmática, sendo que nos tratamentos com grão a inclusão de polpa de citros peletizada diminuiu a concentração de glucose sanguínea numericamente nos tratamentos com grão floculado e aumentou no moído grosso. A concentração plasmática média de uréia foi igual para todos os tratamentos. A inclusão de polpa de citros peletizada aumentou $(\mathrm{P}<0,05)$ o teor e a produção de gordura do leite. Houve uma tendência de aumento $(\mathrm{P}=0,07)$ na produção de leite corrigido para gordura com a inclusão de polpa de citros peletizada. A floculação do milho tendeu aumentar o teor $(\mathrm{P}=0,09)$ e a produção $(\mathrm{P}=0,11)$ de proteína do leite, enquanto a inclusão de polpa de citros peletizada tendeu $(\mathrm{P}=0,13)$ a diminuir o 
teor de proteina do leite. A eficiência alimentar foi afetada positivamente $(\mathrm{P}=0,06)$ pela inclusão de polpa de citros. 


\section{EFFECT OF CORN GRAIN PROCESSING AND ITS PARTIAL REPLACEMENTS BY PELLET CITRUS PULP ON DAIRY COW PERFORMANCE, NUTRIENT DIGESTIBILITIES AND BLOOD PARAMETERS}

Author : MÁRIO ProcóPIO MENEZES JÚNIOR Adviser : Prof. Dr. Flávio Augusto Portela SANTos

\section{SUMMARY}

This trial was conducted to evalute the effect of corn grain processing and its partial replacement $(50 \%)$ by pellet citrus pulp on dairy cow performance, nutrient digestibilities, ruminal and blood parameters. Four lactating holstein cows canulated in the rumen and duodenum, averaging 120 days in milk were assingned to 4 treatments in a $4 \times 4$ Latin Square design with a $2 \times 2$ factorial arrangement. The cows were fed diets 
containing $50 \%$ of concentrate and $50 \%$ of forage on the dry matter basis. The only forage fed was corn silage. The treatments were: 1) Coarsely ground corn (MMG) (655 g/l); 2) Steam flaked corn at medium density (MF) (360 g/l); 3) Coarsely ground corn (MMG) $(655 \mathrm{~g} / \mathrm{l})+$ pellet citrus pulp (PCP); 4) Steam flaked corn at medium density (MF) $(360 \mathrm{~g} / \mathrm{l})+$ pellet citrus pulp $(\mathrm{PCP})$. Steam flaking of corn grain increased $(\mathrm{P}<0,05)$ total tract digestibility of dry matter, organic matter, starch and protein and had no effect on fiber digestibility. Increasing ruminal starch availability by flaking the corn grain, decreased rumen ammonia nitrogen indicating a higher microbial synthesis in the rumen, however, plasma urea nitrogen was not affected. Ruminal propionate was increased $(\mathrm{P}<0,05)$ and acetate was decreased $(\mathrm{P}<0,05)$ by flaking of corn. Feed efficiency, milk protein content $(\mathrm{P}=0,05)$ and yield $(\mathrm{P}=0,11)$ tended to be higher for flaked when compared with coarsely ground corn. Inclusion of pellet citrus pulp, replacing $50 \%$ of corn in the diets, did not affect dry matter intake, increased fiber digestibility and had a positive effect on starch digestibility only for the coarsely ground corn diet. Rumen ammonia nitrogen and molar proportion of propionate were not affected by citrus pulp supplementation but ruminal acetate was significantly increased. There was a significative interation $(\mathrm{P}<0,05)$ among grain processing and pellet citrus pulp on plasma glucose concentration, with pellet citrus pulp decreasing plasma glucose concentration on steam flaked corn and increasing it on coarsely ground corn diets. Feed efficiency, milk fat content and yield and yield of fat corrected milk were increased by feeding citrus pulp. Combining a higher degradable starch source (flaked corn) with a source rich in pectin, sugar and digestible fiber resulted in high milk production, feed efficiency and maximised milk components production. 


\section{INTRODUÇÃO}

As fontes de amido mais comumente utilizadas na nutrição animal são os grãos de cereais como, milho, sorgo, cevada e trigo. O milho sempre ocupou lugar de destaque, não só pelo seu comprovado valor nutritivo, como também, pela tradição de cultura em nosso país. Vale ressaltar que o amido representa cerca de $70 \%$ da matéria seca na maioria dos grãos de cereais, constituindo-se desta forma na fonte primária de energia nas dietas fornecidas para vacas holandesas com o objetivo de se obter altas produções de leite (Theurer, 1986). Pelo fato de aproximadamente 25 a $35 \%$ da matéria seca da dieta de vacas de leite de alta produção ser composta de amido, fica evidente a importância da utilização eficiente desse nutriente pelo animal.

O processamento de grãos de milho ou de sorgo através da floculação, promove alterações químicas e físicas nas moléculas do amido, facilitando a digestão por parte das enzimas amilolíticas dos microorganismos e/ou pancreáticas, resultando em um significativo aumento da degradação do amido, tanto no rúmen quanto no trato digestivo total, ou seja, melhor utilização destes grãos pelos animais. $\mathrm{O}$ aumento da degradabilidade ruminal do amido, tem se mostrado vantajoso no sentido de maximizar a capacidade fermentativa do rúmen, aumentando a síntese de proteína microbiana e a produção de ácidos graxos voláteis (AGVs), particularmente ácido propiônico, o principal precursor gluconeogênico em ruminantes. $O$ resultado pode ser um maior fluxo líquido de energia na veia porta, um aumento na síntese de glucose pelo fígado e uma maior disponibilidade de aminoácidos para a síntese de proteína do leite (Theurer, 1995). Os dados gerados nesta década mostraram que o processamento do milho e do sorgo pelo método da floculação pode resultar em aumentos da produção de 
leite da ordem de 6 a $10 \%$ e um aumento no teor protéico do leite de até $4 \%$ (Theurer, 1995; Santos, 1996).

O conhecimento básico e específico da utilização da polpa de citros peletizada como fonte de energia em substituição a uma fonte de amido convencional, em dietas para vacas de alta produção de leite, pode ajudar na viabilização da adoção da mesma como alternativa em sistemas intensivos de produção que utilizam animais de alto potencial genético para produção de leite, já que a polpa de citros peletizada possui de $85-90 \%$ do valor energético do milho ( N.R.C, 1989). Desta forma, o estudo dos parâmetros de fermentação ruminal, fluxo de nutrientes para 0 duodeno e composição do leite nos tratamentos com polpa de citros peletizada é de grande importância para que possamos estabelecer limitações e benefícios da utilização dessa fonte de energia em substituição ao amido da dieta. A polpa de citros peletizada é rica em pectina, um carboidrato altamente degradável no rúmen, mas que em comparação com o amido, promove um padrão de fermentação mais saudável com maior formação de acetato e ausência de ácido lático. Esta característica pode ser interessante quando se deseja maximizar a disponibilidade de carboidrato degradável no rúmen sem, no entanto, causar acidose (Van Soest, 1994).

O presente trabalho teve como objetivo avaliar o efeito do processamento do grão de milho (floculado ou moído grosso) e sua substituição parcial por polpa de citros peletizada, no consumo de matéria seca, produção e composição do leite, na digestibilidade de nutrientes, fluxo de aminoácidos para o duodeno e nos parâmetros ruminais e sangüíneos em vacas de leite holandesas, alimentadas com dietas contendo silagem de milho como volumoso. 


\section{REVISÃO DE LITERATURA}

\subsection{Amido}

\subsubsection{Propriedades químicas e físicas do amido}

O amido é o polissacarídeo de reserva da maioria das plantas e representa $70 \%$ da matéria seca da maioria dos cereais como milho, sorgo, cevada, trigo e aveia (Rooney \& Pflugfelder, 1986). Por representar 25 a 35\% da matéria seca das dietas para vacas de leite de alta produção, a utilização eficiente do amido é fundamental para se maximizar a produção animal (Theurer, 1986 ; Theurer, 1992).

$\mathrm{O}$ amido é um polissacarídeo heterogêneo composto de dois principais tipos de moléculas ou polímeros: amilose e amilopectina (Kotarski et al., 1992; Rooney \& Pflugfelder, 1986; Van Soest, 1994). A amilose é um polímero linear de unidades de $\mathrm{D}$-glucose unidos por ligações tipo $\alpha-1,4$, sendo que a proporção de amilose no grânulo de amido pode variar de 14 a 34\% (Kotarski et al., 1992). Segundo estes autores essa variação na proporção de amilose vai depender da espécie do grão de cereal e das variações genéticas dentro das espécies. Já a amilopectina é um polímero ramificado, consistindo de uma cadeia linear de resíduos de glucose $(\alpha-1,4)$, com pontos de ramificações $\alpha-1,6$ a cada 20 a 25 unidades, portanto, bem maior que a amilose, correspondendo a cerca de 70 a $80 \%$ da maioria do amido contido nos grãos de milho e sorgo.

O amido existe na forma de grânulos altamente organizados, nos quais a amilose e a amilopectina estão ligadas por pontes de hidrogênio. Os grânulos de 
amido são pseudo cristais que possuem regiões organizadas (cristalina) e não organizadas (amorfa). A região cristalina ou micelar é primariamente composta de amilopectina, resistente a entrada de água, ao ataque enzimático e responsável pela birefringência do grânulo de amido. A região amorfa do amido é rica em amilose e menos densa que a cristalina, permitindo um movimento livre de água (Rooney \& Pflugfelder, 1986).

$\mathrm{O}$ ataque das amilases aos grãos de amido é iniciado na região amorfa, enquanto que a hidrólise da região cristalina ocorre mais vagarosamente (Rooney \& Pflugfelder, 1986). A relação amilose : amilopectina influencia a degradabilidade do amido. Guibot \& Mercier (1985) demonstraram que o amido seroso, de baixa amilose, é mais degradável que o amido de milho comum. A menor digestibilidade das variedades de alta amilose pode estar relacionada com a maior presença de ligações de hidrogênio, o que limitaria a absorção de àgua pela molécula de amido e a hidrólise enzimática. A outra teoria que explica a menor digestibilidade da amilose reside no fato de que a mesma está localizada principalmente na região amorfa onde é complexada com lipídeos (Rooney \& Pflugfelder, 1986).

Um dos principais fatores que afetam a utilização do amido pelos animais é a presença de uma matriz protéica ao redor do grânulo de amido, a qual dificulta a ação das enzimas digestivas (Kotarski et al., 1992). A presença dessa matriz protéica é mais significativa nos grãos de sorgo e milho que nos demais cereais (Sniffen, 1980).

Os métodos de processamento geralmente estão associados com a melhoria na eficiência da utilização dos grãos e podem ser divididos em processos físicos e químicos (Nocek \& Tamminga, 1991). O grão inteiro, com o pericarpo intacto, é altamente resistente à digestão pelos ruminantes por não permitir a adesão de bactérias (Beauchemin et al., 1994; McAllister et al., 1994). O processamento físico dos grãos através da ação mecânica, consiste na quebra, moagem, trituração ou peletização de grãos secos facilitando a adesão de microorganismos aos grãos de amido. Já as modificações físico-químicas envolvem a aplicação de calor, água e pressão, os quais hidratam e incham as estruturas amorfas e cristalinas dos grãos de amido. Estas 
alterações na estrutura aumentam a digestão amilolítica por parte das enzimas de microorganismos, como também das enzimas pancreáticas. $O$ processamento físico na presença de umidade e vapor quebra a matriz e corpos protéicos, que dificultam a digestão do amido, permitindo uma maior digestão enzimática (Nocek \& Tamminga, 1991).

A floculação de grãos de cereais consiste na incubação do grão em uma câmara ou compartimento, onde o mesmo fica exposto ao calor e umidade (vapor) à pressão atmosférica por 30 a 60 minutos. Durante este processo, os grãos de amido sofrem gelatinização, uma vez que absorvem àgua, incham, exsudam parte da amilose e se tomam mais susceptíveis à degradação enzimática. A gelatinização começa na região amorfa e a penetração do calor e umidade na região cristalina ocorre mais vagarosamente. O processo é sinérgico, no que o estresse gerado pelo inchaço da região amorfa ajuda na quebra dos cristais. Prensando o grão quente e úmido em rolos reguláveis, quebra-se os grãos inchados, formando uma pasta que se toma um floco, causando um aumento na superficie de contato e susceptibilidade do amido ao ataque enzimático pois a matriz protéica é rompida. Sabe-se que a ruptura dessa matriz protéica é de grande importância na degradabilidade ruminal do amido (Rooney \& Pflugfelder, 1986). A maioria dos métodos de processamento aumentam a digestibilidade do amido no rúmen, o que usualmente aumenta a digestibilidade do amido no intestino delgado (Owens et al., 1986). O nível de floculação e gelatinização do amido são determinados pelo tempo de exposição ao vapor, temperatura, umidade do grão, tamanho e distância entre os rolos e tipo de grão. Para vacas de leite a densidade recomendada do floco é de 360g/l (Santos, 1996) e entre 320 e 360g/l (Plascencia \& Zinn, 1996). 


\subsubsection{Digestão ruminal do amido}

Em ruminantes, o amido pode ser fermentado no rúmen e no intestino grosso por microorganismos, ou digerido enzimaticamente no intestino delgado, entretanto, o princital sítio de digestão é o rúmen (Simas, 1997; Theurer, 1986 ; Theurer, 1991). Uma maior proporção do amido é digerida no rúmen quando o grão de milho é processado na forma floculada (steam flaking) ou cozido com pressão e vapor, comparados com o grão moído ou laminado a seco (Theurer, 1986). Os produtos finais da degradação (fermentação) ruminal do amido são principalmente acetato, propionato e butirato, os quais são denominados de ácidos graxos voláteis (AGVs). O subsequente metabolismo dos AGVs se constituem na maior fonte de energia para os ruminantes, podendo representar até $80 \%$ dos requerimentos energéticos diários dos animais (Bergman, 1990; Van Soest, 1994). Além da geração de energia, a fermentação ruminal de carboidratos é essencial para a nutrição protéica do ruminante, devido a importância quantitativa e qualitativa da proteína microbiana (Santos, 1996).

Vários gêneros de bactérias ruminais têm sido identificadas como sendo amilolíticas: Bacterioides, Eubacterium, Streptococcus, Butyrivibrio, Ruminobacter, Selenomonas, Succinovibrio, Succinomonas e Lactobacillus (Kotarski et al., 1992; Van Soest, 1994). Entretanto, as mais importantes espécies amilolíticas são Bacteroides amylophilus, Streptococus bovis, Succinomonas amylolitica, Bacteroides ruminicola e algumas estirpes de Bacteroides succinogenes. Essas bactérias tendem a predominar no rúmen de animais alimentados com dietas ricas em grãos (Yokoyama \& Johnson, 1988). A degradação ruminal do amido pelas bactérias amilolíticas envolve uma enzima denominada $\alpha$ - amilase extracelular a qual cliva aleatoriamente a molécula de amido (Yokoyama \& Johnson, 1988). Após o amido ser degradado a maltose e glucose as bactérias sacarolíticas irão fermentar esses substratos rapidamente até piruvato (Fahey \& Berger, 1988). Dois moles de piruvato são produzidos para cada hexose, com a produção concomitante de duas adenosinas tri-fosfato (ATP) e de dois NADH2 e o ATP gerado é a principal fonte de energia para o crescimento e mantença das bactérias 
ruminais. O Piruvato é o caminho intermediário pelo qual todos os carboidratos têm que passar antes de serem convertidos a $\mathrm{AGVs}, \mathrm{CO}_{2} \mathrm{e}$ metano. A proporção molar de $\mathrm{AGVs}$ ( $\mu \mathrm{mol})$, bem como, a proporção molar de acetato, propionato e butirato produzidos no rúmen dependem do tipo de carboidrato fermentado no rúmen, tempo e extensão da degradação, espécie de bactéria e ambiente ruminal (Bergman, 1990; Van Soest, 1994). Dietas ricas em grãos tendem a produzir maior proporção molar de ácido propiônico em relação a dietas ricas em carboidratos estruturais. Quando a degradabilidade do amido no rúmen foi aumentada através da floculação do sorgo ou através da utilização de milho grão de alta umidade, a proporção de propionato em relação ao total de AGVs aumentou 20\% (Moore et al., 1992; Oliveira et al., 1993) e 14,7\% (Lykos et al., 1997), respectivamente. Plascencia \& Zinn (1996) e Joy et al. (1997) reportaram que quando se comparou milho laminado a seco e milho floculado, a proporção molar de propionato aumentou e a proporção molar de acetato diminuiu para o tratamento milho floculado $(\mathrm{P}<0,05)$ e $(\mathrm{P}<0,01)$ respectivamente. Plascencia \& Zinn et al. (1996) ainda observaram que houve efeito linear $(\mathrm{P}<0,01)$ no decréscimo da proporção molar de acetato quando a densidade do floco diminuiu ( $390 \mathrm{~g} / 1$ até $260 \mathrm{~g} / 1$ ).

Quase a totalidade dos AGVs produzidos pelo processo fermentativo ruminal são absorvidos passivamente através do epitélio rúmen-retículo e abomaso. Sendo o rúmen-retículo, responsável por $88 \%$ dos AGVs absorvidos (Bergman, 1990). Reynolds \& Huntington (1988 a ) reportaram que $85-100 \%$ do fluxo de AGVs que chegava ao sistema portal que drena as vísceras ( PDV), ocorreu através do rúmen em animais alimentados com concentrado peletizado com grão de milho. Parte dos AGVs, durante o processo de absorção, são metabolizados pelo epitélio ruminal e o percentual de AGVs a ser metabolizado aumenta com o tamanho da cadeia e com a atividade das enzimas $C_{0}$ A Sintetase nos diferentes tecidos. Portanto, $90 \%$ do butirato produzido é metabolizado pelo epitélio ruminal sendo oxidado a $\mathrm{CO}_{2}$ e corpos cetônicos (B- hidroxibutirato, acetona e aceto-acetato), ou seja, somente $10 \%$ chega ao figado. Isto demonstra uma alta atividade da enzima Butiril $C_{0} A$ Sintetase no epitélio ruminal. Já o propionato é bem menos metabolizado pelo epitélio ruminal de vacas de leite, cerca de 3 a $15 \%$, o qual é oxidado a $\mathrm{CO}_{2}$, lactato e alanina e o restante ( $>80 \%$ do 
que é produzido) chega ao sistema porta -hepático. O propionato, como relatado anteriormente, é o maior precursor gluconeogênico em ruminantes. $\mathrm{O}$ acetato é quase todo absorvido através do epitélio ruminal. Cerca de 90 a $98 \%$ dos AGVs encontrados na circulação arterial e venosa periférica é acetato, demonstrando uma baixíssima atividade da enzima Acetil $C_{o} A$ Sintetase no epitélio ruminal e no figado. Assim sendo, o acetato é metabolizado, principalmente, pelos tecidos periféricos (adiposo e muscular) onde a atividade da enzima Acetil CoA Sintetase é muito alta (Bergman, 1990).

$\mathrm{O}$ rúmen também contém uma população de protozoários, os quais podem tem certo impacto na digestão de carboidratos através de : 1) ingestão de grânulos de amido, açúcares solúveis e pequenas partículas de plantas as quais são digeridas internamente. Esta ingestão pelos protozoários pode alterar a taxa e a extensão da fermentação do amido pela diminuição da disponibilidade desse substrato para o rápido crescimento bacteriano (Kotarski et al., 1992); 2) ingestão de bactérias em número suficiente para diminuir a taxa de fermentação ruminal. Entretanto, dietas ricas em grãos freqüentemente levam a um a queda brusca de $\mathrm{pH}$ e como os protozoários são muito sensíveis a $\mathrm{pH}$ abaixo de 6,0, não estão fortemente envolvidos em alguma apreciável extensão na modulação da taxa de fermentação de amido em ruminantes alimentados com dietas ricas em grãos.

\subsubsection{Fatores que afetam a degradabilidade ru minal do amido}

Huntington (1994 e 1997) revisando trabalhos de pesquiza realizados desde 1986, constatou que a fonte ou tipo do grão e o método de processamento deste grão têm grande influência no sítio (rúmen ou intestinos) e extensão da digestibilidade do amido. Os métodos de processamento como a floculação e os grãos de alta umidade aumentam a digestibilidade ruminal do amido do milho, sorgo, entretanto, a cevada, trigo e aveia não se beneficiam tanto com o processamento 
pois nestes os valores de digestibilidade ruminal já são elevados na ausência de processamento. Huntington (1997) sumarizou 23 trabalhos de pesquisa e encontrou os seguintes coeficientes médios de digestibilidade ruminal para o amido de diferentes tipos de grãos : milho laminado a seco $75,3 \% \pm 7.9$, sorgo laminado a seco $59,8 \% \pm$ 11,2 , cevada laminada a seco $80,7 \% \pm 3,9$, trigo laminado a seco $88,8 \%$ e aveia laminada a seco $92,7 \%$. O mesmo autor encontrou os seguintes coeficientes médios de digestibilidade ruminal para o amido de diferentes tipos de grão processados: milho floculado $84,8 \% \pm 4,1$, sorgo floculado $79 \% \pm 3,6$, cevada laminada a vapor $84,6 \%$, trigo laminado a vapor $88,1 \%$ e aveia laminada a vapor $94 \%$. Observa-se que os maiores benefícios do processamento ocorreram para o milho e sorgo os quais possuem uma matriz protéica mais intensa, sendo a matriz protéica do sorgo maior que a do milho (Sniffen, 1980; Spicer et al., 1986; Rooney \& Pflugfelder, 1986; Theurer, 1986). Segundo Hale (1973) a quebra desta matriz protéica, principalmente do grão de sorgo, é importante para uma maior utilização do amido, já que a digestibilidade da proteína e amido parecem estar diretamente relacionadas. Rooney \& Miller (1982) e Teixeira et al. (1997) também reportaram a importância do processamento na degradabilidade do amido do milho e sorgo.

\subsubsection{Síntese de proteína microbiana no rúmen}

A fermentação ruminal é o resultado de atividades físicas e microbiológicas as quais convertem componentes da dieta em produtos que são utilizados (AGVs, proteína microbiana, vitaminas do complexo B), ou não (metano e gás carbônico) pelos animais hospedeiros. Alguns, todavia, podem ser até tóxicos, como é o caso do nitrogênio amoniacal e nitratos (Owens, 1988; Van Soest, 1982 e Van Soest, 1994). 
Segundo Sniffen et al.(1992) a produção de composto nitrogenado microbiano ou proteína microbiana é resultado da eficiência microbiana (gramas de nitrogênio de origem bacteriana / kg de matéria orgânica verdadeira digerida no rúmen (MOVD) $\mathbf{X}$ a quantidade de matéria orgânica verdadeiramente digerida no rúmen ( $\mathrm{kg}$ de $\mathrm{MOVD})$ ). Pelo simples fato de que a proteína e os lipídios estão contidos na matéria orgànica e os mesmos contribuem com muito pouca energia (ATP) para os microorganismos, vários estudos têm sugerido que o mais apropriado seria expressar eficiência microbiana como função da digestão de carboidratos no rúmen. Desta forma, a produção microbiana $(\mathrm{gN})$ passa a ser resultado da quantidade de substrato fermentado no rúmen (carboidrato) e da eficiência microbiana ( $\mathrm{gN} / \mathrm{kg}$ de carboidrato fermentado).

Russel et al. (1992) reportaram que a composição bacteriana pode ser influenciada pelas mudanças nas taxas de crescimento, nas fases de crescimento e nos meios de crescimento, sendo a composição média das bactérias de $62,5 \%$ de proteína bruta, $21,1 \%$ de carboidratos, $12 \%$ de gordura e $4,4 \%$ de cinzas (na base da matéria seca). Entretanto, somente 50 a $70 \%$ do nitrogênio microbiano está disponível como aminoácidos, pois o restante faz parte da parede celular e dos ácidos nucleicos. Hungate (1966) reportou ainda, que a composição da célula microbiana depende de vários fatores, incluindo tipo microbiano, fase de crescimento e taxa de disponibilidade de nutrientes.

Os principais fatores que afetam o crescimento e a eficiência das bactérias ruminais são energia e proteína. Entretanto, existem outros fatores que afetam a fermentação ruminal como : 1) $\mathrm{pH}$ ruminal, o qual estando abaixo de 6,2 pode deprimir o crescimento de microrganismos ruminais, principalmente bactérias celulolíticas e metanogênicas; 2) taxa de passagem, pois a eficiência de crescimento de células microbianas aumenta a medida que aumenta a taxa de diluição, podendo até diminuir a extensão da digestão ruminal. Todos esses fatores são determinados pelo nível de consumo do animal, sistema de alimentação, tamanho de partícula, qualidade da forragem e proporção, tipo e processamento dos carboidratos dos alimentos (Clark et al., 1992; Huber et al., 1994; Owens, 1980; Van Soest, 1994). 
Segundo Clark et al. (1992), taxas mais rápidas de crescimento acopladas a passagens mais rápidas de microorganismos para o intestino delgado podem reduzir a reciclagem de energia e nitrogênio no rúmen por causa de um decréscimo na lise das células, decrescendo assim os requerimentos para mantença, fornecendo mais nutrientes disponíveis para o crescimento microbiano, o que melhora a eficiência de síntese microbiana no rúmen. $\mathrm{O}$ crescimento bacteriano pode ser rápido (tempo de duplicação de 14 minutos a 14 horas) e a taxa é função da disponibilidade de substrato em um intervalo de tempo conhecido.

Segundo Rode et al. (1985) a relação concentrado : volumoso pode afetar tanto e eficiência microbiana quanto a produção devido aos efeitos na disponibilidade de substrato, taxa de passagem e $\mathrm{pH}$ ruminal. A eficiência microbiana foi maior quando a proporção volumoso:concentrado foi de 80:20 (feno de alfafa), mas a produção microbiana foi maior na dietas que continham a proporção volumoso:concentrado de 38:62.

Estudos de metabolismo têm comparado diferentes fontes de grãos com diferentes degradabilidades ruminais. McCarthy et al.(1989) compararam milho moído e cevada laminada a vapor e observaram que a cevada laminada tendeu a aumentar a síntese microbiana no rúmen, porém sem nenhum efeito na eficiência microbiana. Spicer et al. (1986) compararam sorgo laminado a seco, milho laminado a seco e cevada floculada em novilhos de corte canulados, recebendo dietas com $80 \%$ de grão e observaram que o fluxo de nitrogênio microbiano para o duodeno foi maior para o tratamento com cevada. Quando a degradabilidade numinal do amido de sorgo foi aumentada através do processo de floculação, a eficiência microbiana não foi afetada, entretanto, a passagem de proteína microbiana para o duodeno foi maior comparada com o sorgo laminado a seco (Oliveira et al., 1995; Poore et al., 1993). Plascencia \& Zinn (1996) compararam milho laminado a seco e milho floculado com várias densidades (390, 320 e $260 \mathrm{~g} /$ litro) e observaram maior quantidade de nitrogênio microbiano passando para o duodeno e maior eficiência microbiana, nos tratamentos que continham milho floculado em relação ao tratamento milho laminado. Entretanto, Joy et al. (1997) comparando milho laminado a seco $(540 \mathrm{~g} / \mathrm{l})$ com milho floculado 
(390, $310 \mathrm{~g} /$ litro) não encontraram efeito do processamento sobre a eficiência microbiana nem no fluxo de nitrogênio microbiano para o duodeno. $\mathrm{O}$ mesmo aconteceu com Lykos et al. (1997) que trabalharam com diferentes taxas de degradação de carboidratos não estruturais.

$\mathrm{O}$ aumento na síntese de proteína microbiana pode melhorar a quantidade e o perfil de aminoácidos essenciais (AAE) que chegam ao duodeno para serem absorvidos, resultando especialmente em mais lisina e metionina para a síntese de leite (Santos, 1997). Estudos conduzidos nos Estados Unidos por Schwab (1994) e França por Rulquin \& Verité (1993) têm indicado que as produções de leite e de proteína do leite são maximizadas quando Lisina e Metionina representam em torno de $15 \%$ e $5 \%$ respectivamente do total de $\mathrm{AAE}$ do bolo alimentar que chega ao intestino delgado de vacas em lactação. A proteína microbiana sintetizada no rúmen é uma fonte excelente de aminoácidos e muito bem balanceada, sendo superior a qualquer suplemento protéico comumente usado em dietas para vacas de leite. Segundo o N.R.C (1985), a proteína microbiana pode suprir de 60 a $80 \%$ dos aminoácidos absorvidos pelo intestino, em ruminantes submetidos a vários estágios de produção.

Os requerimentos de nutrientes são complexos, dinâmicos e são uma função dos requerimentos de mantença como também dos requerimentos para crescimento dos microorganismos. Segundo Hoover \& Stokes (1991), as principais fontes de nitrogênio para o crescimento microbiano são peptídeos, aminoácidos e amônia, estando todos disponíveis em uma a duas horas após alimentação e logo após este período declinam até a próxima alimentação. Desta forma, a disponibilidade de proteína (percentual na matéria seca e fonte) pode ter um efeito significante na fermentação ruminal e síntese microbiana. A amônia é a principal fonte de nitrogênio para os fermentadores de carboidratos estruturais, enquanto os aminoácidos e peptídeos constituem a maior fonte de nitrogênio para os fermentadores de carboidratos não estruturais (Russel et al., 1992). A quantidade de amônia ruminal necessária para maximizar a síntese de proteína microbiana tem sido pesquizada extensivamente. Sater \& Slyter (1974) sugeriram valores de 2-3mg/100ml líquido ruminal; Slyter et al. (1979) sugeriram 2-5mg/100 ml; Clark et al. (1992) sugeriram 2-5 mg/100ml; Odle et al. 
(1987) sugeriram $12,5 \mathrm{mg} / 100 \mathrm{ml}$ (tratamento com cevada laminada) e $6,1 \mathrm{mg} / 100 \mathrm{ml}$ (tratamento milho quebrado), o que parece existir de fato é que o nível ótimo de nitrogênio amôniacal ruminal varia de acordo com a disponibilidade de carboidratos fermentáveis no rúmen. Valores bastante superiores, da ordem de $20-22 \mathrm{mg} / 100 \mathrm{ml}$ foram sugeridos por Mehrez (1977) para máxima taxa de fermentação ruminal em dietas contendo amido altamente degradável no rúmen.

Desta forma, nitrogênio e energia são requeridos em grandes quantidades e têm que estar disponíveis de maneira sincronizada para estimular rápido crescimento bacteriano. Quando o nitrogênio é degradado a uma taxa mais rápida que a fonte de energia, o excesso de amônia será carreado via sistema portal para o figado para formar uréia, uma parte será reciclada para o trato digestivo via saliva e uma grande parcela será excretada via urina, havendo perda de nitrogênio para o animal. Em contra partida quando a quantidade de energia degradada se sobrepõe a quantidade de nitrogênio ruminal disponível, o crescimento microbiano diminui (Owens et al., 1988; Huber et al., 1994).

Santos \& Huber (1995), sumarizaram trabalhos publicados no Journal of Dairy Science entre o período de 1986 a 1995. Foram cerca de 60 estudos incluindo 88 comparações do efeito da substituição de fontes ricas em proteína não degradável no rúmen por farelo de soja sobre o desempenho de vacas de leite. Resposta positiva ao suplemento com alto percentual de proteína não degradável no rúmen, na produção de leite e proteína do leite ocorreu em apenas $19 \%$ e $6 \%$ dos tratamentos comparados com farelo de soja, respectivamente. Os mesmos autores sumarizaram 11 estudos de metabolismo com vacas de leite e reportaram que as dietas onde os suplementos com alto teor de proteína não degradável no rúmen substituíram o farelo de soja, $250 \mathrm{~g}$ a menos de proteína microbiana chegavam ao intestino.

Stockes et al. (1991) observaram maior síntese de proteína microbiana quando as vacas de leite se alimentaram com dietas contendo altas proporções de carboidratos não estruturais e proteína degradável no rúmen (38 e 13,2 ou 31 e $11,8 \%$ na matéria seca da dieta) comparado com dietas contendo baixos teores de carboidratos não estruturais e proteína degradável no rúmen (24 e 9\%). 
Aldrich et al. (1993) observaram alto fluxo de proteína microbiana para o duodeno quando as vacas em lactação se alimentaram com uma dieta alta em amido degradável no rúmen (milho alta umidade) combinada com fontes de proteína de alta degradabilidade ruminal (canola e farelo de soja).

\subsubsection{Digestão in testinal do amido}

$\mathrm{O}$ amido que escapa da degradação ruminal, passa para o intestino delgado onde será degradado enzimaticamente da mesma forma como ocorre em outras espécies animais (Huntington 1994 e 1997). A digestão do amido intestinal requer enzimas capazes de clivar ligações glucosídicas $\alpha$ 1-4 e $\alpha$ 1-6. Desta forma, o pâncreas secreta a enzima $\alpha$ - amilase, a qual irá hidrolisar amilose e amilopectina em oligossacarídeos de duas (maltose) e três (maltotriose) unidades de glucose e $\alpha$ dextrinas e uma pequena quantidade de glucose. Esta fase é denominada de fase luminal da digestão (Argenzio, 1984; Gray, 1992; Harmon, 1992 a b). Como os enterócitos não absorvem moléculas de carboidrato maiores que glucose (monossacarídeo), o processo de hidrólise continua nas bordas em escova das microvilosidades intestinais através das oligossacaridases: 1) glucoamilase (maltase-glucoamilase, amiloglucosidase); 2) $\alpha$ dextrinase (isomaltase). A glucose originária desta segunda hidrólise é absorvida através de transporte ativo com sódio (Gray, 1992).

Existe uma controvérsia entre vários autores no que tange a capacidade de digestão intestinal do amido. Tem-se observado que quando se aumenta a quantidade de amido a ser digerido no intestino, ocorre redução na digestibilidade (Nocek \& Taminga, 1991), entretanto, tem havido discordâncias na literatura quanto as prováveis causas desta limitação.

Hubert et al. (1961) mostraram que a infusão abomasal de amido não foi capaz de elevar a concentração plasmática de glucose aos mesmos níveis quando 
infundiu-se quantidades similares de glucose, lactose e maltose. É possível que o intestino delgado não tenha sido capaz de digerir a quantidade de amido que veio do abomaso, o que denotaria uma limitação na capacidade de hidrólise do amido neste compartimento. Por outro lado, é possível que as vísceras drenadas pelo sistema portal hepático (PDV) tenham usado glucose de forma mais intensa quando o amido e não glucose foi suprido via infusão.

Orskov (1986) reportou que a digestão do amido no intestino delgado pode ser limitada por falta de enzimas envolvidas com a hidrólise ( $\alpha$-amilase e isomaltase) e que também existe uma capacidade limitada de absorção de glucose.

Owens et al. (1986) sugeriram não haver limitação enzimática para a digestão intestinal do amido, visto que não se atingiu um platô ou limite de quantidade de amido que desaparecera do intestino delgado. Eles propuseram que a limitação de digestão se devia a forma como este amido chegava ao intestino delgado (processamento, com alteração da matriz protéica) e o tempo de permanência (aumenta a extensão da digestão). Nesta mesma revisão, através de uma equação de regressão múltipla de 40 experimentos com novilhos de corte, os autores postularam que alterando o sítio de digestão do amido do rúmen para o intestino delgado resultaria em aumento na absorção de glucose e seria mais eficiente energeticamente que a fermentação ruminal, com um aumento de $42 \%$ na economia de energia para o animal.

Theurer (1986) mostrou que apesar da limitação, os novilhos de corte demonstraram alta capacidade de digestão de amido no intestino delgado quando quantidades de $2,0 \mathrm{~kg}$ de milho grão ou $2,5 \mathrm{~kg}$ de sorgo laminado a seco foram digeridos nesse òrgão.

Croom et al.(1992) propuseram que a incompleta digestão do amido que chega ao intestino delgado esta relacionada com uma assincronia entre o fluxo de amido que chega ao duodeno e a secreção pancreática de $\alpha$-amilase. Eles concluiram que em virtude dos ruminantes serem fermentadores pré-gástricos, os mesmos possuem um fluxo constante de bolo alimentar para o duodeno, o que impede a implementação de alguns dos controladores neuro-endócrinos da secreção pancreática como observado em outras espécies. 
Em sua revisão, Harmon (1992 b) propôs que alguns fatores da dieta poderiam estar influenciando a atividade das carboidrases na capacidade de digestão do amido no intestino delgado. Foi observado que a concentração de $\alpha$-amilase pancreática aumentou com a ingestão de energia metabolizável e não com a ingestão de amido, mas os efeitos nas dissacaridases intestinais (glucoamilase e $\alpha$-dextrinase) foram mínimos.

Hill et al. (1991) encontraram $45 \%$ de desaparecimento de amido no intestino delgado de novilhos de corte quando 430 ate $1,200 \mathrm{~g}$ de amido de sorgo chegou no duodeno. Kreikemeier et al. (1991) infundiu amido de milho no abomaso de novilhos e observou decréscimo percentual no desaparecimento de amido (86\% para $55 \%$ ) quando a quantidade de amido infundido aumentou de 480 para 1,440 g/dia.

Mais recentemente, Huntington (1997) em sua extensa revisão de literatura propôs que a absorção de glucose não é um fator limitante para a digestão de amido e que realmente existe uma limitação enzimática ( $\alpha$-amilase ). Segundo ele os estudos realizados confirmam os primeiros trabalhos que identificaram a falta de adequada atividade $\alpha$-amilase pancreática como sendo a causa primária de não haver $100 \%$ de digestão de amido no intestino delgado.

Apesar de Owens et al. (1986) postular que a digestão intestinal beneficiaria o animal em termos energéticos, trabalhos mais recentes (Reynolds, 1988a , 1988b; Huntington, 1997) demonstram que o fluxo líquido de glucose no sistema porta -hepático é nulo ou negativo, o que significa que toda a glucose que chega na glândula mamária para a síntese de lactose é proveniente da gluconeogênese hepática.

No intestino grosso, especificamente no ceco e cólon, o amido que escapou da fermentação ruminal e da digestão enzimática no intestino delgado, poderá ser fermentado por microorganismos ali existentes. A fermentação do amido no intestino grosso resulta na produção de $\mathrm{AGV}$ s e síntese de proteína microbiana. Entretanto, a proteína microbiana sintetizada não é absorvida, sendo completamente excretado através das fezes e se constituindo na maior fonte de perda de nitrogênio para o animal (N.R.C, 1985). Já, os AGVs produzidos, podem ser absorvidos e utilizados pelos ruminantes (Armentano, 1992). Theurer (1986) concluiu que o processamento do 
milho ou sorgo, aumenta a degradabilidade do amido no rúmen e intestino delgado, diminuindo o fluxo de amido e a reciclagem de $\mathrm{N}$ para o intestino grosso. Este processo provavelmente aumenta a economia de energia e $\mathrm{N}$ para o animal. Oliveira et al. (1995) em seu experimento com vacas de leite observaram que as vacas alimentadas com sorgo laminado a seco tinham mais amido e proteína nas fezes e um menor $\mathrm{pH}$ fecal quando comparadas com vacas alimentadas com sorgo floculado, sugerindo que uma quantidade significativa de amido fermento u no intestino grosso.

\subsubsection{Absorção de glucose e metabolismo pelos tecidos viscerais}

Após a digestão do amido no intestino delgado, o produto final, glucose, pode ser absorvida pelo animal. De cordo com Huntington (1997) a glucose livre presente no lúmen intestinal pode ser absorvida e transportada para o citosol do enterócito e posteriormente chegar a corrente sangüínea através de dois mecanismos: 1) transporte ativo (sódio dependente); 2) difusão paracelular. A importância dos dois sistemas está relacionada com a quantidade de glucose presente no intestino delgado. A relação entre o transporte ativo e a difusão paracelular pode ser próxima de 1:1 quando altas concentrações de glucose estam presentes no lúmen do intestino delgado de novilhos de corte adaptados. Ruminantes não necessitam ser adaptados a dietas com altas concentrações de amido para transportar glucose. Animais não adaptados mantém o transporte simultâneo de $\mathrm{Na}$ /glicose quando submetidos a um consumo de poucos polímeros glucosídicos pré-formados e o fígado aumenta a liberação de glucose (gluconeogênese) para compensar a redução de oferta para o PDV (vísceras drenadas pelo sistema porta, o qual é composto de tecidos do trato gastrintestinal, baço, pâncreas e gordura omental) para manter a homeostase. Baseado nos dados mostrados, o transporte de glucose em animais adaptados e não adaptados parece não ser o fator limitante para absorção de glucose pelo intestino delgado (Huntington, 1997). 
Uma questão de grande importância é qual a proporção de amido que chega ao intestino delgado que é atualmente absorvida como glucose e uma vez absorvida, quanto dessa glucose chega ao figado.

Vários estudos com vacas de leite têm-se limitado a mensurações "in vivo" para determinar o desaparecimento do amido (glucose) do trato gastrintestinal. Porém, estes estudos não consideram o custo do metabolismo do PDV e figado, o quais influenciam grandemente a oferta líquida de nutrientes para o figado e deste para outros tecidos (Nocek et al., 1991). Existe uma intensa atividade metabólica nos tecidos esplênicos (PDV + figado) o que resulta em uma alta taxa de consumo de oxigênio, mensurada como produção de calor atribuída ao metabolismo oxidativo. Reynolds et al.(1994) e Reynolds et al. (1988b) reportaram que 38 a 53\% do comsumo total de oxigênio pelo ruminante resultou do metabolismo esplênico e que os tecidos hepáticos tenderam a ter um maior consumo de oxigênio comparado com o PDV. A utilização de oxigênio pelo tecido hepático foi $28 \%$ maior do que pelo PDV em vacas de leite na quarta e oitava semanas pós parto. Similarmente, o fluxo sangüíneo e a produção de $\mathrm{CO}_{2}$ tenderam a ser maiores nos tecidos hepáticos do que no PDV (Reynolds et al., 1988b). Em vacas de leite (Reynolds et al., 1988a, 1988b e Reynolds \& Huntington, 1988c ), reportaram que os valores de fluxo sangüíneo são maiores em vacas lactantes que em não lactantes, resultado de uma maior ingestão de energia metabolizável, aumentando a produção de leite e aumentando o fluxo sangüíneo para o PDV e figado. Reynolds \& Huntington (1988c) reportaram que o consumo de oxigênio pelo PDV representa $4,5 \mathrm{Mcal} /$ dia ou $18 \%$ da produção total de calor em vacas leiteiras lactantes.

Retificando a grande demanda de nutrientes por parte do PDV e tecidos hepáticos, vários estudos com animais multicateterizados têm mostrado fluxo líquido negativo ou nulo de glucose pelo PDV em vacas de leite. Huntington \& Reynolds (1986) reportaram em sua avaliação o efeito da infusão abomasal de água, glicose ou amido de milho na absorção líquida de vários metabólitos em vacas de leite consumindo dietas com $60 \%$ de silagem de milho e $40 \%$ de concentrado. Eles observaram que a absorção líquida de glucose pelas vísceras drenadas pelo sistema 
porta (PDV) foi $-56,34 \mathrm{e},-46 \mathrm{mmol} / \mathrm{h}$ para água, glucose e infusão de amido, respectivamente. Cálculos para quantificar o percentual de recuperação na forma de glucose do amido e da glucose indicam $8 \%$ e $64 \%$, respectivamente.

Reynolds et al. (1988a) trabalhando com quatro vacas holandesas lactantes ( $32,2 \mathrm{~kg} / \mathrm{dia})$, consumindo uma dieta com $60 \%$ de silagem de milho e $40 \%$ de concentrado, multicateterizadas (artéria carótida, veia porta, veia mesentérica, veia hepática), de 4 a 8 semanas pós parto, observaram fluxo líquido negativo de glucose para a veja porta (com média - $59 \mathrm{mmol} / \mathrm{hora}$ ), indicando grande utilização de glucose arterial pelos tecidos viscerais (PDV).

Reynolds et at. (1994) reportaram que após a infusão de glucose em diferentes lugares como, abomaso, duodeno ou via intravenosa jugular ou mesentérica, não alterou a quantidade de glucose para o figado, assim como a produção de leite das vacas. Portanto, é de se esperar que praticamente toda a glucose utilizada para síntese de leite na glândula mamária venha da gluconeogênese no figado (Theurer, 1992; Armentano, 1992). Desta forma, como discutido anteriormente, o aumentando da digestão do amido no rúmen resulta em maior produção de AGVs, particularmente ácido propiônico , o maior precursor gluconeogênico em ruminantes. Isto se toma relevante uma vez que Kronfeld et al. (1968) calcularam que a glândula mamária de uma vaca produzindo $30 \mathrm{~kg} / \mathrm{dia}$ (1,5 $\mathrm{kg}$ de lactose) necessita de $2,2 \mathrm{~kg} / \mathrm{dia}$ de glucose.

\subsubsection{Absorção de AGVs e metabolismo pelos tecidos viscerais}

A quantidade de AGVs disponível para metabolismo pelo PDV, tecido hepático e tecidos periféricos não reflete a verdadeira quantidade produzida no rúmen, visto que os mesmos são metabolizados pelo epitélio ruminal, como discutido anteriormente. O epitélio ruminal metaboliza butirato extensamente $(90 \%$ do absorvido), alguma parte do propionato ( 3 a $15 \%$ do absorvido) e pouquíssimo acetato, 
pois $90-98 \%$ dos AGVs encontrados na circulação arterial e venosa periférica é acetato (Bergman, 1990; Reynolds \& Huntington, 1988c).

O metabolismo de AGVs pelo figado e tecidos viscerais é determinado pela atividade das enzimas $\mathrm{C}_{\mathrm{o}} \mathrm{A}$ sintetases nos diferentes tecidos. A enzima acetil $C_{o} A$ sintetase tem alta atividade nos tecidos periféricos como adiposo, muscular e glândula mamária; a enzima propionil $\mathrm{C}_{\mathrm{o}} \mathrm{A}$ sintetase tem alta atividade no figado e a enzima butiril $C_{o} \mathrm{~A}$ sintetase é ativa no epitélio ruminal e epitélio intestinal. Este parece ser um importante mecanismo para regulação de diferentes taxas de absorção individual dos AGVs pelos vários tecidos (Bergman, 1990). Estes diferentes caminhos metabólicos ficaram bem evidenciados pelo alto fluxo líquido de acetato e propionato para o PDV nos trabalhos de Reynolds \& Huntington (1988c), onde o fluxo líquido de acetato e propionato para o PDV para vacas de leite durante o período de 20 semanas foi de 920 a $1210 \mathrm{mmol} /$ hora e de 600 a $1032 \mathrm{mmol} /$ hora, respectivamente. Existe também uma diferença no fluxo líquido de AGVs de acordo com o estágio de lactação, sendo que o pico ocorre entre a oitava e décima segunda semana de lactação e está associado com um aumento na ingestão de matéria seca. Aumentos da ordem de $15 \%$ na ingestão de matéria seca resultaram em um acréscimo de $24,5 \%$ no fluxo líquido de AGVs para o PDV, quando se comparou primíparas e multíparas.

A maior parte do acetato é utilizado pela musculatura lisa do trato digestivo (fonte de energia), pelos tecidos adiposos (fonte de energia e síntese de gordura) e pela glândula mamária (fonte de energia e síntese de gordura do leite). Em trabalhos citados por Bergman (1990), em ovinos, da entrada total de acetato sangüíneo arterial $(83,21 \mathrm{mmol} / \mathrm{hora})$ pelo menos 25 a $30 \%$ foi removido e utilizado ao passar pelo PDV (23,7 mmol/hora). A produção de acetato pelo PDV (97 mmol/hora) foi maior que o fluxo líquido $(157,24 \mathrm{mmol} /$ hora veia porta $-83,21 \mathrm{mmol} /$ hora de input arterial $=74,03 \mathrm{mmol} / \mathrm{hora})$ e representou $73 \%$ do turnover total de acetato $(133$ $\mathrm{mmol} / \mathrm{hora}$ ), o que significa que uma produção endógena deve estar acontecendo nos tecidos periféricos (tecido adiposo). Do turnover total de acetato $79,5 \%$ foi utilizado pelos tecidos periféricos, $18 \%$ pelo PDV e $3 \%$ pelo figado, uma prova de que em 
ruminantes a síntese de gordura ocorre nos tecidos periféricos (tecido adiposo) e não no figado.

Da quantidade total de butirato produzido, somente $10 \%$ chegam ao figado para serem metabolizados. Do fluxo total, o figado utiliza $64 \%$, chegando a representar $84 \%$ do fluxo portal líquido (Reynolds et al.,1988 b). No figado, o butirato é transformado em ácidos graxos de cadeia longa, corpos cetônicos e $\mathrm{CO}_{2}$. A sua disponibilidade para outros tecidos é muito baixa, sendo que no tecido adiposo é utilizado na síntese de gordura e na glândula mamária para síntese de gordura do leite (Bergman, 1990).

Os ruminantes dependem e muito da síntese hepática de glucose para suprir seus requerimentos metabólicos e os principais substratos ou fontes de carbono para síntese de glucose são os ácidos orgânicos da fermentação ruminal (propionato e lactato), esqueletos carbônicos de aminoácidos deaminados e glicerol oriundo dos triglicerídeos (Huntington, 1997). Propionato, L-lactato e $\alpha$ amino-N, respondem por 75 a 90\% da gluconeogênese hepática (Theurer, 1992).

O propionato é pouco utilizado pelo PDV e pouco metabolizado a nível de epitélio ruminal. Desta forma, mais de $80 \%$ do que é produzido no rúmen chega ao figado de vacas de leite. O figado remove $85 \%$ do fluxo total ou $93 \%$ do fluxo portal líquido, o que reflete alta atividade da propionil Co A sintetase (Reynolds et al.,1988 a). Estudos com isótopos têm mostrado que o propionato oriundo da fermentação ruminal supre de 43 a $67 \%$ do carbono utilizado para a síntese de glucose no figado e que o lactato supre 12\% (Huntington et al., 1981; Veenhuizen et al., 1988; Amaral et al., 1990). A rota usual do metabolismo hepático do propionato é entrar no Ciclo dos ácidos tricarboxilicos (Ciclo de Krebs) como succinil-CoA e ser convertido em glucose. Quase $100 \%$ do propionato removido pelo figado é convertido a glucose e o pequeno percentual que escapa do metabolismo hepático é metabolizado por outros tecidos (tecido adiposo e glândula mamária). 


\subsubsection{Efeito da floculação (steam flake) do grão de cereais na digestibilidade do amido e outros nutrientes da dieta, na eficiência alimentar, produção e composição do leite}

O efeito do local da digestão de amido na produção de leite é o maior indicador da necessidade de se manipular o local da digestão deste nutriente (Simas, 1997). Vários estudos conduzidos nos últimos anos mostraram os benefícios da utilização de grãos de milho e sorgo floculados na alimentação de vacas leiteiras de alta produção. Theurer et al. (1995) sumarizaram nove estudos de lactação comparando sorgo floculado com sorgo laminado. As vacas alimentadas com sorgo floculado produziram $9 \%$ mais leite, $6 \%$ mais leite corrigido para gordura, $13 \%$ mais proteína do leite e foram $8 \%$ mais eficientes na utilização do alimento quando comparadas com as alimentadas com sorgo laminado. Vários outros trabalhos têm demonstrado os benefícios da floculação do sorgo nos parâmetros produtivos (Nussio et al., 1996 a e b; Santos et al.,1997; Santos et al.,1996).

Moe \& Tyrrell (1976) trabalharam com três formas físicas de processamento de milho (grão inteiro, moído grosso e moído fino) em dietas de vacas de leite e observaram que a medida que o tamanho de partículas diminuiu, a produção de leite e a quantidade total de proteína do leite aumentaram.

Poore et al.(1993) trabalhando com duas fontes de volumosos (feno de alfafa e sua substituição por palha de trigo) e duas fontes de amido com diferentes degradabilidades ruminais (sorgo laminado a seco e sorgo floculado) observaram que a digestibilidade aparente da matéria orgânica no trato total foi maior para os tratamentos com sorgo floculado (68\%) quando comparado com o sorgo laminado (63\%). O mesmo acontecendo com a digestibilidade do amido (98\% e 83\%, respectivamente). Não houve efeito na digestibilidade da proteína bruta e em relação a FDN e FDA houve uma tendência de redução quando o tratamento continha sorgo floculado em relação ao sorgo laminado. 
Aldrich et al. (1993) trabalhando com dois níveis (alto e baixo) de carboidratos não estruturais degradáveis no rúmen (milho alta umidade e milho grão) e proteína degradável no rúmen (farelo soja + farelo de canola e farelo de soja + farinha de sangue ) observaram que a produção de leite não foi afetada pelos tratamentos. $O$ teor de proteína do leite foi maior para o tratamento com alto percentual de carboidrato não estrutural e proteína degradável no rúmen, mas o teor de gordura e quantidade de gordura produzida $(\mathrm{kg} / \mathrm{dia})$, bem como produção de leite corrigida para gordura foram afetados negativamente.

Chen et al. (1994) compararam o efeito da floculação do milho e sorgo, laminação a vapor do milho e laminação a seco do sorgo e observaram que a floculação aumentou a digestibilidade aparente do amido no trato digestivo total, sendo que o benefício foi maior para o sorgo. A floculação também aumentou a produção de leite, leite corrigido para gordura (somente para o sorgo), aumentou a quantidade ( $\mathrm{kg}$ ) de proteína do leite, o teor de proteína do leite (somente para o sorgo). A digestibilidade aparente da matéria seca, FDA e FDN no trato digestivo total foi maior para as dietas com milho floculado a vapor quando comparado com o sorgo laminado a seco.

Mitzener et al. (1994) compararam tipos de processamento físico de milho e sorgo (finamente moído ou laminado) em dietas para vacas em início de lactação, produzindo acima de $33 \mathrm{~kg}$ de leite/dia e concluíram que o sorgo e o milho finamente moídos produziram $6 \%$ mais leite que os grãos laminados, não havendo diferenças na ingestão de matéria seca. As dietas que continham o grão de milho ou sorgo laminado tiveram um maior teor de gordura no leite, quando o tratamento sorgo moído fino apresentou maior teor de proteína no leite que o milho moído fino. A eficiência alimentar foi melhor para os tratamentos com o grão moído fino ( $7,5 \%$ para o sorgo e $5,4 \%$ para o milho).

Chen et al.(1995) trabalhando com vacas de leite (dieta com 33\% volumoso : $67 \%$ concentrado) reportaram que a inclusão na dieta de sorgo floculado em substituição a uma mistura de concentrado contendo milho e cevada laminada, polpa de beterraba e resíduo de trigo não afetou a ingestão de matéria seca, aumentou linearmente a produção de leite e aumentou o teor de proteína do leite. A digestibilidade 
aparente do amido no trato digestivo total não foi afetada pela inclusão de sorgo floculado, entretanto, as digestibilidades da matéria seca, matéria orgânica, proteína bruta, FDN e FDA diminuiram com o aumento na taxa de inclusão do sorgo floculado.

Oliveira et al.(1995) em um ensaio de metabolismo com quatro vacas holandesas canuladas no duodeno proximal, estudaram o efeito do processamento do grão (1- sorgo floculado; 2- sorgo laminado a seco; 3- sorgo laminado+ floculado; 4milho laminado a vapor), os quais perfaziam $43 \%$ em base seca da dieta ( $35 \%$ de volumoso e $65 \%$ de concentrado). A digestibilidade do amido no trato total foi maior para o sorgo floculado quando comparado com o sorgo laminado a seco e sorgo laminado a seco + sorgo floculado $(97,1 \%, 85 \%$ e $88 \%$, respectivamente). Neste trabalho, não houve diferença significativa na digestibilidade do amido entre o sorgo floculado e o milho laminado a vapor.

Knowlton et al. (1996) reportaram um aumento na produção de leite (4\%) e diminuição na perda de peso no início da lactação em vacas alimentadas com milho moído fino comparado com milho moído grosso, devido a um aumento na digestibilidade do amido ( 92 e $85 \%$ no trato total, respectivamente).

Plascencia \& Zinn (1996) trabalhando com quatro vacas primíparas holandesas canuladas no rúmen e duodeno proximal, testaram milho laminado a seco e milho floculado (39,5\% matéria seca da dieta) com diferentes densidades $(390 \mathrm{~g} / \mathrm{l} ; 320 \mathrm{~g} / \mathrm{l}$ e $260 \mathrm{~g} / \mathrm{l})$. Os autores reportaram que a digestibilidade da matéria orgânica no trato digestivo total foi maior para os tratamentos com milho floculado quando comparado com o milho laminado a seco $(72,2 \%$ e $62,7 \%$, respectivamente). Houve efeito linear na digestibilidade da FDN no trato total em relação a densidade do floco, sendo que o milho floculado a $260 \mathrm{~g} / \mathrm{l}$ apresentou a menor digestibilidade. A digestibilidade da proteína bruta no trato total foi maior para os tratamentos com milho floculado quando comparado com o milho laminado a seco (65,4\% e $58,6 \%$, respectivamente). A floculação também aumentou a digestibilidade do amido quando comparada com a laminação a seco ( $96 \%$ e $76,7 \%$, respectivamente). A produção de leite foi maior para os tratamentos com milho floculado quando comparado com o milho laminado a seco $(25,5 \mathrm{~kg} / \mathrm{dia}$ e $22,9 \mathrm{~kg} / \mathrm{dia})$, o mesmo acontecendo com a 
produção de leite corrigida para gordura; neste ponto os autores também encontraram um efeito linear $(\mathrm{P}<0,05)$ em relação ao processamento do grão, ou seja, quanto mais processado o grão menor a produção de leite corrigida para gordura. Em relação a quantidade de proteína do leite produzida $(\mathrm{kg} / \mathrm{dia})$, os tratamentos com milho floculado foram superiores quando comparados com o milho laminado a seco $(0,73 \mathrm{~kg}$ e $0,6 \mathrm{~kg}$, respectivamente). Houve uma menor produção de gordura para o tratamento com milho laminado a seco $(0,84 \mathrm{~kg} / \mathrm{dia})$ em relação aos tratamentos com milho floculado $(0,90 \mathrm{~kg} / \mathrm{dia})$, como também houve efeito linear do processamento do grão sobre a produção de gordura e percentual de gordura do leite, ou seja, quanto maior o processamento menor a produção de gordura.

Joy et al. (1997) trabalharam com vacas canuladas no duodeno proximal, onde as dietas continham $40 \%$ de volumoso e $60 \%$ de concentrado. Os tratamentos eram compostos de milho laminado a seco, milho floculado a $390 \mathrm{~g} / \mathrm{l}$ e milho floculado a $310 \mathrm{~g} / \mathrm{l}$ e a fonte de amido representou um valor fixo de $24 \%$ na matéria seca da dieta. A digestibilidade do amido no trato total foi maior para o milho floculado (390g/l e 310g/l) (85,13\% e 94,4\%, respectivamente) quando comparado com o milho laminado a seco (80\%). A digestibilidade da matéria orgânica no trato total foi maior para o floculado a $310 \mathrm{~g} / \mathrm{l}$ quando comparado com o floculado a $390 \mathrm{~g} / \mathrm{l}$, entretanto, não houve diferença significativa entre o laminado a seco e os tratamentos com milho floculado. A floculação reduziu a digestibilidade da FDN no trato total.

Wilkerson et al. (1997) estudaram o efeito do método de colheita e o método de processamento do milho grão. Os tratamentos foram arranjados em um fatorial $2 \times 2$, sendo milho grão seco ou úmido e tipo de processamento (laminado ou moído em peneira de $6,4 \mathrm{~mm}$ ). As dietas eram compostas de $45,3 \%$ de silagem de alfafa na base seca, $45,3 \%$ de grão de milho e $12,3 \%$ de um suplemento protéico. A inclusão de milho de alta umidade moído aumentou a digestibilidade da MS, MO, PB e carboidratos não fibrosos da dieta. A produção de leite foi $2 \mathrm{~kg} / \mathrm{dia}$ maior para as vacas que se alimentaram de milho de alta umidade quando comparadas com as vacas que se alimentaram de milho grão seco e $2,2 \mathrm{~kg} /$ dia maior para as vacas que se alimentaram com dietas contendo milho moído quando comparado com o milho laminado. A 
produção $(\mathrm{kg} / \mathrm{dia})$ de proteína do leite foi maior no tratamento milho alta umidade e moído.

Lykos et al. (1997) trabalharam com 12 vacas holandesas (sendo 6 canuladas no duodeno e 6 vacas intactas) recebendo dieta completa, variando a taxa de degradação dos carboidratos não estruturais (6,04; 6,98 e 7,94\%hora), com a inclusão de milho de alta umidade em substituição ao milho quebrado. As dietas continham $55 \%$ de volumoso ( 15 a $23 \%$ de silagem de alfafa, 27 a $36 \%$ de silagem de milho e $4 \%$ de feno de alfafa) e $45 \%$ de concentrado. Houve aumento significativo na digestibilidade total da matéria seca, da matéria orgânica e dos carboidratos não estruturais a medida que se aumentou a taxa de degradação de carboidratos não estruturais. As produções de leite e de proteína do leite também foram aumentadas à medida que se aumentou a degradabilidade ruminal dos carboidratos não estruturais.

Yu et al. (1997) comparando milho floculado com milho laminado a vapor, verificaram que o processamento não afetou significativamente a ingestão de matéria seca, entretanto, observou-se um consumo maior de matéria seca para o tratamento com milho laminado (5\%). A produção de leite e a eficiência alimentar (leite corrigido para gordura/ingestão de matéria seca) foram maiores para o tratamento com milho floculado. A floculação também aumentou o teor e a produção de proteína do leite, mas tendeu a reduzir a gordura do leite.

Yu et al. (1998) estudaram o efeito de cinco diferentes tipos de processamento de milho (moído fino $580 \mathrm{~g} / \mathrm{l}$; moído grosso $618 \mathrm{~g} / \mathrm{l}$; milho floculado $309 \mathrm{~g} / 1$; milho floculado $360 \mathrm{~g} / \mathrm{l}$ e milho laminado a vapor $490 \mathrm{~g} / 1$ ) (milho $40 \%$ na matéria seca da dieta) no desempenho lactacional de vacas de leite e na digestibilidade dos nutrientes. Eles concluíram que a ingestão de matéria seca foi menor para o tratamento milho moído fino em relação aos outros tratamentos e a densidade do milho floculado não afetou a ingestão de matéria seca. A média de produção de leite foi 2,5kg/dia maior para as vacas alimentadas com milho floculado $360 \mathrm{~g} / \mathrm{l}$ do que para as vacas alimentadas com milho moído grosso, milho floculado $309 \mathrm{~g} / \mathrm{l}$ e milho laminado a vapor. As vacas alimentadas com milho floculado $360 \mathrm{~g} / \mathrm{l}$ produziram em média $1,6 \mathrm{~kg} / \mathrm{dia}$ a mais que as do tratamento milho moído fino $(37,1 \mathrm{~kg}$ e 35,5 
respectivamente), o que da um diferencial de $4,3 \%$ na produção de leite, embora a diferença não tenha sido significativa estatisticamente; o mesmo acontecendo com a produção de leite corrigida para gordura. As vacas do tratamento milho moído fino tiveram a melhor eficiência alimentar. O percentual de gordura do leite foi menor para o tratamento milho floculado $309 \mathrm{~g} / \mathrm{l}$ quando comparado com milho laminado e moído grosso e a proteína do leite não foi afetada pelos tratamentos. A floculação e a moagem fina aumentaram a digestibilidade do amido no trato total mas tiveram efeito negativo na digestibilidade da fibra.

\subsection{Polpa de citros peletizada como fonte de energia para ruminantes}

\subsubsection{Histórico Geral}

O uso de subprodutos cítricos para alimentação de ruminantes teve início em 1911, nos Estados Unidos. Porém somente a partir de 1934, o processo de secagem foi desenvolvido, principalmente, em virtude do interesse das esmagadoras de laranja (Gohl, 19 73; Wing, 1982). A polpa cítrica é obtida após duas prensagens que reduzem a umidade a $65-75 \%$ e posterior secagem até $90 \%$ de matéria seca, para então ser peletizada e comercializada . Para facilitar o desprendimento da água e reduzir a natureza hidrofilica da pectina, principal carboidrato presente neste alimento, é feita adição de hidróxido ou óxido de cálcio antes das prensagens. Por ser um subproduto da fabricação do suco de laranja, a polpa cítrica peletizada é composta de cascas, bagaço e sementes (Wing, 1982). Desde então, a polpa cítrica peletizada vem sendo utilizada como uma das principais fontes de energia na alimentação de ruminantes no Estado da Flórida (Gohl, 1973). 
Apesar do Brasil ser o principal produtor mundial, com a safra 98-99 estimada em 900 mil a 1 milhão de toneladas segundo Rocha Filho (1998), até meados de 1993 o produto era quase desconhecido para a pecuária nacional. A principal razão residia no fato de que a polpa cítrica peletizada, desde o início da década de 70 era exportada quase que integralmente para a Europa (95-97\% da produção), sendo empregada como ingrediente de ração para bovinos. No entanto, em meados de 1993, o produto sofreu uma queda nas cotações internacionais em virtude de menor demanda, o que obrigou as indústrias esmagadoras a direcionarem parte da produção para o mercado interno (Carvalho, 1995). Apesar do pouco tempo, a polpa de citros peletizada (PCP) consolidou-se e vem conquistando cada vez mais seu espaço no mercado interno não só pelo trabalho de divulgação exercido por alguns técnicos e revistas especializadas, como também pelas qualidades nutricionais deste alimento. Além do fato de que a sua época de produção é extremamente favorável, com a safra sendo iniciada em maio e terminando em janeiro, coincidindo com a entresafra de grãos, como o milho e sorgo. Desta forma o produtor de leite ou corte contam com um importante suplemento energético exatamente nos meses em que o milho atinge cotação máxima.

\subsubsection{Valor nutritivo e características de fermentação ruminal}

A composição bromatológica da polpa de citros peletizada nacional, evidenciada em vários trabalhos, demonstra que a mesma possui ao redor de 85-90\% do valor energético do milho, não sendo, assim como este, uma boa fonte protéica (N.R.C, 1989; Stern \& Ziemer, 1993). Quando comparada com o milho, a polpa de citros peletizada é um material com teor muito baixo de amido em sua composição, com valores entre 0,1 e $0,14 \%$ segundo Deaville et al. (1994). A polpa de citros peletizada deve ser considerada um alimento concentrado energético (FDN entre 20 e $25 \%$ da M.S), porém, apresenta características sob o aspecto de fermentação 
ruminal que a colocam como um produto intermediário entre volumosos e concentrados (Fegeros et al., 1995). Outra característica importante a ser mencionada é o seu alto teor de carboidratos solúveis ao redor de $25 \%$ da matéria seca (Waiman \& Dewey, 1988), enquanto valores de até 35\% foram relatados por de Faria et al. (1972).

Além de possuir alto teor de carboidratos solúveis e parede celular altamente digestível, a polpa cítrica apresenta em sua composição um carboidrato denominado pectina ( $25 \%$ da matéria seca), constituída por polímeros de ácido galacturônico e que faz parte da estrutura da parede celular dos vegetais. A pectina é um carboidrato estrutural quase totalmente (90-100\%) degradável no rúmen (Noceck, 1991; Stern \& Ziemer, 1993), sendo invariavelmente o carboidrato complexo de mais rápida degradação ruminal (Van Soest et al., 1991). Sniffen (1988) observou taxas de degradação ruminal entre 30 e $50 \%$ por hora para a pectina, enquanto o amido de milho não processado a vapor é digerido a uma taxa que varia de 10 a $20 \%$ por hora. Chesson \& Monro (1982) encontraram valores similares de 30 a $45 \%$ por hora de taxa de degradação para a pectina, tendo sua quase completa degradação em 12 ou 18 horas. Este polissacarídio não amídico, presente na polpa de citros peletizada, beterraba, maça ou na alfafa, é um carboidrato prontamente disponível para que haja máxima produção de proteína microbiana no rúmen, o que é fundamental uma vez que na maior parte das dietas a proteína microbiana corresponde a 50-60\% da proteína que chega ao intestino delgado da vaca (Clark et al., 1992). A fermentação da pectina é peculiar, gerando grande quantidade de energia por unidade de tempo, como ocorre com o amido e açúcares, porém com fermentação acética, que caracteriza a celulose e a hemicelulose, reduzindo os riscos de acidose. Além disto a pectina possui elevada capacidade de evitar queda de $\mathrm{pH}$ ruminal através de um mecanismo próprio de tamponamento ruminal (Van Soest, 1987; Van Soest, 1994).

A PCP é caracterizada pela alta digestibilidade da matéria seca. Schultz et al. (1993) estudando a degradabilidade ruminal de diversos subprodutos através da técnica de degradação "in situ", concluíram que a polpa cítrica peletizada é rápida e extensamente degradada no rúmen, sendo superior em degradação quando comparada ao milho laminado. Giardini (1993) cita que em dietas de alta produção, na 
qual o nível de alimentos concentrados é elevado, pode haver deficiência de fibra na dieta e consequentemente causar efeitos deletérios na manutenção da motilidade ruminal e estímulo à ruminação. Substituindo-se parte do amido da dieta por polpa cítrica peletizada, permite-se elevar o nível de fibra na dieta e ainda manter adequada disponibilidade de carboidrato degradável no rúmen. A fração fibrosa da polpa cítrica apresenta elevada digestibilidade ruminal, pois apesar do médio teor de FDA (por volta de $24 \%$ da matéria seca), tem-se baixo teor de lignina (1\%), significando que a quase totalidade da fibra é digerida no rúmen do animal, uma vez que a celulose perfaz ao redor de $23 \%$ da matéria seca da polpa e é altamente digerida pelos microorganimos ruminais (Orskov, 1987 ).

De acordo com Van Soest (1987), a substituição de produtos com alto teor de amido (milho, mandioca) por alimentos com alto teor de pectina gera um efeito desejável em dietas de vacas em lactação. Conforme visto, isto ocorre basicamente pela redução na queda do $\mathrm{pH}$ ruminal devido à fermentação acética em substituição à fermentação láctica e pela capacidade de tamponamento ruminal por causa da pectina. Loggins et al. (1964) e Hentges et al. (1966), também observaram em seus trabalhos que a polpa cítrica contribuiu para a elevação da produção de ácido acético, aumentando a relação acético/propiônico no rúmen. Sendo o ácido acético precursor da gordura do leite, verifica-se a elevação do teor de gordura do leite quando a polpa cítrica é introduzida na dieta. Comparando ainda o farelo cítrico com o milho em dietas para bovinos de corte, Hentges et al. (1966) observaram aumento da relação acético/propiônico com a substituição do milho por polpa.

Schaibly \& Wing (1974) testaram a polpa de citros substituindo a silagem de milho nas percentagens de $0 ; 33 ; 67 ; 100 \%$ em base de matéria seca, em novilhos Jersey e observaram que a digestibilidade da matéria seca e da energia aumentaram até nível de $67 \%$ de substituição por polpa de citros. A proporção molar de ácido acético 1 e 2 horas após a alimentação foi maior para o tratamento com $100 \%$ de substituição quando comparado com os demais tratamentos. Entretanto, não houve diferenças significativas entre os tratamentos 4 horas após alimentação. $\mathrm{O}$ pH mais 
baixo encontrado foi 6,81 e 6,75 para os tratamentos com 67 e $100 \%$ de substituição, respectivamente.

Wing (1975) utilizando novilhos de corte fistulados, testou o efeito da forma física (peletizada ou plana) da polpa cítrica no padrão de fermentação numinal. Todas as dietas continham $33 \%$ de feno de alfafa, $33 \%$ de polpa de citros, $26 \%$ de farelo de soja , $6,5 \%$ de aveia , $0,75 \%$ de sal e $0,75 \%$ de fosfato. $O$ tratamento 1 continha polpa de citros plana. O tratamento 2 continha polpa de citros plana (22\%) e polpa de citros peletizada (11\%), O tratamento 3 continha polpa de citros plana (11\%) e polpa de citros peletizada (22\%) e o tratamento 4 continha polpa de citros peletizada. A porcentagem molar média dos AGVs ruminais para todos os tratamentos foram similares e as percentagens molares médias foram: acetato $67,7 \%$; propiônico $15,5 \%$; butírico $14,2 \%$; valérico $1,0 \%$ e isovalérico $0,8 \%$.

Wing (1982) reportou em sua revisão, que a inclusão de polpa de citros seca até $60 \%$ do concentrado, bem como, sua substituição por milho grão moído em dietas de novilhos, não afetou a digestibilidade da matéria seca, da proteína e da energia ou balanço de ácidos graxos voláteis no rúmen.

Pinzon \& Wing (1976) estudaram o efeito da substituição de milho moído por polpa de citros (peletizada e não peletizada) em dietas para novilhos contendo $33,3 \%$ de bagaço de cana e $66,7 \%$ de concentrado. Os níveis de inclusão de polpa de citros foram $0 \%, 19 \%, 38 \%$ e $55 \%$ da matéria seca da dieta. Foi observado queda no pH ruminal com níveis crescentes de polpa de citros $(6,85 ; 6,65 ; 6,61$ e 6,51$)$ na dieta apesar dos valores estarem todos adequados para a degradação de fibra no rúmen. Os níveis mais altos de inclusão de polpa de citros na dieta tenderam a reduzir o nível de amônia ruminal e reduziram o nível de uréia plasmática, sugerindo uma melhor utilização do nitrogênio a nível de rúmen.

Ben-Gheldalia et al. (1989) compararam vários parâmetros ruminais em dietas com polpa cítrica + farelo de soja ou grão de cevada em ovinos e observaram que a polpa cítrica mesmo sendo alta e rapidamente fermentada no rúmen, criou condições favoráveis para a degradação ruminal de celulose (a parede celular foi $16 \%$ mais digestível), refletidas na maior relação acetato/propionato, maior fluxo de 
nitrogênio ao intestino e maior absorção de nitrogênio pelo intestino em comparação com a cevada.

Em experimento conduzido por Valk et al. (1990), as perdas de amônia no rúmen foram menores em dieta com polpa de beterraba (semelhante a polpa de citros) em comparação ao milho. Eles sugeriram que os microorganismos do rúmen capturaram mais amônia proveniente da degradação da proteína da forragem, do que quando se utilizou o milho. Mc.Cullough (1995), sugeriu que a utilização do nitrogênio da dieta pode ser alto em dietas contendo alimentos ricos em pectina, como a polpa cítrica e a de beterraba. A concentração no sangue, de nitrogênio na forma de uréia é um indicativo da existência de amônia não aproveitável no rúmen, sendo eliminada como uréia pela urina. Nas dietas com alto teor de polpa de citros a uréia sangüínea foi significativamente menor do que na dieta com milho. Partindo da informação de que os teores de amônia no rúmen eram iguais, pode-se deduzir que houve maior retenção e consequentemente, utilização mais eficiente da proteína pelos animais que receberam a polpa cítrica. Houve também uma redução na concentração de ácido propiônico, elevando a relação acetato/ propionato.

Rocha Filho (1998) trabalhando com vacas canuladas no rúmen, estudou a substituição da silagem de milho por diferentes quantidades de polpa de citros peletizada, milho ou combinação de milho + polpa em alguns parâmetros ruminais. Os resultados de produção total de ácidos graxos voláteis, $\mathrm{pH}$ ruminal, amônia ruminal e uréia sanguínea não foram diferentes entre os tratamentos. A inclusão de polpa de citros aumentou a proporção molar de acetato e diminuiu a proporção molar de propionato em relação à dieta contendo milho. 


\subsubsection{Efeito da utilização da polpa de citros sobre a digestibilidade de nutrientes, eficiência alimentar, prod ução e composição do leite}

Drude et al. (1971) trabalharam com vacas de alta produção cujas dietas continham (\% matéria seca) $60 \%$ de concentrado e $40 \%$ de volumoso (silagem de milho + alfafa peletizada; silagem de milho + polpa de citros; alfafa peletizada + polpa de citros e alfafa peletizada + casca de algodão). Foi observado que quando a polpa de citros ou a alfafa entraram na dieta a ingestão de matéria seca foi similar entre os dois tratamentos. Entretanto, houve uma maior produção de leite corrigido para gordura e um maior percentual de gordura no leite quando cada um desses alimentos foi combinado com silagem de milho. A polpa de citros suportou maiores ingestões de matéria seca, percentual de gordura no leite e maior produção de leite corrigido para gordura quando combinada com silagem de milho do que com alfafa peletizada.

Lucci et al. (1975), substituíram até $100 \%$ do milho rolão em dietas de vacas em lactação de baixa produção, chegando a fornecer $67 \%$ do concentrado na forma de polpa de citros. Os autores obtiveram aumento do teor de gordura e da produção de leite corrigida para gordura (12,6 para $13,2 \mathrm{~kg}$ vaca/dia). A conclusão foi que a polpa de citros pode substituir totalmente o milho desintegrado em dieta de vacas em lactação, sendo a extensão desta substituição apenas função do preço dos ingredientes.

Van Horn (1975) comparou a inclusão de polpa de citros em percentuais de 8 e $43 \%$ como componentes de dietas completas. A dieta mais alta em polpa de citros resultou em maior teor de gordura do leite $(4,16 \%)$ contra $3,57 \%$ para dieta contendo $8 \%$ de polpa de citros. Os parâmetros de fermentação neste experimento não foram mensurados, entretanto, os autores argumentam que parece evidente o papel da polpa de citros na manutenção da gordura do leite, devido à maior produção de acetato.

Wickes \& Bartsch (1978) trabalharam com quatro grupos de nove vacas holandesas cada um, as quais recebiam $67 \%$ dos requerimentos de energia 
metabolizável através de ryegrass e os $33 \%$ restantes através de misturas de cevada $(3,9$; $3,2 ; 2,0 ;$ e $0,0 \mathrm{~kg})$ e polpa cítrica seca ( 0,$0 ; 0,7 ; 1,9 ;$ e $3,4 \mathrm{~kg})$. Os autores observaram que as vacas que receberam 1,9 e 3,4 $\mathrm{kg}$ de polpa de citros produziram menos proteína no leite e a produção de leite foi maior no tratamento com $1,9 \mathrm{~kg}$ de polpa $(15,2$ $\mathrm{kg} / \mathrm{leite})$.

Sutton et al.(1987), trabalharam com concentrados amiláceos (cevada, trigo, mandioca) e concentrados fibrosos ( polpa de citros e polpa de beterraba) para vacas em lactação, em proporções de 60 ou $80 \%$ da dieta. Com concentrados amiláceos, quando utilizados em níveis altos na dieta, houve um aumento de $22 \%$ na produção de leite, porém, uma severa depressão na concentração de gordura. A queda na concentração de gordura no leite foi menos severa para os concentrados fibrosos ao nível de $80 \%$ de concentrado na dieta.

Belibasakis et al. (1996) trabalharam com 20 vacas holandesas multíparas (80-130 dias pós parto) cujas dietas continham: 1) 50\% de silagem de milho $+20 \%$ de polpa cítrica seca $+30 \%$ de concentrado ou; 2) $50 \%$ de silagem de milho + $15 \%$ de polpa de beterraba seca $+8 \%$ de milho grão $+27 \%$ de concentrado (controle) e observaram que a ingestão matéria seca, energia metabolizável e proteína, como também, produção de leite, \% e produção de proteína do leite e lactose do leite não foram afetados pelos tratamentos. Entretanto, o tratamento com a polpa de citros seca aumentou o percentual de gordura do leite e a produção de leite corrigida para gordura $(4,48 \%$ vs. $4,12 \%$ e 1,06 vs. $0,95 \mathrm{~kg} / \mathrm{dia}$, respectivamente). Nenhuma efeito significativo foi observado nas concentrações plasmáticas de glucose ou uréia. 


\section{MATERIAL E MÉTODOS}

\subsection{Animais e instalações experimentais}

$\mathrm{Na}$ condução do trabalho foram utilizadas quatro (4) vacas da raça holandesa preto e branco. Todas as vacas eram lactantes (média de 120 dias de lactação), se encontravam em sua segunda lactação e foram submetidas a intervenções cirúrgicas para implantação de duas cânulas, sendo, uma localizada no rúmen e outra na parte proximal do duodeno. Os animais tiveram um período de trinta dias de cuidados pós-operatórios.

Os animais receberam tratamento prévio para o combate a endo e ectoparasitas. Todos os períodos experimentais foram conduzidos nas instalações do Centro de Pesquisa em Nutrição Animal do Departamento de Produção Animal ESALQ/USP, onde os animais foram alojados em baias $(2,5 \times 1,10 \mathrm{~m})$, tipo "tie stall," providas de comedouros individuais e bebedouros automáticos . 


\subsection{Tratamentos}

Foi utilizado um delineamento quadrado latino $4 \times 4$ (quatro animais $\mathrm{x}$ quatro períodos). Os quatro tratamentos tinham como volumoso a silagem de milho. Foram testados dois tipos de processamento de grão de milho e a substituição parcial dos mesmos por polpa de citros peletizada. Os tratamentos testados foram: 1) Milho moído grosso (MMG) (655 g/l); 2) Milho floculado (MF) (360 g/l); 3) Milho moído grosso (MMG) (655 g/l) + Polpa de citros (PCP); 4) Milho floculado (MF) (360 $\mathrm{g} / \mathrm{l})+$ Polpa de citros (PCP). A Tabela 1 mostra a composição das dietas:

Tabela 1. Composição das dietas experimentais em (\%) da matéria seca.

\begin{tabular}{|c|c|c|c|c|}
\hline $\begin{array}{c}\text { Dietas } \\
\text { Experimentais }\end{array}$ & $\begin{array}{c}\text { Milho } \\
\text { MoídoGrosso } \\
(\mathrm{MMG})(655 \mathrm{gll})\end{array}$ & $\begin{array}{c}\text { Milho } \\
\text { Floculado } \\
(\mathrm{MF})(360 \mathrm{~g} \backslash \mathrm{l})\end{array}$ & $\begin{array}{c}\text { MMG } \\
+ \\
\text { PCP }\end{array}$ & $\begin{array}{c}\text { MF } \\
+ \\
\text { PCP }\end{array}$ \\
\hline Ingredientes & & & & \\
\hline $\begin{array}{l}\text { Silagem de } \\
\text { milho }\end{array}$ & 50,20 & 49,83 & 50,00 & 49,80 \\
\hline Milho & 28,52 & 29,05 & 13,72 & 14,01 \\
\hline $\mathrm{PCP}^{1}$ & - & $=$ & 14,06 & 14,00 \\
\hline Farelo de soja & 16,70 & 16,57 & 17,64 & 17,58 \\
\hline Supl.Mineral $^{2}$ & 3,48 & 3,46 & 3,48 & 3,51 \\
\hline Uréia & 1,10 & 1,09 & 1,10 & 1,10 \\
\hline
\end{tabular}

${ }^{1} \mathrm{PCP}=$ polpa de citros peletizada.

${ }^{2}$ Suplemento Mineral : 16,9\% Ca; 4,2\% P; 5,4\% Na; 2,7\% Mg; 1,7\% S; 1193 ppm Zn; 346 ppm $\mathrm{Cu} ; 38,5 \mathrm{Co} ; 30,8 \mathrm{ppm}$ I; 15,4 ppm Se e 23\% de bicarbonato de sódio. 
O alimento concentrado foi misturado previamente para cada período em misturador vertical (marca Lucato, capacidade $500 \mathrm{~kg}$ ). Por ocasião do fornecimento da alimentação, eram pesadas as quantidades de volumoso e concentrado para posterior combinação, objetivando a obtenção da ração completa de cada animal. O fornecimento da ração completa foi realizado duas vezes ao dia (6:00 e 18:00 horas), permitindo uma sobra de 5 a $10 \%$ para evitar limitação de consumo por parte dos animais.

\subsubsection{Processa mento e determinação do ta manho de partículas (granulometria) do} grão de milho

O procedimento utilizado para obtenção da forma fisica do milho moído grosso, foi a trituração em um moinho de martelos, com a retirada de duas facas e de todos os seis conjuntos de martelo do moinho. Já para o milho floculado a obtenção da forma física se deu através da passagem do grão (após exposição ao vapor por 30 minutos) por rolos alto ajustáveis para obtenção do floco. A densidade do milho moído grosso ou floculado foi medida após o processamento através da mensuração do peso por unidade de volume utilizando uma proveta de vidro graduada Pyrex contendo 1 litro. O milho moído grosso apresentou densidade de $655 \mathrm{~g} / \mathrm{litro}$ e o milho floculado 360g/litro. Para determinação do tamanho médio de partículas das formas físicas do milho moído grosso ou floculado, utilizou-se a técnica de peneiras descrita por YU et al.(1998), conforme a Tabela 2. 
Tabela 2. Tamanho de partículas e tamanho médio de partículas do milho processado.

Tamanho dos furos da peneira (mm)

\begin{tabular}{|c|c|c|c|c|c|c|c|c|c|}
\hline \multicolumn{10}{|c|}{ Tamanho dos furos da peneira (mm) } \\
\hline $\begin{array}{l}\text { Tipo } \\
\text { de } \\
\text { grazo }^{1}\end{array}$ & 4,00 & 2,00 & 1,00 & 0,85 & 0,60 & 0,43 & 0,25 & P.R.P ${ }^{2}$ & M.T. $P^{3}$ \\
\hline \multicolumn{10}{|c|}{$\%$ retido na peneira } \\
\hline MMG & 21,80 & 53,8 & 14,4 & 2,2 & 2,7 & 1,2 & 1,7 & 2,2 & 4,27 \\
\hline MF & 72,3 & 24,6 & 1,9 & 0,2 & 0,3 & 0,1 & 0,1 & 0,5 & 5,09 \\
\hline
\end{tabular}

${ }^{2} \mathrm{MMG}=$ milho moído grosso(655 g/L); MF = milho floculado ( $\left.360 \mathrm{~g} / \mathrm{L}\right)$

${ }^{2}$ P.R.P $=\%$ partículas retidas no fundo do prato.

${ }^{3}$ M.T.P = média do tamanho de partículas. Foi calculada, assumindo-se que o milho retido na peneira de $4,00 \mathrm{~mm}$ tem o tamanho de partículas médio de $6 \mathrm{~mm}$, o qual foi multiplicado pela percentagem retida na peneira $4,00 \mathrm{~mm}$. Este valor fôi somado ao resultado das médias entre as peneiras maiores e menores, vezes o percentual retido na peneira menor (ex: MMG $4 \mathrm{~mm}+2 \mathrm{~mm} \div 2=3$, que multiplicado por $0,538=1,59 \mathrm{e}$, assim sucessivamente). As partículas que passaram pelo peneira de crivo $0,25 \mathrm{~mm}$, foram consideradas como tendo $0,12 \mathrm{~mm}$.

\subsection{Período experimental}

O período experimental teve duração de 56 dias, subdivididos em 4 sub-períodos de 14 dias cada. Os primeiros 10 dias de cada sub-período foram usados para adaptação dos animais aos tratamentos e os quatro dias restantes para as coletas de conteúdo duodenal, fluído ruminal, plasma sangüíneo, leite e amostras do alimento oferecido ao animal e do alimento recusado pelo animal e para as medições de consumo de alimento e produção de leite. 


\subsubsection{Coleta de dados referentes ao consumo de matéria seca por parte dos animais}

Os dados de consumo de matéria seca (M.S) por animal/dia foram obtidos arravés da diferença entre quantidade de M.S fornecida e a da sobra. Durante os quatro dias de coleta de cada sub-período, antes do fornecimento da ração completa, as sobras do alimento e o alimento a ser fornecido a cada animal foram amostrados e pesados. No caso das sobras, foram retiradas dos cochos e posteriormente pesadas. Uma alíquota de aproximadamente 500 gramas/dia foi retirada do oferecido e das sobras e composta até o final do sub-período, perfazendo um total de aproximadamente $2 \mathrm{~kg}$ de sobra por vaca por sub-período. As amostras foram conservadas e congeladas a $-10^{\circ} \mathrm{C}$ até serem descongeladas e secadas em estufas de ventilação forçada $\left(55-60^{\circ} \mathrm{C}\right)$ por 72 horas para determinação de matéria seca de acordo com A.O.A.C (1990).

\subsubsection{Análises bromatológicas das dietas e do recusado}

As dietas fornecidas e as sobras, foram amostradas diariamente durante 4 dias de coleta de cada sub-período e compostas por vaca e sub-período. As amostras foram secas em estufas de ventilação forçada $\left(55-60{ }^{\circ} \mathrm{C}\right)$ por 72 horas de acordo com A.O.A.C (1990) e moídos em moinhos tipo Wiley providos de peneiras de $1 \mathrm{~mm}$ e analisadas para matéria seca $\left(105^{\circ} \mathrm{C}\right.$ durante $\left.15 \mathrm{~h}\right)$, matéria orgânica e proteína bruta de acordo com o A.O.A.C (1990), amido de acordo com Poore et al.(1989) e fibra em detergente neutro e fibra em detergente ácido de acordo com Van Soest (1991). Para os dois tipos de processamento de milho, moído grosso e floculado, foram feitas as respectivas taxas de hidrólise "in vitro" do amido de acordo com Poore et al. (1989). 


\subsubsection{Coleta do fluído ruminal para determinação de $\mathrm{AGVs}, \mathrm{N}-\mathrm{NH}_{3}$ e pH ruminal}

As amostras do fluído ruminal foram coletadas no último dia de coleta de cada sub-período, com intervalos de 2 horas entre cada coleta. Os tempos de coletas foram representados pelos tempos zero, antes do primeiro fornecimento das dietas pela manhã e assim sucessivamente até completar 24 horas. As amostras de conteúdo ruminal foram coletadas de quatro pontos distintos do rúmen após prévia homogeneização do conteúdo no interior do rúmen, filtradas em quatro camadas de tecido de algodão (fraldas) obtendo-se desta forma aproximadamente $400 \mathrm{ml}$ de filtrado (fluído ruminal). Destes foram retiradas três alíquotas: a) a primeira alíquota de $300 \mathrm{ml}$ foi transferida para um becker para determinação do $\mathrm{pH}$ ruminal. Os valores de $\mathrm{pH}$ do fluído ruminal foram determinados após leitura direta em um potenciômetro digital da Digimed, modelo TE-902 ; b) a segunda aliquota de $50 \mathrm{ml}$ foi acondicionada em frasco plástico e congelada a $-10{ }^{\circ} \mathrm{C}$ para posterior análise de $\mathrm{N}-\mathrm{NH}$. Após o descongelamento as amostras foram centrifugadas a $11.000 \mathrm{~g}$ a $4^{\circ} \mathrm{C}$, durante 20 minutos e uma alíquota de $4 \mathrm{ml}$ foi transferida para um tubo de vidro para posterior análise de acordo com o método colorimétrico descrito por Chaney \& Marbach (1962) e adaptado para ser usado em placas de microtítulo e posterior leitura em aparelho do tipo Elisa Reader (absorvância de 550 nanômetros), que apresenta os resultados em $\mathrm{mg} / \mathrm{dl}$; e) uma terceira alíquota de $50 \mathrm{ml}$ foi acondicionada em frasco plástico e congelada a $-10{ }^{\circ} \mathrm{C}$ para posterior análise de $\mathrm{AGVs}$. Após o descongelamento as amostras foram centrifugadas a $11.000 \mathrm{~g} \mathrm{a} 4^{\circ} \mathrm{C}$, durante 20 minutos e uma alíquota de 4 $\mathrm{ml}$ foi utilizada para análise de AGVs de acordo com Palmquist \& Conrad (1971b), utilizando um cromatógrafo líquido gasoso (CLG) Hewlett Packard 5890, Series II ( Hewlett- Packard Company, Avondale, PA) equipado com HP Integrador (HewlettPackard Company, Avondale, PA ). O padrão interno foi ácido 2- etilbutírico e o nitrogênio foi o gás de arraste. A temperatura do injetor, detector e coluna foram 150 , 190 e $115^{\circ} \mathrm{C}$, respectivamente. 


\subsubsection{Coleta de conteúdo duodenal para determinação da digestibilidade de nutrientes e fluxo de proteína microbiana.}

Durante os quatro dias de coleta de cada sub-período, as amostras de conteúdo duodenal foram coletadas a cada 4 horas $(250 \mathrm{ml})$, sempre adiantando 1 hora por dia, de modo a simular amostras obtidas a cada hora de um período de 24 horas. As coletas de conteúdo duodenal para confecção do pelete de bactérias ruminais para posterior determinação do fluxo de proteína microbiana, foram realizadas em apenas 1 dia, onde foram coletados $500 \mathrm{ml}$ a cada 4 horas, batidas em liquidificadores de alta rotação, posteriormente coadas em fraldas de algodão descartáveis e centrifugados a $17.000 \mathrm{~g}$ por 20 minutos. As amostras do duodeno foram compostas por vaca, período e posteriormente congeladas a $-10{ }^{\circ} \mathrm{C}$ para posterior análise de aminoácidos totais de acordo com A.O.A.C (1990).

\subsubsection{Coleta de fezes para determinação da digestibilidade aparente do trato total}

Durante os 4 dias do período de coleta, amostras de fezes foram coletadas a intervalos de 8 horas, adiantando-se 1 hora por dia, de modo a simular amostras obtidas a cada hora de um período de 24 horas. As amostras de fezes foram compostas por vaca, período e congeladas a $-10^{\circ} \mathrm{C}$ para posterior análise de lignina e cromo, usados como marcadores. $\mathrm{O}$ óxido de cromo foi colocado no rúmen das vacas duas vezes (sendo 10 gramas de cada vez) ao dia durante os 14 dias de cada sub-período. A digestibilidade aparente da matéria seca e demais nutrientes foi calculada da seguinte forma: 


\author{
Digestibilidade do nutriente(\%) \\ $=100-\left(100 \times \frac{\% \text { do marcador no alimento }}{\% \text { do marcador nas fezes }} \times \frac{\% \text { do nutriente nas fezes })}{\% \text { do nutriente no alimento }}\right.$
}

\title{
3.3.6 Coleta de sangue para determinação de glucose e uréia plasmática
}

Amostras de sangue foram coletadas da veia ou artéria coccígea, em tubos de ensaio a vácuo, contendo oxalato de potássio e fluoreto de sódio como antiglucolítico. As amostras de sangue foram centrifugadas a $3000 \mathrm{xg}$ por aproximadamente 15 minutos a temperatura de $4{ }^{\circ} \mathrm{C}$ para extração do plasma sanguíneo, o qual foi congelado a $-10^{\circ} \mathrm{C}$ para posterior análise. As coletas de sangue foram realizadas no último dia de cada período para determinação dos níveis de uréia plasmática, de acordo com Chaney e Marbach (1962) e glucose plasmática pelo método da glucose oxidase descrito por Tietz (1982). Os tempos de coleta foram os seguintes: tempo zero (antes da alimentação matutina) e três, seis e nove horas após a alimentação matutina. Os dois métodos foram adaptados para serem utilizados em placas de microtítulo e posterior leitura em aparelho do tipo Elisa Reader BIO RAD (absorvância de 550 nanômetros), que apresenta os resultados em mg/dl. 


\subsubsection{Avaliação da produção e composição do leite}

As vacas foram ordenhadas duas vezes ao dia e a produção de leite registrada diariamente, durante o período de 4 dias de coleta de cada sub-período. Amostras de leite foram coletadas duas vezes ao dia (manhã e tarde) durante os quatro dias de coleta de cada sub-período, compostas por dia e preservadas com 2-bromo-2nitropropano-1-3-diol sob refrigeração $\left(6{ }^{\circ} \mathrm{C}\right)$ por um dia, para posterior análise de proteína, gordura e sólidos totais utilizando um infrared analyser do Laboratório de Análises de Leite/ Departamento de Produção Animal da ESALQ/USP.

\subsection{Análise estatística}

O experimento foi conduzido segundo o arranjo fatorial $2 \times 2$ (dois tipos de processamento $\mathrm{x}$ inclusão ou não de polpa), no delineamento Quadrado Latino $4 \times 4$ (quatro animais $\times$ quatro períodos), adotando-se para análise estatística o procedimento GLM do programa estatístico SAS (1991). O quadro de análise de variância é mostrado na Tabela 3. 
Tabela 3. Quadro esquemático de análise de variância para o ensaio de digestibilidade e produção :

\begin{tabular}{lc}
\hline \multicolumn{1}{c}{ Causas de Variação } & Graus de liberdade \\
\hline Animal & 3 \\
Período & 3 \\
Tipo de processamento do grão & 1 \\
Inclusão ou não de polpa de citros & 1 \\
Tipo de processamento x polpa & 1 \\
Resíduo & 6 \\
\hline TOTAL & $\mathbf{1 5}$ \\
\hline
\end{tabular}

As variáveis $\mathrm{pH}, \mathrm{AGVS}, \mathrm{N}-\mathrm{NH} 3$, uréia e glucose plasmática foram analisadas estatisticamente como parcelas sub-divididas no tempo. Os efeitos de tratamento, animal e período foram testados com relação às parcelas. A interação horário de coleta $\mathrm{x}$ tratamentos foi testada com relação às sub-parcelas. $\mathrm{O}$ quadro de análise de variância é mostrado na Tabela 4. 
Tabela 4. Quadro esquemático de análise de variância para pH, AGVS, N-NH3 .

\begin{tabular}{lc|}
\hline \multicolumn{1}{c}{ Causas de variação } & Graus de liberdade \\
\hline Animal & 3 \\
Período & 3 \\
Tipo de processamento do grão & 1 \\
Inclusão ou não de polpa de citros & 1 \\
Tipo de processamento x polpa & 1 \\
Resíduo A & 6 \\
\hline Parcelas & $\mathbf{1 5}$ \\
\hline Horário & 11 \\
Tipo de processamento do grão & 11 \\
Inclusão ou não de polpa de citros & 11 \\
Tipo de processamento x polpa & 11 \\
Resíduo B & 132 \\
\hline Sub-parcelas & $\mathbf{1 9 1}$ \\
\hline
\end{tabular}

As diferenças entre os tratamentos para as diversas variáveis avaliadas foram verificadas através do teste $t$ (Student), considerando $5 \%(\mathrm{P}<0,05)$ como nível de significância e até $15 \%$ como tendência $(\mathrm{P}<0,15)$. 


\section{RESULTADOS E DISCUSSÃO}

\subsection{Composição dos alimentos utilizados}

As Tabelas 5 e 6 contém as análises químicas dos alimentos utilizados e a composição de nutrientes das dietas, respectivamente.

Tabela 5. Composição química dos alimentos.

\begin{tabular}{llllllll}
\hline Fração & Unidade & MF $^{2}$ & MM $^{3}$ & POLPA & F. Soja & Uréia & Silag $^{2}$ \\
\hline MS & $\% \mathrm{MS}$ & 89,67 & 87,48 & 88,88 & 89,97 & 98,00 & 32,4 \\
$\mathrm{MO}$ & $\% \mathrm{MS}$ & 98,77 & 98,89 & 94,09 & 93,55 & & 95,9 \\
$\mathrm{~Pb}$ & $\% \mathrm{MS}$ & 8,75 & 8,54 & 6,07 & 49,94 & 281 & 7,12 \\
Amido & $\% \mathrm{MS}$ & 73,45 & 74,43 & 0,5 & 6,017 & & 26,9 \\
FDN & $\% \mathrm{MS}$ & 10,70 & 10,62 & 24,06 & 13,89 & & 47,8 \\
FDA & $\% \mathrm{MS}$ & 3,55 & 3,7 & 19,27 & 11,37 & & 27,5 \\
\hline
\end{tabular}

Nutrientes : MS = matéria seca; $\mathrm{MO}=$ matéria orgânica; $\mathrm{PB}=$ proteína bruta; FDN = fibra em detergente neutro; $F D A=$ fibra em detergente ácido.

${ }^{2} \mathrm{MF}=$ milho floculado $360 \mathrm{~g} /$ /itro; $;{ }^{3} \mathrm{MMG}=$ milho moído grosso $655 \mathrm{~g} / \mathrm{litro} ;{ }^{4} \mathrm{~F}$.Soja = farelo de soja;

${ }^{5}$ Silag $=$ silagem de milho. 
Tabela 6. Composição de nutrientes das dietas.

\begin{tabular}{ccccc}
\hline NUTRIENTES $^{1}$ & MF & $\begin{array}{c}\text { Dietas }^{2} \\
\text { MMG }\end{array}$ & MFP & MMP \\
\hline MO \% & 92,66 & 92,65 & 91,96 & 91,96 \\
PB \% & 17,44 & 17,44 & 17,50 & 17,50 \\
Amido \% & 36,0 & 35,48 & 25,10 & 24,80 \\
FDN \% & 29,20 & 29,36 & 31,12 & 31,20 \\
FDA \% & 16,65 & 16,80 & 18,92 & 19,00
\end{tabular}

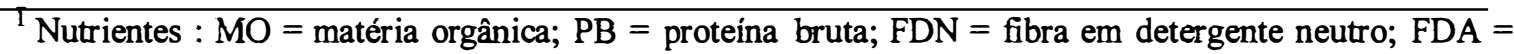
fibra em detergente ácido.

${ }^{2}$ Dietas $=\mathrm{MF}=$ milho floculado $360 \mathrm{~g} /$ litro; $\mathrm{MMG}=$ milho moído grosso $655 \mathrm{~g} /$ litro; MFP = milho floculado $360 \mathrm{~g} /$ litro + polpa de citros peletizada; $\mathrm{MMP}=$ milho moído grosso $655 \mathrm{~g} / \mathrm{litro}+$ polpa de citros peletizada.

\subsubsection{Milho floculado e Milho moído grosso}

Os teores de proteína bruta do milho floculado $(8,75 \%)$ e do milho moído grosso $(8,54 \%)$, foram menores $10 \%$, que os valores do N.R.C (1989). As análises do teor de proteína bruta feitas no Laboratório de Bromatologia do Departamento de Produção Animal nos últimos anos têm mostrado valores semelhantes ao encontrado neste trabalho. Os teores de amido do milho floculado $(73,45 \%)$ e milho moído grosso (74,43\%), estão dentro da média de $72 \%$ citado por Huntington (1997) e Joy et al. (1997). Os teores de FDN e FDA para o milho floculado $(10,7 \%$ e $3,55 \%)$ e para o milho moído grosso $(10,62 \%$ e $3,7 \%)$ estão próximos aos valores encontrados na tabela de composição de alimentos do N.R.C (1989). 


\subsubsection{Polpa de citros peletizada}

O teor médio de proteína bruta da polpa de citros peletizada (5,91\%), FDA (19,27\%) e FDN (24,06\%) estão próximos aos valores indicados por Carvalho $(1995 ; 1998)$. Vale ressaltar que a análise de FDN e FDA teve que ser feita sequencialmente, pois a pectina contida na polpa de citros peletizada é solubilizada em detergente neutro mas não em detergente ácido (Hall, 1995). Desta forma, se a análise não for sequencial, há superestimativa do valor de FDA, que fica maior que o de FDN. Avaliando os registros de análises do Laboratório de Bromatologia do Departamento de Produção Animal, percebe-se que isto de fato tem ocorrido.

Em relação ao teor de amido da polpa, o valor médio de 11,5\% na matéria seca obtido neste trabalho foi muito alto e bem superior ao encontrado na literatura. Wainman \& Dewey (1988), por sua vez, mencionaram valores entre 0,4 a $0,5 \%$. Mesmo considerando os valores de $11 \%$ de amido na MS, pode-se inferir que a polpa de citros quando comparada com o milho, é um suplemento baixo em amido.

Neste trabalho, foram considerados teores de $0,5 \%$ de amido, o que representa um valor mais real (baseado em dados de literatura) deste nutriente para este alimento estudado.

\subsubsection{Farelo de Soja}

Os teores de proteína bruta (49,94\%), amido (6\%), FDN (13,89\%) e FDA (11,37\%), estão próximos aos valores da tabela do N.R.C (1989). 


\subsubsection{Silagem de Milho}

O teor de proteína bruta da silagem de milho de 7,12\%, foi menor que os dados encontrados na tabela de composição de alimentos do N.R.C (1989), de $8,10 \%$. As análises do teor de proteína bruta feitas no Laboratório de Bromatologia do Departamento de Produção Animal têm mostrado valores semelhantes aos encontrados neste trabalho. O teor médio de amido de $26,96 \%$, está dentro da média encontrada na literatura, assim como os teores médios de FDN e FDA, 47,80 e 27,57, estão próximos aos valores encontrados na tabela de composição de alimentos do N.R.C (1989).

\subsection{Taxa de hidrólise enzimática do amido}

O amido do milho floculado apresentou maiores taxas de hidrólise "in vitro", quando comparado com o milho moído grosso, conforme tem sido reportado na literatura (Chen et al., 1995; Joy et al.,1997; Plascencia et al., 1996; YU et al.,1998). O percentual total de amido hidrolisado (37\%) para o milho moído grosso, se assemelha ao valor (34\%) encontrado por YU et al. (1998); entretanto, o percentual de amido hidrolisado para o milho floculado a $360 \mathrm{~g} / \mathrm{l}$ no presente trabalho $(83 \%)$, é bem superior ao encontrado pelo mesmo autor (60\%), o que pode ser um indício de que o processo de floculação provavelmente foi mais intenso para o milho utilizado em nosso trabalho, como mostra a Figura 1. 




Figura 1. Taxa de hidrólise "in vitro"do amido.

\subsection{Fluxo de proteína microbiana e digestibilidade aparente de nutrientes}

Vale ressaltar que o óxido de cromo produziu valores inconsistentes de digestibilidade aparente tanto ruminal quanto no trato total. Portanto utilizou-se a lignina como marcador para os cálculos da digestibilidade aparente no trato digestivo total. O fluxo de proteína microbiana, como também, o perfil de aminoácidos totais (g/dia) não foi possível de ser determinado pois os dois marcadores (óxido de cromo e lignina) utilizados para se estimar a digestibilidade aparente ruminal da matéria seca não apresentaram valores consistentes, sendo alguns até negativos. 


\subsection{Consumo e digestibilidade aparente de nutrientes}

\subsubsection{Matéria Seca e Matéria Orgânica}

Os consumos médios e digestibilidades aparentes da matéria seca (MS) e matéria orgânica (MO) no trato digestivo total, constam na Tabela 7.

Tabela 7. Efeito dos ratamentos sobre o consumo e digestibilidade aparente da matéria seca (MS) e matéria orgânica (MO) no trato digestivo total.

\begin{tabular}{|c|c|c|c|c|c|c|c|c|}
\hline \multirow[b]{2}{*}{ Item $^{1}$} & \multicolumn{4}{|c|}{ Tratamentos $^{2}$} & \multirow[b]{2}{*}{$\mathrm{EPM}^{4}$} & \multicolumn{3}{|c|}{ Efeito $^{3}$} \\
\hline & MF & MMG & MFP & MMP & & PR & PP & PR X PP \\
\hline & & & & & & & $\mathrm{P}<$ & \\
\hline $\mathrm{CMS} / \mathrm{Kg} / \mathrm{d}$ & $19,00^{\mathrm{a}}$ & $19,94^{\mathrm{a}}$ & $18,86^{\mathrm{a}}$ & $19,67^{\mathrm{a}}$ & 0,52 & 0,14 & 0,69 & 0,91 \\
\hline DMSTT/ Kg /d & $13,01^{\mathrm{a}}$ & $11,57^{\mathrm{a}}$ & $13,62^{\mathrm{a}}$ & $12,70^{\mathrm{a}}$ & 0,85 & 0,21 & 0,35 & 0,77 \\
\hline DMSTT/ \% & $68,50^{\mathrm{ab}}$ & $57,80^{b}$ & $72,31^{a}$ & $65,25^{\mathrm{ab}}$ & 3,0 & 0,03 & 0,13 & 0,59 \\
\hline $\mathrm{CMO} / \mathrm{Kg} / \mathrm{d}$ & $17,61^{a}$ & $18,47^{\mathrm{a}}$ & $17,34^{\mathrm{a}}$ & $18,09^{\mathrm{a}}$ & 0,47 & 0,14 & 0,51 & 0,90 \\
\hline DMOTT/ Kg/d & $12,24^{\mathrm{a}}$ & $10,87^{\mathrm{a}}$ & $12,70^{\mathrm{a}}$ & $11,70^{\mathrm{a}}$ & 0,8 & 0,18 & 0,44 & 0,81 \\
\hline DMOTT/\% & $69,51^{\mathrm{ab}}$ & $58,55^{b}$ & $73,30^{\mathrm{a}}$ & $65,00^{\mathrm{ab}}$ & 3,1 & 0,03 & 0,13 & 0,59 \\
\hline
\end{tabular}

\footnotetext{
Item : CMS = consumo de matéria seca; DMSTT = digestibilidade aparente da matéria seca no trato digestivo total; $\mathrm{CMO}=$ consumo de matéria orgânica; DMOTT = digestibilidade aparente da matéria orgânica no trato digestivo total.

${ }^{2}$ Tratamentos: MF = milho floculado $360 \mathrm{~g} / \mathrm{litro}$; MM $=$ milho moído grosso $655 \mathrm{~g} / \mathrm{litro}$; MFP = milho floculado + polpa; $\mathrm{MMP}=$ milho moído + polpa

${ }^{3}$ Efeito $: \mathrm{PR}=$ Tipo de processamento do grão; $\mathrm{PP}=$ Polpa de citros peletizada; $\mathrm{PR} \times \mathrm{PP}=$ processamento $\mathrm{x}$ Polpa.

${ }^{4}$ Erro padrão da média.

${ }^{a b}$ Médias seguidas de letras distintas, na mesma linha, diferem entre si pelo teste de $t$ (Student) a $5 \%$ de probabilidade.
} 
A inclusão parcial de polpa de citros peletizada não afetou significativamente $(P>0,05)$ o consumo de MS e de MO. Segundo Orskov (1987) apesar da polpa de citros apresentar valores médios de FDA, ela tem um baixo teor de lignina (1\%), significando que a quase totalidade da fibra é digerida no rúmen do animal, não sendo a mesma um fator limitante ao consumo de matéria seca. Belibasakis et al. (1996) reportaram que a inclusão de polpa de citros não afetou o consumo de matéria seca em vacas de leite.

Houve uma tendência de efeito $(\mathrm{P}=0,14)$ do tipo de processamento do grão no aumento do consumo voluntário de MS e de MO. Essa tendência de aumento no consumo de matéria seca e matéria orgânica para os tratamentos MMG $(19,80$ e $18,28 \mathrm{~kg}$, respectivamente) quando comparado com o MF (18,93 e 17,50 kg, respectivamente) está de acordo com o encontrado por Aldrich et al. (1993), onde o maior consumo de matéria seca $(+1 \mathrm{~kg})$ ocorreu para os tratamentos onde a fonte de amido era de baixa degradabilidade ruminal (milho grão) quando comparado com uma fonte de alta degradabilidade ruminal (milho grão de alta umidade). Santos (1996) e Santos et al.(1997) também reportaram que o consumo de matéria seca para o tratamento sorgo laminado a seco foi $15 \%$ superior à média dos tratamentos que continham sorgo floculado. Yu et al.(1997) observaram que as vacas que se alimentaram de milho laminado à vapor consumiram $5 \%$ mais matéria seca que vacas alimentadas com milho floculado.

Poore et al. (1993), Chen et al. (1994), Oliveira et al. (1995) não encontraram efeito significativo do processamento do grão de sorgo (sorgo floculado $\mathrm{x}$ sorgo laminado a seco) sobre o consumo de matéria seca ou de matéria orgânica. Joy et al. (1997) não encontraram efeito significativo do processamento do milho (milho laminado a seco $\mathrm{x}$ milho floculado), sobre o consumo voluntário de matéria seca $\mathrm{e}$ matéria orgânica e da mesma forma, Lykos et al. (1997) também não encontraram efeito significativo entre três fontes de amido com diferentes taxas de degradação ruminal (baixa=milho quebrado; média=milho quebrado + milho grão de alta umidade; alta=milho grão de alta umidade)sobre o consumo voluntário de matéria seca e matéria 
orgânica. Wilkerson et al. (1997) trabalhando com milho moído ou laminado a seco e milho grão de alta umidade laminado ou moído, não encontraram efeito significativo na ingestão de matéria seca tanto para o tipo de grão quanto para o tipo de processamento.

Plascencia \& Zinn (1996) encontraram resultados contrários, onde o consumo voluntário de matéria seca e matéria orgânica para o tratamento milho laminado a seco foi $7 \%$ inferior que a média dos tratamentos que continham milho floculado a diferentes densidades. Chen et al (1995) já reportavam um efeito linear no consumo de matéria seca com o aumento na taxa ( $0 \%$ até $45 \%)$ de inclusão de milho floculado $360 \mathrm{~g} / \mathrm{l}$. Nussio (1997) da mesma forma, encontrou valores de consumo de matéria seca menores para os tratamentos com sorgo laminado a seco.

A inclusão parcial de polpa de citros peletizada não afetou significativamente $(\mathrm{P}>0,05)$ a digestibilidade aparente $\%$ da MS e da MO no trato total, assim como a quantidade digerida $(\mathrm{kg} / \mathrm{dia})$. Entretanto, houve uma tendência de aumento $(\mathrm{P}=0,13)$ na digestibilidade aparente $\%$ da $\mathrm{MS}(68,8 \%$ com polpa e $63,14 \%$ sem polpa $)$ e da MO (69,6\% com polpa e $64,0 \%$ sem polpa) no trato total com a inclusão de polpa de citros peletizada. Wing (1975) já havia demonstrado não existir nenhum efeito deletério da inclusão de polpa de citros sobre a digestibilidade da matéria seca. Schaibly \& Wing (1974) observaram que a digestibilidade da matéria seca aumentou até o nível de $67 \%$ de substituição de silagem de milho por polpa de citros em dietas para novilhos.

$\mathrm{O}$ tipo de processamento do grão aumentou significativamente $(\mathrm{P}<0,05)$ a digestibilidade aparente da MS e da MO no trato total, porém a quantidade digerida não foi afetada, provavelmente devido à tendência de menor consumo com o milho floculado. Esse aumento observado na digestibilidade da MS $(\mathrm{P}<0,03)$ e MO $(\mathrm{P}<0,03)$, com a floculação está de acordo com o encontrado por Aldrich et al. (1993), onde a maior digestibilidade da $\mathrm{MO}$ ocorreu para os tratamentos onde a fonte de amido era de alta degradabilidade ruminal quando comparado com uma fonte de baixa degradabilidade ruminal .

Chen et al. (1994), Chen et al. (1995b), Poore et al. (1993), Santos (1996), Santos et al.(1997), também reportaram que as digestibilidades da MS e/ou MO no trato total aumentaram nos tratamentos que continham sorgo ou milho floculado, 
comparado com os que continham grão laminado. Plascencia \& Zinn (1996) encontraram aumento significativo na digestibilidade da $\mathrm{MO}$ para os tratamentos com milho floculado $(390 \mathrm{~g} / \mathrm{l}=71,2 \%, 320 \mathrm{~g} / \mathrm{l}=72,6 \%$ e $260 \mathrm{~g} / \mathrm{l}=72,8 \%)$ quando comparado com milho laminado a seco ( $62,7 \%)$.

Joy et al. (1997) trabalhando com milho, não encontraram efeito significativo ( $\mathrm{P}>0,05)$ do processamento do grão ( laminado a seco $\mathrm{x}$ floculado), sobre a digestibilidade \% da MO no trato total. Entretanto, houve uma tendência $(\mathrm{P}<0,09)$ de valor mais elevado para o milho floculado a $310 \mathrm{~g} / \mathrm{l}$ em relação ao floculado a $390 \mathrm{~g} / \mathrm{l}$. Lykos et al. (1997) encontraram efeito linear sobre a digestibilidade da MO em relação as fontes de amido com diferentes taxas de degradação ruminal (baixa=milho quebrado $(68,7 \%) ;$ média $=$ milho quebrado + milho grão de alta umidade $(68,6 \%)$; alta=milho grão de alta umidade $(72,6 \%)$.

Wilkerson et al. (1997) observaram maior digestibilidade da MS e MO no trato total de vacas de leite recebendo dietas com milho de alta umidade, em relação ao milho seco. A moagem do milho $(6,4 \mathrm{~mm})$ aumentou a digestibilidade em relação à laminação. Knowlton et al. (1998) também trabalhando com milho moído ou laminado a seco e milho grão de alta umidade laminado ou moído, observaram maior efeito na digestibilidade da MS para os tratamentos com milho de alta umidade, sendo que o moído apresentou melhor digestibilidade que o laminado.

$\mathrm{Yu}$ et al. (1998) encontraram resultados um pouco diferentes. Trabalhando com vários tipos de procesamento de milho, estes autores, verificaram que a maior digestibilidade no trato total decorreu da utilização do milho laminado a vapor $(77,7 \%)$ e milho moído fino $(74,4 \%)$, seguidos de milho moído grosso $(72,7 \%)$, milho floculado a $360 \mathrm{~g} / \mathrm{l}(71,5 \%)$ e por último o milho floculado a $309 \mathrm{~g} / 1(69,1 \%)$. 


\subsubsection{Fibra em detergente neutro e Fibra em detergente ácido}

Os consumos médios e as digestibilidades aparentes da fibra em detergente neutro (FDN) e fibra em detergente ácido (FDA) dos quatro tratamentos, constam na Tabela 8.

Tabela 8. Efeito dos tratamentos no consumo e digestibilidade aparente da fibra em detergente neutro (FDN) e fibra em detergente ácido (FDA) no trato total.

\begin{tabular}{|c|c|c|c|c|c|c|c|c|}
\hline \multirow[b]{2}{*}{ Item $^{1}$} & \multicolumn{4}{|c|}{ Tratamentos $^{2}$} & \multirow[b]{2}{*}{$\mathbf{E P M}^{4}$} & \multicolumn{3}{|c|}{ Efeito $^{5}$} \\
\hline & MF & MMG & MFP & MMP & & $\mathbf{P R}$ & $\mathbf{P P}$ & $\begin{array}{c}\text { PRX } \\
\text { PP }\end{array}$ \\
\hline & & & & & & & $\mathrm{p}<$ & \\
\hline $\mathrm{CFDN} / \mathrm{Kg} / \mathrm{d}$ & $5,29^{b c}$ & $5,67^{\mathrm{ab}}$ & $5,78^{\mathrm{ab}}$ & $6,04^{\mathrm{a}}$ & 0,16 & 0,10 & 0,04 & 0,71 \\
\hline DFDNTT/Kg/d & $2,55^{\mathrm{a}}$ & $2,50^{\mathrm{a}}$ & $3,16^{\mathrm{a}}$ & $3,41^{\mathrm{a}}$ & 0,15 & 0,64 & 0,02 & 0,45 \\
\hline DFDNTT/ \% & $47,12^{b}$ & $45,33^{b}$ & $54,83^{\mathrm{a}}$ & $55,66^{\mathrm{a}}$ & 1,5 & 0,81 & 0,01 & 0,51 \\
\hline CFDA/ Kg /d & $3,02^{\mathrm{c}}$ & $3,27^{\mathrm{bc}}$ & $3,53^{\mathrm{ab}}$ & $3,70^{\mathrm{a}}$ & 0,10 & 0,08 & 0,05 & 0,69 \\
\hline DFDATT/Kg $/ \mathrm{d}$ & $1,31^{\mathrm{b}}$ & $1,36^{\mathrm{b}}$ & $1,90^{\mathrm{a}}$ & $1,97^{\mathrm{a}}$ & 0,07 & 0,47 & 0,05 & 0,82 \\
\hline DFDATT $/ \%$ & $41,70^{\mathrm{b}}$ & $41,04^{\mathrm{b}}$ & $53,55^{\mathrm{a}}$ & $52,35^{\mathrm{a}}$ & 1,8 & 0,67 & 0,05 & 0,90 \\
\hline
\end{tabular}

\footnotetext{
'Item : CFDN = consumo de FDN; CFDA = consumo de FDA; DFDNTT =digestibilidade aparente da FDN no trato digestivo total; DFDATT = digestibilidade aparente da FDA no trato digestivo total.

${ }^{2}$ Tratamentos: MF = milho floculado $360 \mathrm{~g} /$ litro; $\mathrm{MMG}=$ milho moído grosso $655 \mathrm{~g} /$ litro; MFP = milho floculado + polpa; MMP = milho moído grosso + polpa.

${ }^{3}$ Efeito $: \mathrm{PR}=$ Tipo de processamento do grão; $\mathrm{PP}=$ Polpa de citros peletizada; $\mathrm{PR} \times \mathrm{PP}=$ processamento $\times$ Polpa.

${ }^{4} \mathrm{EPM}=$ erro padrão da média.

abc Médias seguidas de letras distintas, na mesma linha, diferem entre si pelo teste de $\mathrm{t}$ (Student) a $5 \%$ de probabilidade .
} 
A inclusão parcial de polpa de citros peletizada aumentou $(\mathrm{P}<0,05)$ o consumo voluntário de FDN e FDA, provavelmente devido ao maior toor de fibra nessas dietas, uma vez que a polpa de citros possui um teor maior de FDN e FDA, quando comparada com o milho.

Ocorreu uma tendência $(\mathrm{P}=0,10$ e $\mathrm{P}=0,08)$ de maior consumo voluntário de FDN e FDA para os tratamentos com milho moído grosso (5,85 e 3,49 $\mathrm{kg} /$ dia) comparados com o milho floculado (5,54 e 3,28 kg/dia), devido ao maior consumo de matéria seca para o tratamento milho moído grosso.

A inclusão parcial de polpa de citros peletizada aumentou significativamente a digestibilidade aparente da FDN e FDA no trato total, tanto em $\mathrm{kg} / \mathrm{dia}$ quanto em percentual (\%). Observa-se que apesar do maior consumo de FDN e FDA, é provável que a alta digestibilidade da fibra da polpa citros como reportada por Schultz et al. (1993), Van Soest et al. (1991), e Van Soest (1994), aumentou significativamente a digestibilidade destes nutrientes no presente estudo.

Não houve efeito significativo $(\mathrm{P}>0,05)$ do tipo de processamento do grão sobre a digestibilidade da FDN e FDA. Estudos conduzidos por Aldrich et al. (1993), Chen et al. (1994) e Theurer et al. (1991) mostraram que a digestibilidade da fibra, no trato total, não foi afetada negativamente pelo aumento da disponibilidade ruminal de amido, enquanto outros trabalhos mostraram efeito negativo (Oliveira et al., 1995; Plascencia \& Zinn et al., 1996; Lykos et al., 1997; Joy et al., 1997 e Yu et al., 1998). 


\subsubsection{Amido e Proteína Bruta}

Os consumos médios e digestibilidades aparentes do amido e da proteína bruta dos quatro tratamentos, constam na Tabela 9.

Tabela 9. Efeito dos tratamentos, no consumo e digestibilidade aparente do amido (AM) e da proteina bruta $(\mathrm{PB})$ no trato total.

\begin{tabular}{|c|c|c|c|c|c|c|c|c|}
\hline \multirow[b]{2}{*}{ Item $^{1}$} & \multicolumn{4}{|c|}{ Tratamentos $^{2}$} & \multirow[b]{2}{*}{ EPM $^{4}$} & \multicolumn{3}{|c|}{ Efeito $^{3}$} \\
\hline & MF & MMG & MFP & MMP & & PR & $\mathbf{P P}$ & $\begin{array}{c}\text { PR X } \\
\text { PP }\end{array}$ \\
\hline & & & & & & & $\mathrm{p}<$ & \\
\hline $\mathrm{CAM} / \mathrm{Kg} / \mathrm{d}$ & $6,84^{a}$ & $7,07^{\mathrm{a}}$ & $4,72^{b}$ & $4,87^{\mathrm{b}}$ & 0,15 & 0,31 & 0,05 & 0,80 \\
\hline DAMTT/ Kg /d & $5,41^{a}$ & $4,46^{b}$ & $3,36^{\mathrm{c}}$ & $2,94^{\mathrm{c}}$ & 0,22 & 0,05 & 0,05 & 0,12 \\
\hline DAMTT/ \% & $93,44^{\mathrm{a}}$ & $71,70^{c}$ & $92,93^{a}$ & $80,12^{b}$ & 2,5 & 0,05 & 0,16 & 0,11 \\
\hline $\mathrm{CPB} / \mathrm{Kg} / \mathrm{d}$ & $3,45^{\mathrm{a}}$ & $3,53^{\mathrm{a}}$ & $3,37^{\mathrm{a}}$ & $3,50^{\mathrm{a}}$ & 0,10 & 0,34 & 0,60 & 0,80 \\
\hline DPBTT/ Kg /d & $2,57^{\mathrm{a}}$ & $2,37^{\mathrm{a}}$ & $2,54^{\mathrm{a}}$ & $2,50^{\mathrm{a}}$ & 0,13 & 0,40 & 0,75 & 0,60 \\
\hline DPBTT/ \% & $74,70^{\mathrm{ab}}$ & $67,05^{b}$ & $75,50^{\mathrm{a}}$ & $71,96^{\mathrm{ab}}$ & 2,25 & 0,05 & 0,26 & 0,40 \\
\hline
\end{tabular}

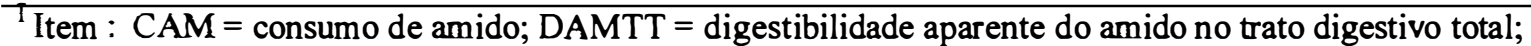
$\mathrm{CPB}=$ consumo de proteína bruta; $\mathrm{DPBTT}=$ digestibilidade aparente da matéria orgânica no trato digestivo total.

${ }^{2}$ Tratamentos: MF = milho floculado $360 \mathrm{~g} /$ litro; MMG = milho moído grosso $655 \mathrm{~g} / \mathrm{litro}$; MFP = milho floculado + polpa; MMP = milho moído + polpa.

${ }^{3}$ Efeito $: \mathrm{PR}=$ Tipo de processamento do grão; $\mathrm{PP}=$ Polpa de citros peletizada; $\mathrm{PR} \times \mathrm{PP}=$ processamento $\mathrm{x}$ Polpa.

${ }^{4} \mathrm{EPM}=$ erro padrão da média.

abc Médias seguidas de letras distintas, na mesma linha, diferem entre si pelo teste de $t$ (Student) a $5 \%$ de probabilidade . 
A inclusão parcial de polpa de citros peletizada em substituição ao milho, diminuiu significativamente $(\mathrm{P}<0,05)$ o consumo voluntário de amido $(6,95$ $\mathrm{kg} /$ dia para 4,80 kg/dia), devido ao teor de amido das dietas com polpa ser bem menor, uma vez que o teor de amido encontrado na polpa é mínimo, conforme mostrado na Tabela 5 .

Não foi observado efeito significativo do tipo de processamento do grão sobre o consumo de amido ( $P>0,05)$ estando de acordo com Aldrich et al.(1993), Poore et al (1993), Oliveira et al. (1995), Joy et al. (1997) e Lykos et al. (1997). O mesmo ocorreu com o consumo de proteína, estando de acordo com Wilkerson et al. (1998).

Houve uma tendência $(\mathrm{P}=0,12$ e $\mathrm{P}=0,11)$ de interação do tipo de processamento do grão com a polpa de citros peletizada (fonte de energia) sobre a digestibilidade do amido expressa em $\mathrm{kg} / \mathrm{dia}$ ou percentual. A tendência de interação entre o tipo de processamento do grão com a polpa de citros peletizada, através do efeito de diluição, aumentou a digestibilidade percentual do amido para o tratamento milho moído de $71,70 \%$ para $80,12 \%$. Com a substituição parcial do milho moído grosso (baixa degradabilidade ruminal) por polpa de citros peletizada, os animais ingeriram menores quantidades de amido e segundo Orskov (1986), Theurer (1986) e Huntington (1997), existe uma limitação enzimática para digestão de amido no intestino delgado. Neste caso, a quantidade que chegou foi menor, o que, provavelmente melhorou a digestibilidade. Já com o milho floculado não houve efeito da adição da polpa de citros peletizada provavelmente devido a já elevada digestibilidade ruminal e intestinal do amido neste material.

$\mathrm{O}$ aumento da digestibilidade do amido, tanto em $\mathrm{kg} / \mathrm{dia}$ quanto em percentual, com a floculação, também foi observado por Aldrich et al., 1993; Oliveira et al., 1995; Plascencia \& Zinn, 1997 e Poore et al., 1993. Chen et al., 1994; Chen et al., 1994; Santos, 1996; Santos et al., 1997; Yu et al., 1997 e Yu et al., 1998.

Observou-se efeito significativo $(\mathrm{P}<0,05)$ do tipo de processamento do grão no aumento da digestibilidade da proteína em percentual, que foi maior para o tratamento milho floculado $(74,705 \%)$, quando comparado com o milho 
moído (67,05\%). Estes dados diferem de Yu et al. (1998), que trabalhando com vários tipos de processamento de milho observaram maiores digestibilidades da proteína bruta para os materiais menos processados (laminado a vapor $(75,6 \%)$, moído grosso $(71 \%)$, floculado a $360 \mathrm{~g} / \mathrm{l}(68 \%)$ e floculado a $309 \mathrm{~g} / \mathrm{l}(65 \%))$.

\subsection{Parâmetros ruminais}

Tabela 10. Efeito do processamento do milho e sua substituição parcial por polpa de citros peletizada sobre os parâmetros ruminais.

\begin{tabular}{|c|c|c|c|c|c|c|c|c|}
\hline \multirow[b]{2}{*}{ Parâmetros } & \multicolumn{4}{|c|}{ Tratamentos $^{1}$} & \multirow[b]{2}{*}{$\mathrm{EPM}^{3}$} & \multicolumn{3}{|c|}{ Efeito $^{2}$} \\
\hline & $\mathbf{M F}$ & MMG & MFP & MMP & & PR & PP & $\begin{array}{c}\text { PR X } \\
\text { PP }\end{array}$ \\
\hline & & & & & & \multicolumn{3}{|c|}{$\mathrm{P}<$} \\
\hline $\mathrm{PH}$ & $6,02^{\mathrm{a}}$ & $6,12^{a}$ & $6,04^{a}$ & $6,12^{a}$ & 1,00 & 0,21 & 0,90 & 0,87 \\
\hline Amônia - N, mg/dl & $21,2^{b}$ & $30,5^{a}$ & $20,7^{b}$ & $27,0^{\mathrm{a}}$ & 1,20 & 0,008 & 0,35 & 0,48 \\
\hline \multicolumn{9}{|l|}{$\underline{\mathrm{AGV}}$} \\
\hline Total, mM & $117,8^{\mathrm{a}}$ & $122,5^{\mathrm{a}}$ & $119,7^{\mathrm{a}}$ & $124,5^{\mathrm{a}}$ & 1,70 & 0,22 & 0,59 & 0,99 \\
\hline Acetato, $\%$ & $58,1^{\mathrm{c}}$ & $62,5^{a}$ & $61,0^{b}$ & $63,5^{a}$ & 0,56 & 0,001 & 0,01 & 0,18 \\
\hline Propionato, \% & $22,9^{a}$ & $20,1^{b}$ & $21,9^{\mathrm{a}}$ & $19,7^{b}$ & 0,50 & 0,01 & 0,38 & 0,72 \\
\hline Butirato, $\%$ & $13,8^{\mathrm{a}}$ & $12,2^{\mathrm{a}}$ & $12,3^{\mathrm{a}}$ & $12,6^{\mathrm{a}}$ & 0,54 & 0,40 & 0,48 & 0,24 \\
\hline Acetato/Propionato & $2,56^{\mathrm{a}}$ & $3,11^{b}$ & $2,79^{a}$ & $3,26^{\mathrm{b}}$ & 0,22 & 0,04 & 0,15 & 0,75 \\
\hline \multicolumn{9}{|c|}{$\begin{array}{l}\text { Tratamentos: } \mathrm{MF}=\text { milho floculado } 360 \mathrm{~g} / \text { litro; } \mathrm{MM}=\text { milho moído grosso } 655 \mathrm{~g} / \text { litro; } \mathrm{MF}+\mathrm{P}=\text { milho } \\
\text { floculado }+ \text { polpa; } \mathrm{MM}+\mathrm{P}=\text { milho moído }+ \text { polpa. } \\
{ }^{2} \text { Efeito }: \mathrm{PR}=\text { Tipo de processamento do grão; } \mathrm{PP}=\text { Polpa de citros peletizada; } \mathrm{PR} \times \mathrm{PP}=\text { processamento } \\
\times \text { Polpa. } \\
{ }^{3} \mathrm{EPM}=\text { Erro padrão da média. } \\
\text { abc Médias seguidas de letras distintas, na mesma linha, diferem entre si pelo teste de } \mathrm{t} \text { (Student) a } 5 \% \text { de } \\
\text { probabilidade. }\end{array}$} \\
\hline
\end{tabular}




\subsection{1 $\mathrm{pH}$ no líquido ruminal}

Os dados médios de pH encontram-se na Tabela 10. Não houve efeito significativo $(\mathrm{P}>0,05)$ dos tratamentos sobre os valores médios de $\mathrm{pH}$ ruminal. Entretanto, quando as médias são comparadas dentro dos tempos de amostragem, observa-se claramente na Figura 2, comportamentos diferentes entre os tratamentos. Houve uma tendência $(\mathrm{P}=0,085)$ no tempo 2 ( 2 horas), do tratamento milho floculado + polpa apresentar valores menores de $\mathrm{pH}$, quando comparado com o tratamento milho moído. $\mathrm{O}$ tratamento milho floculado também apresentou valor muito baixo de $\mathrm{pH}$ $(5,89)$. No tempo 4 , os valores de $\mathrm{pH}$ entre os tratamentos não diferem estatisticamente $(\mathrm{P}>0,05)$, entretanto, observa-se claramente que o tratamento milho floculado+polpa ainda continua com valores de $\mathrm{pH}$ abaixo de 5,8. No tempo 6, ocorreu um aumento no valor de $\mathrm{pH}$ para o tratamento milho floculado+polpa e apesar de não ter havido diferença significatica entre os tratamentos, o milho floculado+polpa apresentou maior valor numérico de $\mathrm{pH}(5,97)$. Nos tempos 8 e 10 observou-se uma curva ascendente para os valores de $\mathrm{pH}$ nos quatro tratamentos, os quais também não diferiram entre si estatisticamente $(\mathrm{P}>0,05)$, embora os valores de $\mathrm{pH}$ para o tratamento milho floculado tenham sido numericamente inferiores aos demais.

A análise da Figura 2 mostra alguns aspectos interessantes de fermentação ruminal das dietas que devem ser notados, ainda que as médias dos tratamentos não tenham sido diferentes. $O$ tratamento milho floculado+polpa apresentou valores de $\mathrm{pH}$ ruminal muito baixos após as refeições até o tempo 4 , o que reflete o grande percentual médio de carboidratos solúveis (30\% segundo Carvalho,1998) na polpa de citros peletizada, bem como a alta taxa de degradação ruminal da pectina ( $30 \mathrm{a}$ 50\%/hora, segundo Sniffen, 1988; Van Soest, 1994; Chesson \& Monro, 1982). Embora os valores médios para os tratamentos com polpa não tenham se diferenciado significativamente dos demais ( $\mathrm{P}>0,05)$, o que está de acordo com Rocha Filho (1998) e Carvalho (1998), existem dados de literatura conflitantes. Pinzon \& Wing (1976) observaram diminuição dos valores de $\mathrm{pH}$ ruminal a medida que se incluiu a polpa de 
citros, o que também foi observado por Schaibly \& Wing (1974). Em outros trabalhos a polpa de citros provocou até aumento de $\mathrm{pH}$ ruminal segundo Wing (1975).

Portanto, neste trabalho, o aumento na digestibilidade da FDN e FDA no trato digestivo total (Tabela 8) após a inclusão de polpa de citros na dieta, provavelmente se deve à uma maior participação de fibra altamente digestível proveniente deste alimento e a uma menor disponibilidade de carboidratos não estruturais para serem fermentados no intestino grosso, permitindo uma maior digestibilidade da fibra neste compartimento, tendo um efeito compensatório sobre uma possível menor digestão de fibra no rúmen.

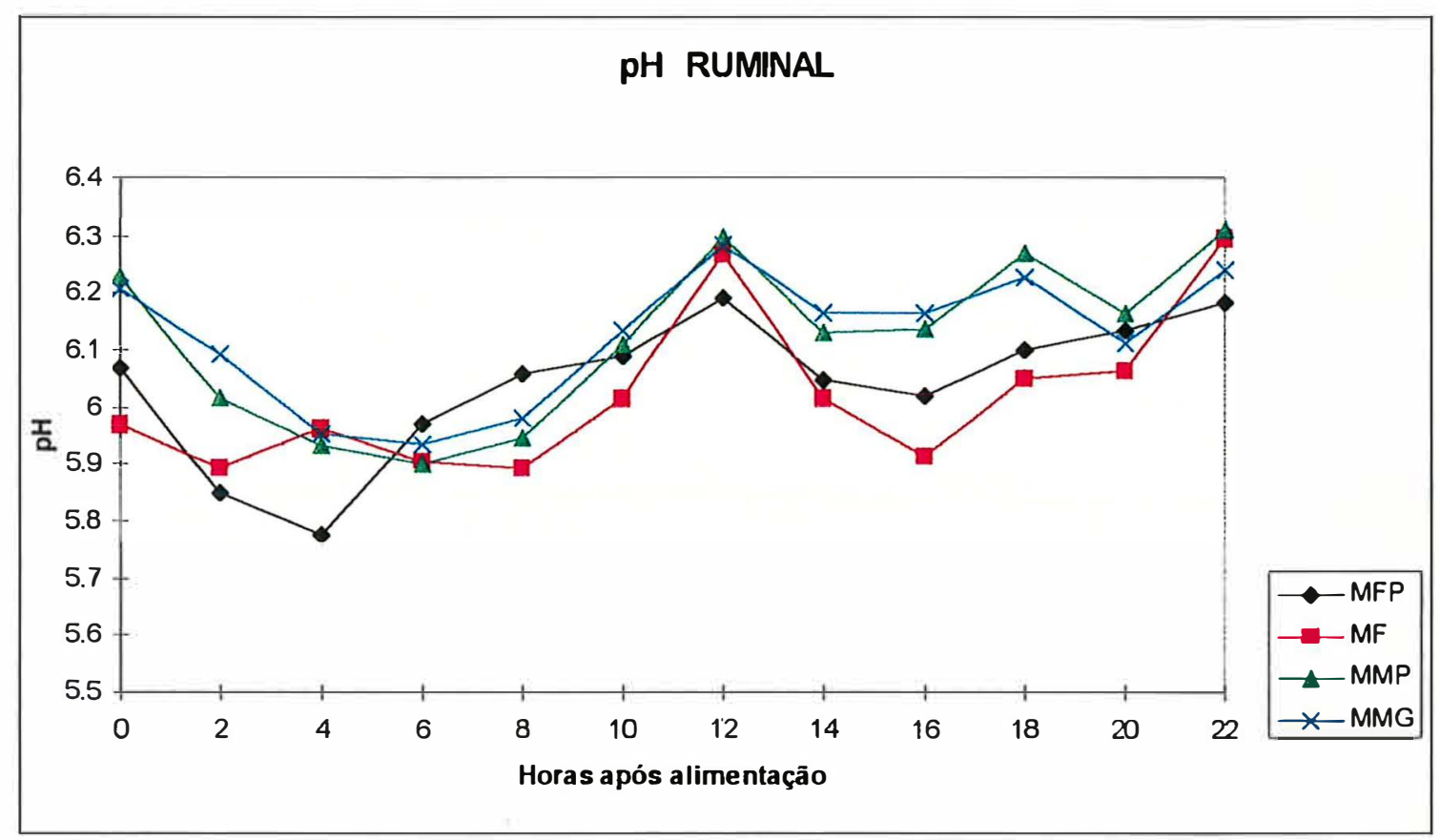

Figura 2. Efeito das dietas experimentais sobre o $\mathrm{pH}$ ruminal nos diferentes tempos de amostragem. 
Valores muito baixos de $\mathrm{pH}$ ruminal e oscilações ao longo do tempo, principalmente após as refeições, foram observados no tratamento milho floculado, o que reflete a maior degradabilidade numinal do amido processado. $\mathrm{O}$ efeito da diminuição do $\mathrm{pH}$ ruminal devido a utilização de uma fonte de amido mais degradável no rúmen, tem sido reportado por vários autores como Lykos et al. (1997) e Nussio (1997). Porém, neste trabalho a inexistência de diferença significativa entre os valores médios de $\mathrm{pH}$ ruminal para os tratamentos milho floculado e milho moído, concordam com Joy et al. (1997) e Plascencia \& Zinn (1995).

Possivelmente, a tendência de queda brusca no $\mathrm{pH}$ após as 12 horas nos tratamentos milho floculado e milho floculado + polpa pode estar relacionada com a segunda refeição diária com grande ingestão. Como o consumo não foi avaliado ao longo do dia, esta correlação não pôde ser feita. Porém, normalmente, os animais apresentavam padrão de consumo muito definido, com grande ingestão de alimento logo após o fornecimento.

\subsubsection{Nitrogênio Amoniacal $\left(\mathrm{N}-\mathrm{NH}_{3}\right)$ no líquido ruminal}

Os dados médios de nitrogênio amoniacal encontram-se na tabela 10. Quando comparados os valores médios de nitrogênio amoniacal, observa-se efeito significativo $(\mathrm{P}<0,05)$ do tipo de processamento do milho. Os valores médios de nitrogênio amoniacal foram $40 \%$ menores para o tratamento milho floculado (MF) quando comparado com o milho moído grosso (MMG). A maior disponibilidade de amido degradável no rúmen nas dietas contendo milho floculado permitiu uma utilização do nitrogênio amoniacal mais eficiente, sugerindo uma maior síntese de proteína 
microbiana com estas dietas, como também relatada por Plascencia \& Zinn (1997); Poore et el. (1993) e Santos (1998).

Todos os valores médios de nitrogênio amoniacal obtidos neste trabalho podem ser considerados altos quando comparados com os dados obtidos por diversos autores ( Aldrich et al., 1993; Joy et al., 1997; LyKos et al., 1997), porém próximos aos valores de Nussio (1997) e de Santos (1998).

Quando as médias são comparadas dentro dos tempos de amostragem, observa-se claramente na Figura 3, comportamentos diferentes entre os tratamentos. Todos os tratamentos aumentaram seus valores médios de nitrogênio amoniacal após a primeira alimentação, entretanto, houve aumento significativo $(\mathrm{P}<0,01)$ e uma tendência de aumento $(\mathrm{P}=0,09)$ nos valores de nitrogênio amoniacal, no tempo 2 ( 2 horas), para os tratamentos milho moído grosso (MMG) e milho moído+polpa (MMP), respectivamente, quando comparados com o milho floculado+polpa. No tempo 4, observa-se uma queda numérica significativa dos níveis de nitrogênio amoniacal $(\mathrm{P}<0,05)$ para os tratamentos MFP e MF quando comparados com o tratamento MMG, refletindo a maior taxa de degradação ruminal do milho floculado em relação ao milho menos processado (Oliveira et al., 1995; Plascencia \& Zinn, 1997; Teixeira et al., 1997), resultando em maior disponibilidade de energia, tornando assim, mais eficiente o uso do nitrogênio amoniacal para a síntese de proteína microbiana. Nos tempos 6 até 12 horas o tratamento MMG, apresentou uma curva descendente em relação aos valores de nitrogênio amoniacal, entretanto os valores ainda são significativamente superiores aos do tratamento MF e MFP.

A adição de polpa de citros peletizada não afetou o nível de amônia ruminal, mesmo nas dietas contendo milho moído grosso, onde a redução foi apenas numérica mas não significativa. Em contradição ao observado no presente trabalho, Pinzon \& Wing (1976), Valk et al. (1990) e McCullough (1995) relataram redução nos níveis de amônia ruminal com a inclusão de polpa de citros na dieta. 


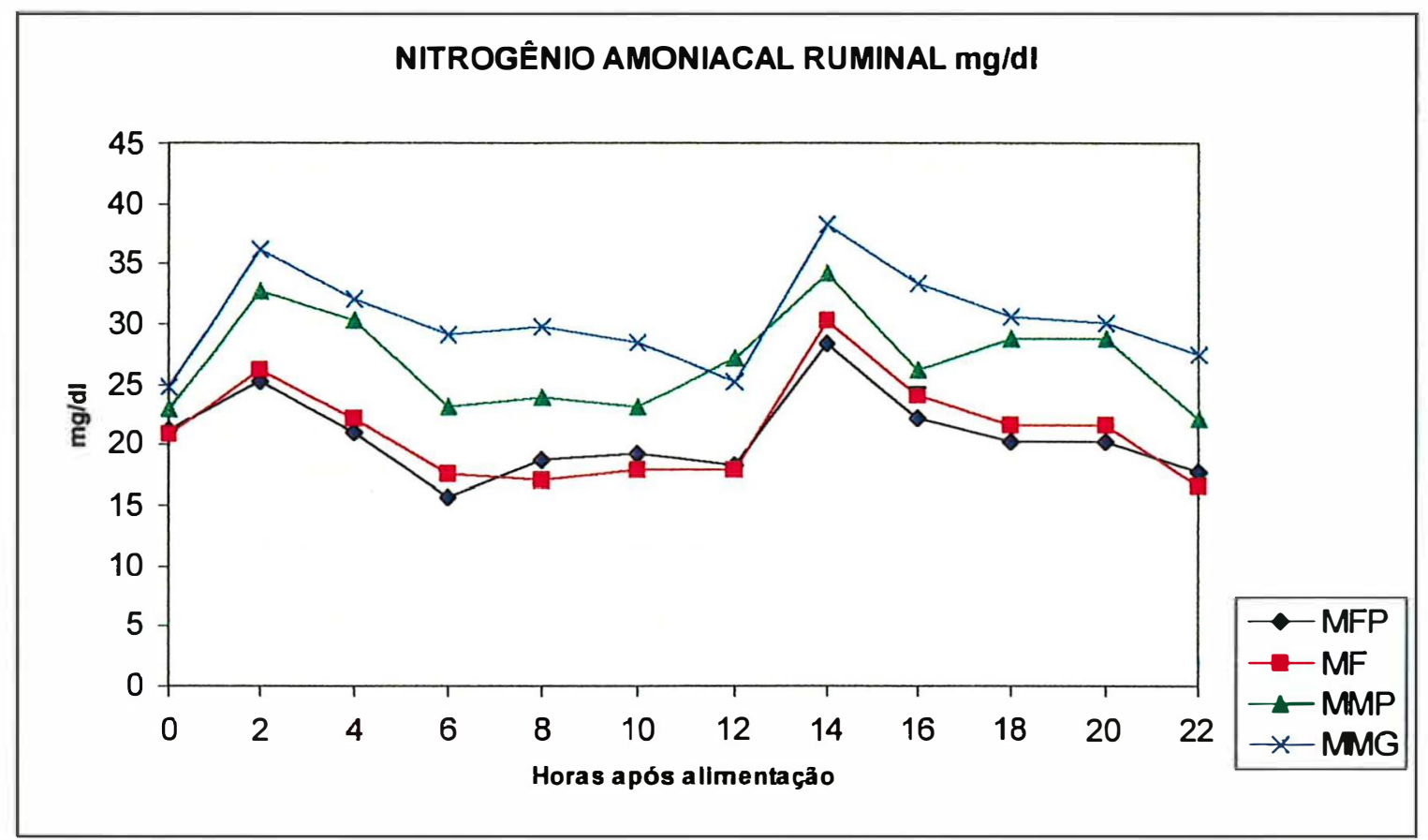

Figura 3. Efeito dos tratamentos sobre o nitrogênio amoniacal ruminal nos diferentes tempos de amostragem.

Possivelmente, o aumento significativo nos valores de nitrogênio amoniacal das 12 -14 horas para todos os tratamentos está relacionado com o fato de ter havido a segunda refeição diária com grande ingestão. Como o consumo não foi avaliado ao longo do dia, esta correlação não pôde ser feita. Porém, normalmente, os animais apresentavam padrão de consumo muito definido, com grande ingestão de alimento logo após os dois fornecimentos de alimento diário. Após este horário as curvas seguem o mesmo comportamento discutido anteriormente. 


\subsection{AGVs no líquido ruminal}

\subsubsection{Concentração total de ácidos graxos voláteis}

Os dados médios de concentração molar de ácidos graxos voláteis totais (AGVT) encontram-se na Tabela 10. Não houve efeito significativo $(P>0,05)$ dos tratamentos sobre os valores médios da concentração molar de AGVT. Vários dados de literatura não encontraram resultados significativos de aumento na concentração molar de AGVT, quando o grão floculado ou grão de milho úmido, substituiu o grão moído ou laminado (Aldrich et al., 1993; Joy et al., 1997; Lykos et al., 1997). Entretanto, quando as médias foram comparadas dentro dos tempos (Figura 4) de amostragem, observou-se diferenças significativas entre os tratamentos. Houve um efeito significativo $(\mathrm{P}<0,05)$ no tempo 2 (2 horas), do tratamento milho moído+polpa (MMP), o qual apresentou maiores valores de AGVT quando comparado com milho floculado (MF) e milho floculado+polpa (MFP). Não houve diferença no tempo 4, enquanto no tempo 6 o MMP e MMG apresentaram valores maiores $(\mathrm{P}<0,05)$ quando comparados com MF. Nos tempos 8 e 10 observou-se queda na concentração de AGVT para todos os tratamentos, o que provavelmente esteve relacionado com um tempo significativo após a primeira refeição onde grande parte dos componentes de alta degradabilidade das dietas foram fermentados. No tempo 16 o tratamento milho moído apresentou valores médios superiores $(\mathrm{P}<0,05)$ em relação aos demais tratamentos. 


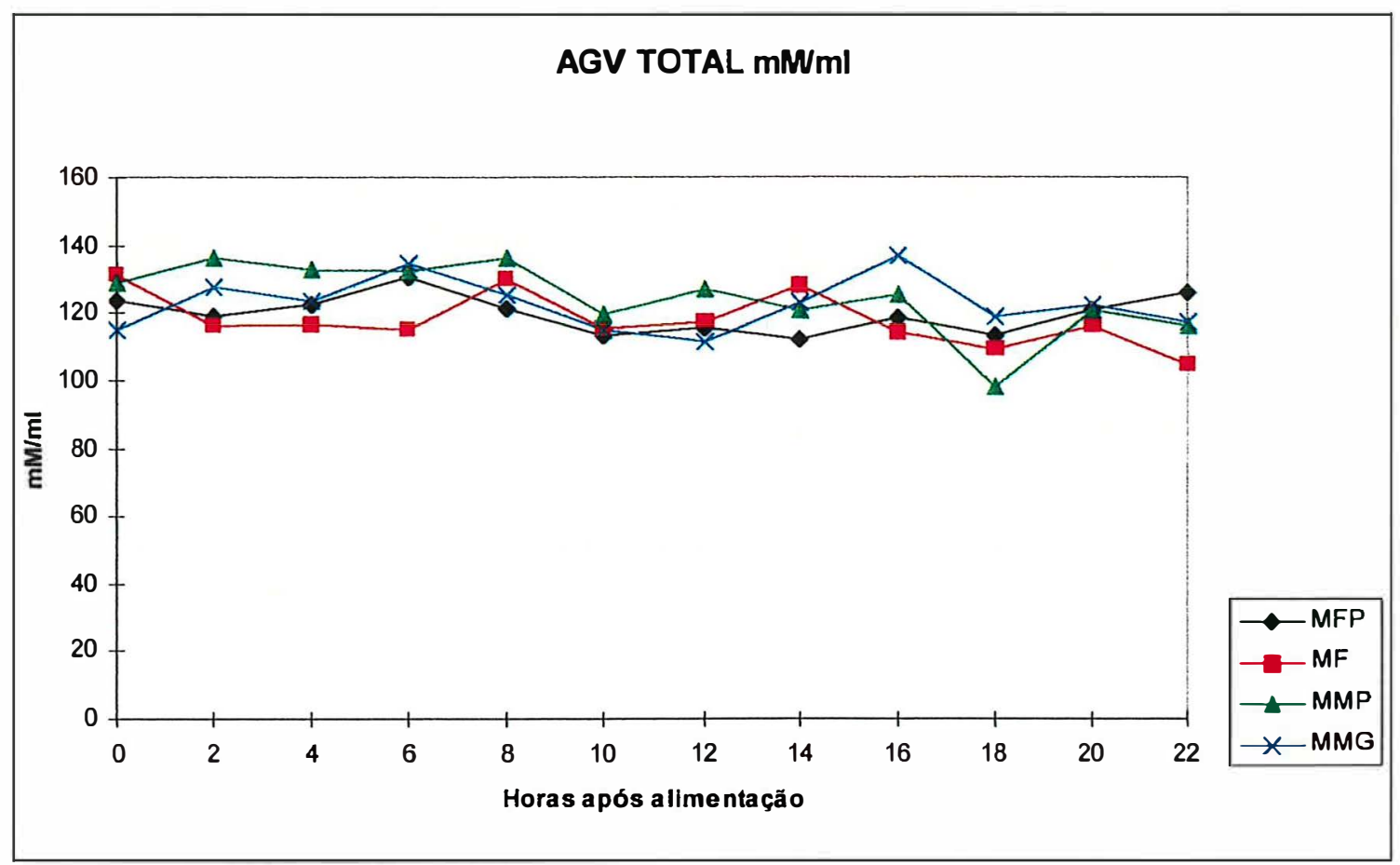

Figura 4. Efeito dos tratamentos sobre a concentração molar total de ácidos graxos voláteis.

\subsubsection{Acetato}

Os dados Tabela 10 mostram que houve efeito significativo $(\mathrm{P}<0,05)$ da inclusão de polpa e do tipo de processamento do grão na proporção molar de acetato ruminal. $\mathrm{O}$ tratamento MMP apresentou valores superiores quando comparado com MF e MFP, sendo que o tratamento MFP apresentou maior proporção molar de acetato ruminal que o MF. Estes resultados encontrados estão de acordo com a 
literatura, onde segundo Van Soest (1987) a substituição de produtos com alto teor de amido, por alimentos com alto teor de pectina favorece a fermentação acética. Vários outros autores atestaram o aumento do percentual molar de acetato quando se incluiu a polpa de citros na dieta (Hentges et al.,1966; Loggins et al., 1964; Shaibly \& Wing,1974; Wing, 1982; Rocha Filho 1998). O percentual médio de acetato ruminal foi significativamente maior para o MMG quando comparado com o MF e está de acordo com Plascencia \& Zinn (1996) e Joy et al.(1997), os quais compararam milho laminado e milho floculado.

Quando as médias foram comparadas dentro dos tempos de amostragem (Figura 5), observou-se diferenças entre os tratamentos. O tratamento MMP apresentou percentuais médios de acetato maiores que os tratamentos MFP e MF $(\mathrm{P}<0,05)$, em todos os tempos. Da mesma forma o tratamento MMG apresentou percentuais médios de acetato maiores que o tratamento MF em todos os tempos. 


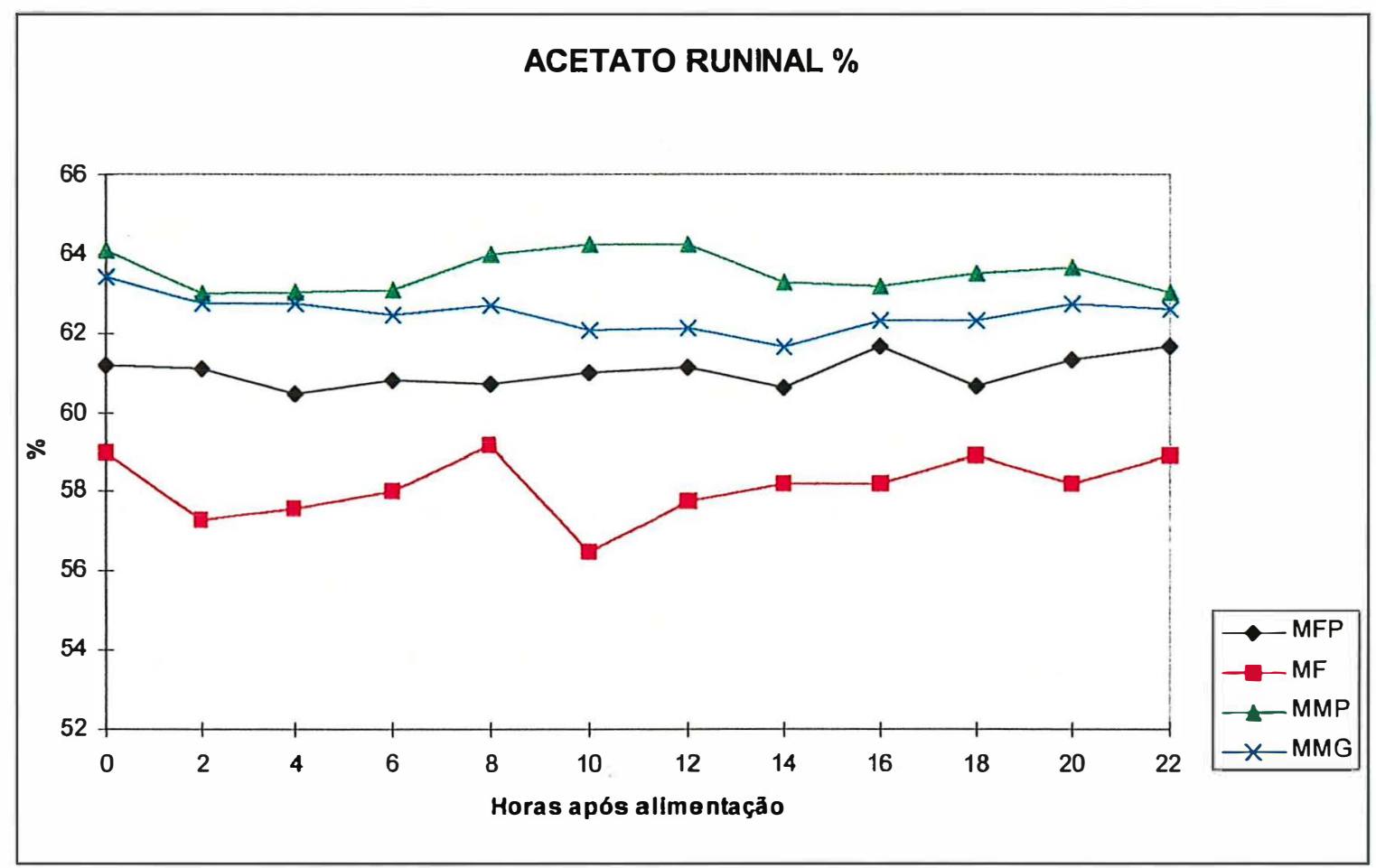

Figura 5. Efeito dos tratamentos sobre a proporção molar de acetato ruminal

\subsubsection{Propionato}

Os dados médios da proporção molar de propionato em relação à concentração molar de ácidos graxos voláteis totais mostram que houve efeito significativo $(\mathrm{P}<0,05)$ do tipo de processamento do grão (Tabela 10). O tratamento $\mathrm{MF}$ apresentou maior proporção molar de propionato quando comparado com MMG e MMP. Estes resultados encontrados estão de acordo com a literatura, onde segundo Van Soest (1994) produtos com alto teor de amido geram uma maior produção de propionato. 
Vários outros autores também relataram um aumento do percentual molar de propionato quando se incluiu uma fonte de amido de alta degradação ruminal na dieta (Joy et al., 1997; Plascencia \& Zinn, 1996). Observou-se que os tratamentos contendo milho floculado (MF e MFP) apresentaram maiores proporções molares de propionato ruminal que os tratamentos contendo milho moído grosso (MMG e MMP) de forma consistente ao longo dos tempos de amostragem (Figura 6).

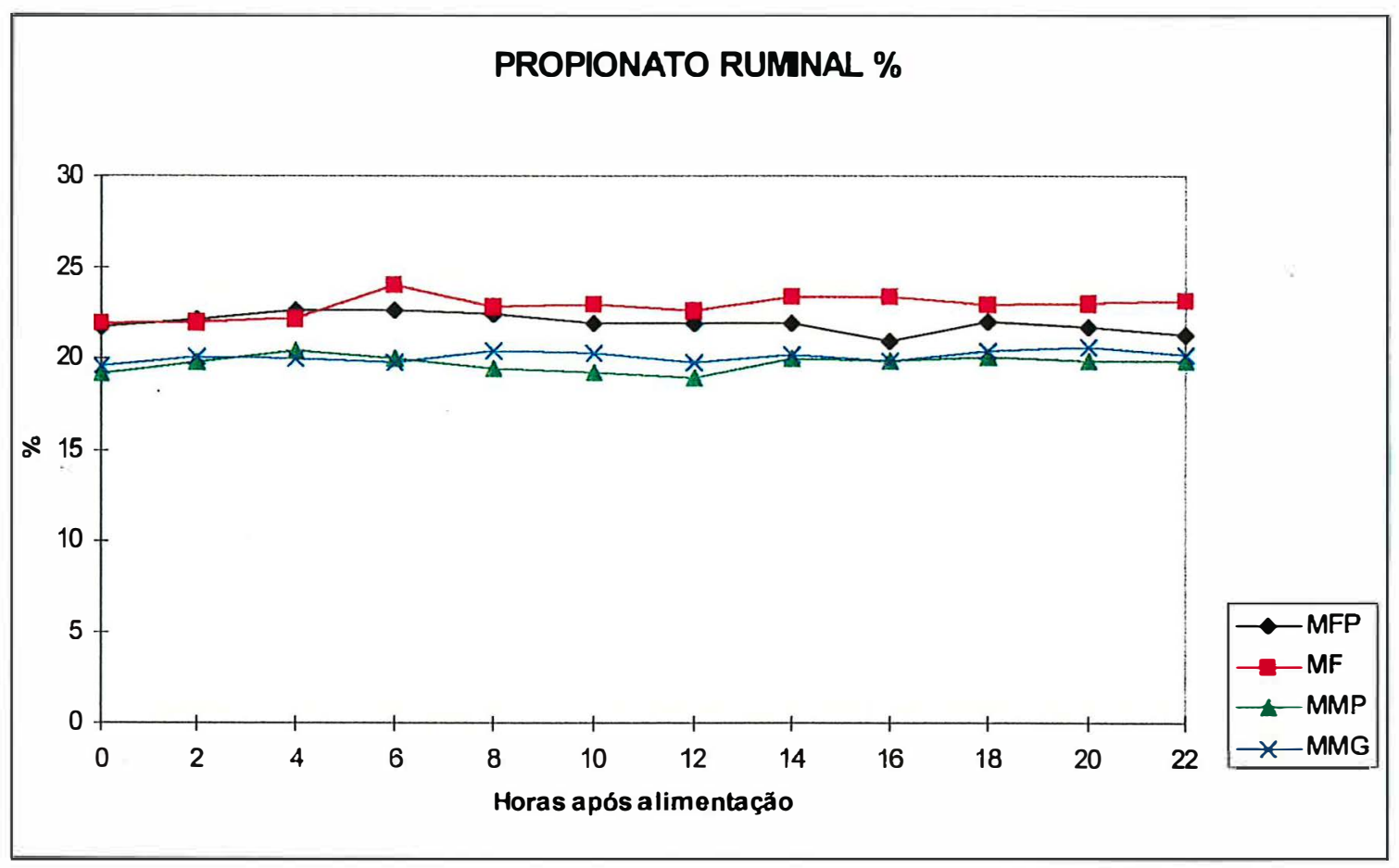

Figura 6. Efeito das dietas experimentais sobre o percentual molar de propionato ruminal. 


\subsubsection{Butirato}

Os dados médios da proporção molar de butirato em relação a concentração molar de ácidos graxos voláteis totais mostram que não houve efeito significativo $(\mathrm{P}>0,05)$ dos tratamentos (Tabela 10$)$. Em vários trabalhos de pesquisa não foram observados efeitos significativos na proporção molar de butirato, quando o grão floculado substituiu o grão laminado (Joy et al., 1997; Plascencia \& Zinn, 1996). Entretanto, quando as médias foram comparadas dentro dos tempos de amostragem (Figura 7), observou-se um aumento significativo $(\mathrm{P}<0,05)$ da concentração molar de butirato nos tempos $2,4,10$ e 12 horas no tratamento milho floculado (MF), comparado com os demais tratamentos.

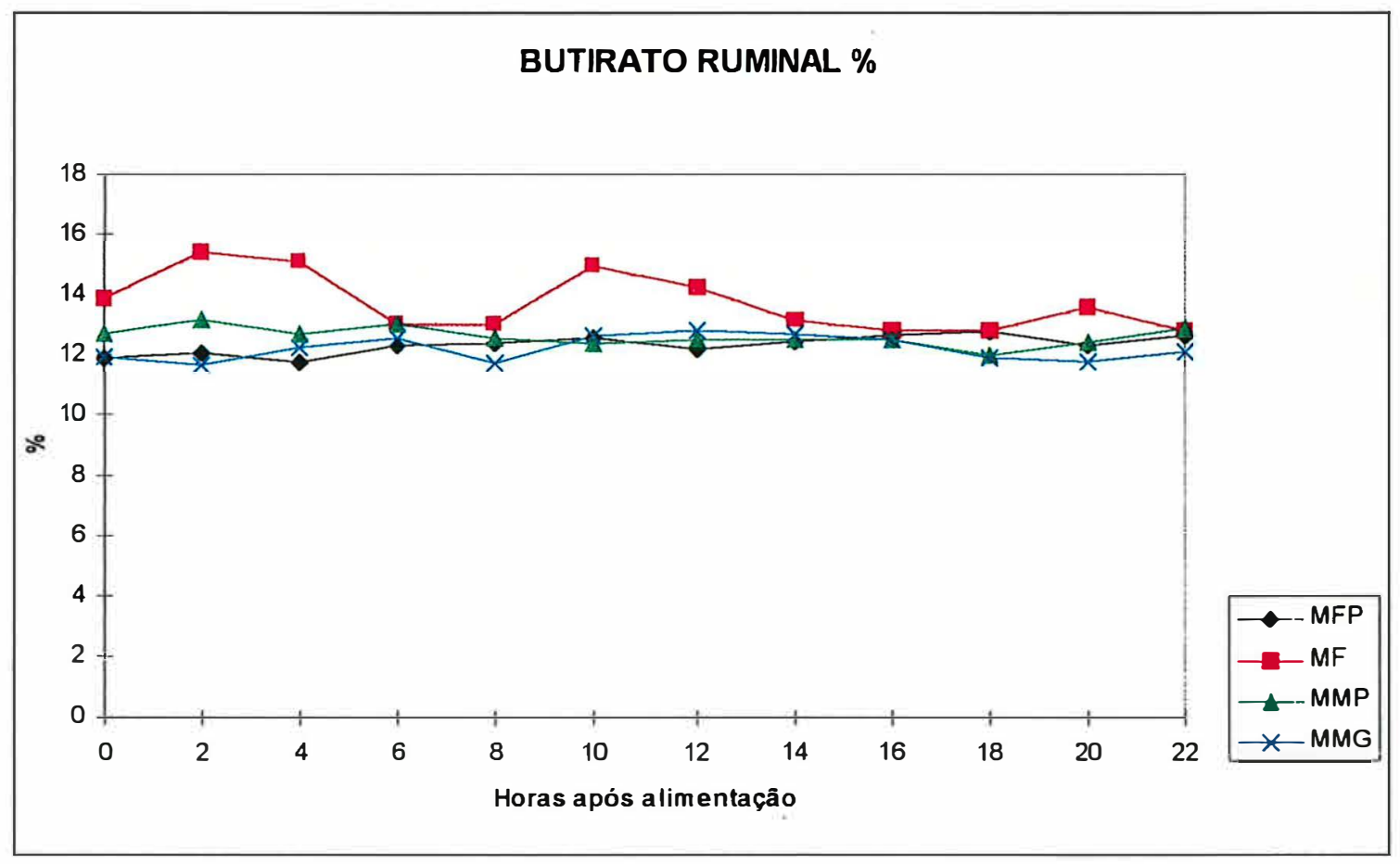

Figura 7. Efeito das dietas experimentais sobre o percentual molar de butirato ruminal. 


\subsubsection{Acetato/Propionato}

Houve efeito significativo $(\mathrm{P}<0,05)$ do tipo de processamento do milho sobre a proporção de acetato/propionato, com redução desta proporção, com o uso de milho floculado (Tabela 10). Efeito similar foi observado por Joy et al. (1997) e Lykos et al. (1997). Quando as médias foram comparadas dentro dos tempos de amostragem (Figura 8), observou-se uma diminuição significativa $(\mathrm{P}<0,05)$, na relação acetato/propionato nos tempos 0 até 22 horas para o tratamento MF quando comparado com MMG e MMP, o que reflete os menores percentuais de acetato e maiores de propionato já citados anteriormente para o tratamento MF.

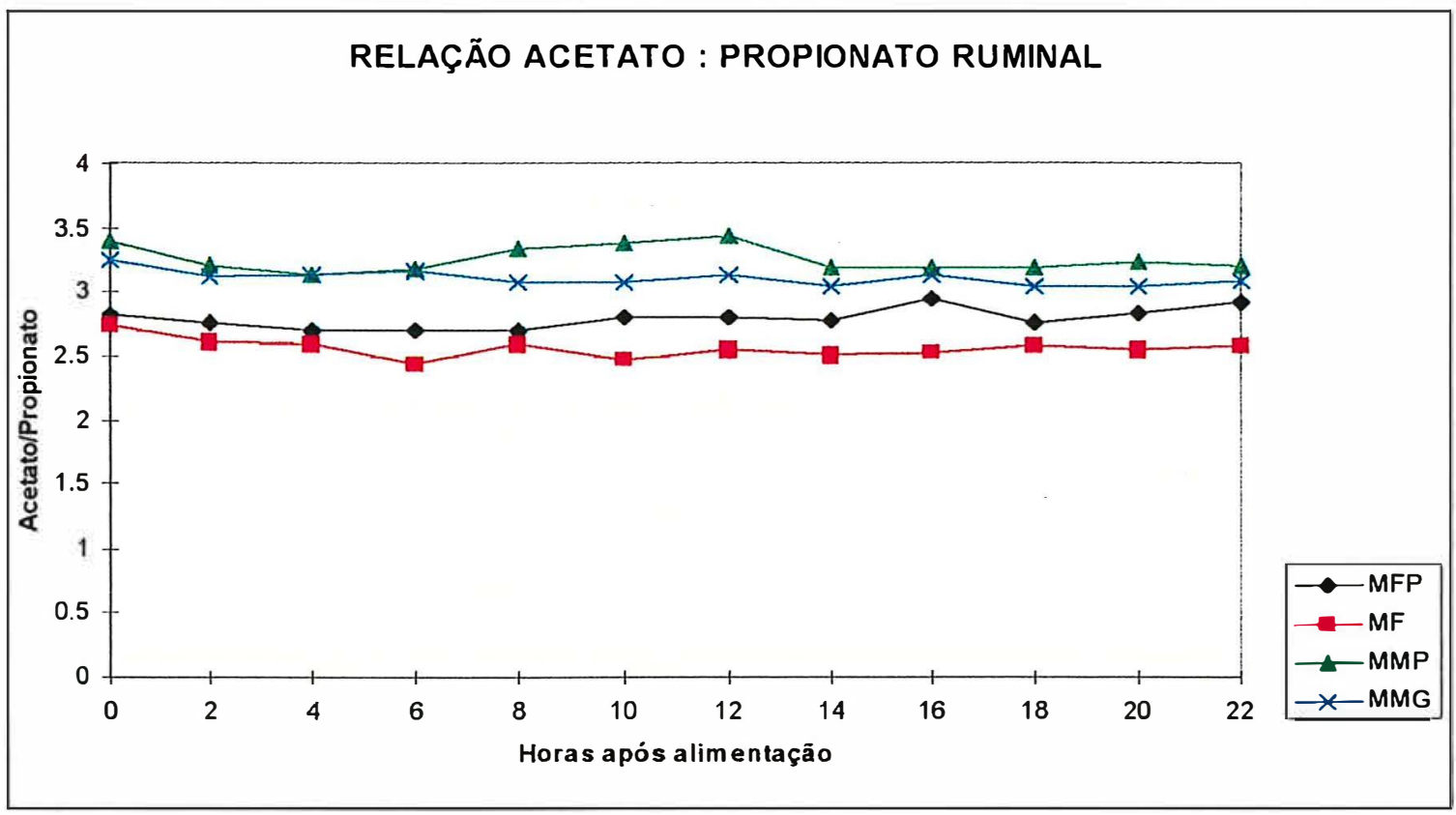

Figura 8. Efeito das dietas experimentais sobre a proporção molar de acetato : propionato ruminal. 


\subsection{Parâmetros sanguíneos}

\subsubsection{Glucose plasmática}

Tabela 11. Efeito dos tratamentos sobre os parâmetros sanguíneos.

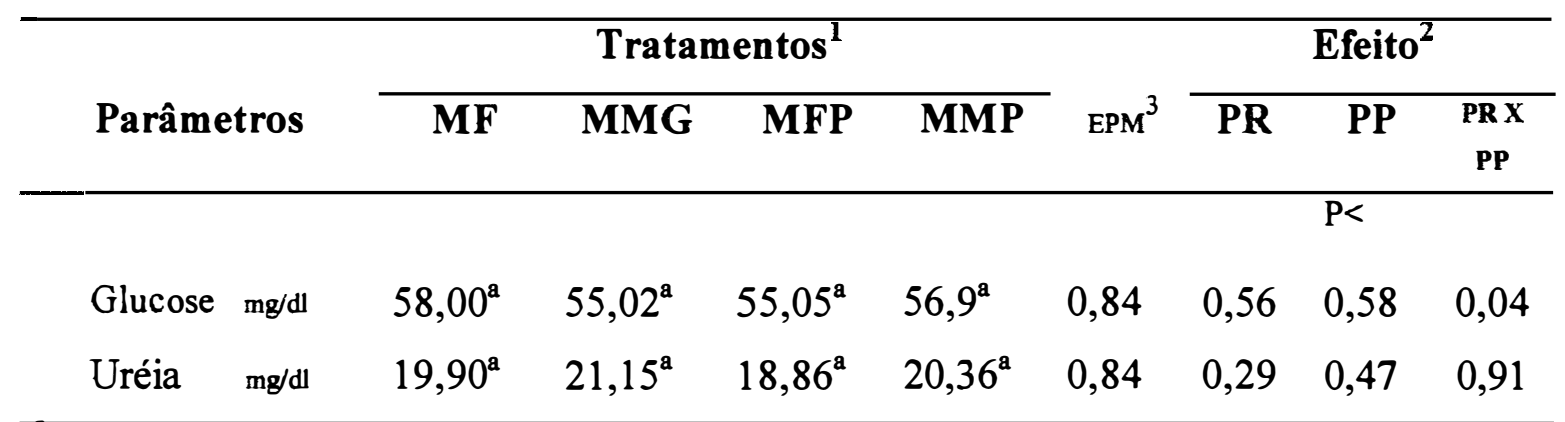

TTratamentos: MF = milho floculado 360g /litro; MMG = milho moído grosso 655 g/litro; MFP = milho floculado + polpa; MMP = milho moído + polpa

${ }^{2}$ Efeito : $\mathrm{PR}=$ Tipo de processamento do grão; $\mathrm{PP}=$ Polpa de citros peletizada; $\mathrm{PR} \times \mathrm{PP}=$ processamento $\mathrm{x}$ Polpa.

${ }^{3} \mathrm{EPM}=$ Erro padrão da média.

${ }^{a}$ Médias seguidas de letras distintas, na mesma linha, diferem entre si pelo teste de $t$ (Student) a $5 \%$ de probabilidade .

Os dados médios de glucose plasmática (Tabela 11) mostram que não houve diferença significativa $(\mathrm{P}>0,05)$ entre os tratamentos, o que está de acordo com a literatura, onde Lykos et al. (1997) trabalhando com diferentes niveis de amido degradável no rúmen, também não observaram diferenças entre os tratamentos. Entretanto, houve uma tendência $(\mathrm{P}=0,06)$ de aumento das concentrações de glucose plasmáticas para o tratamento MF quando comparado com MMG e MFP, o que pode estar relacionado com a maior proporção molar de ácido propiônico que segundo Huntington (1997) é o principal substrato para síntese de glucose no figado em vacas de leite. 
Quando as médias foram comparadas dentro dos tempos de amostragem, observou-se que $o$ tratamento $\mathrm{MF}$ apresentou maiores $(\mathrm{P}<0,05)$ concentrações de glucose plasmática que o MMG nos tempos 3 e 6 , havendo uma tendência no tempo 9 (Figura 9).

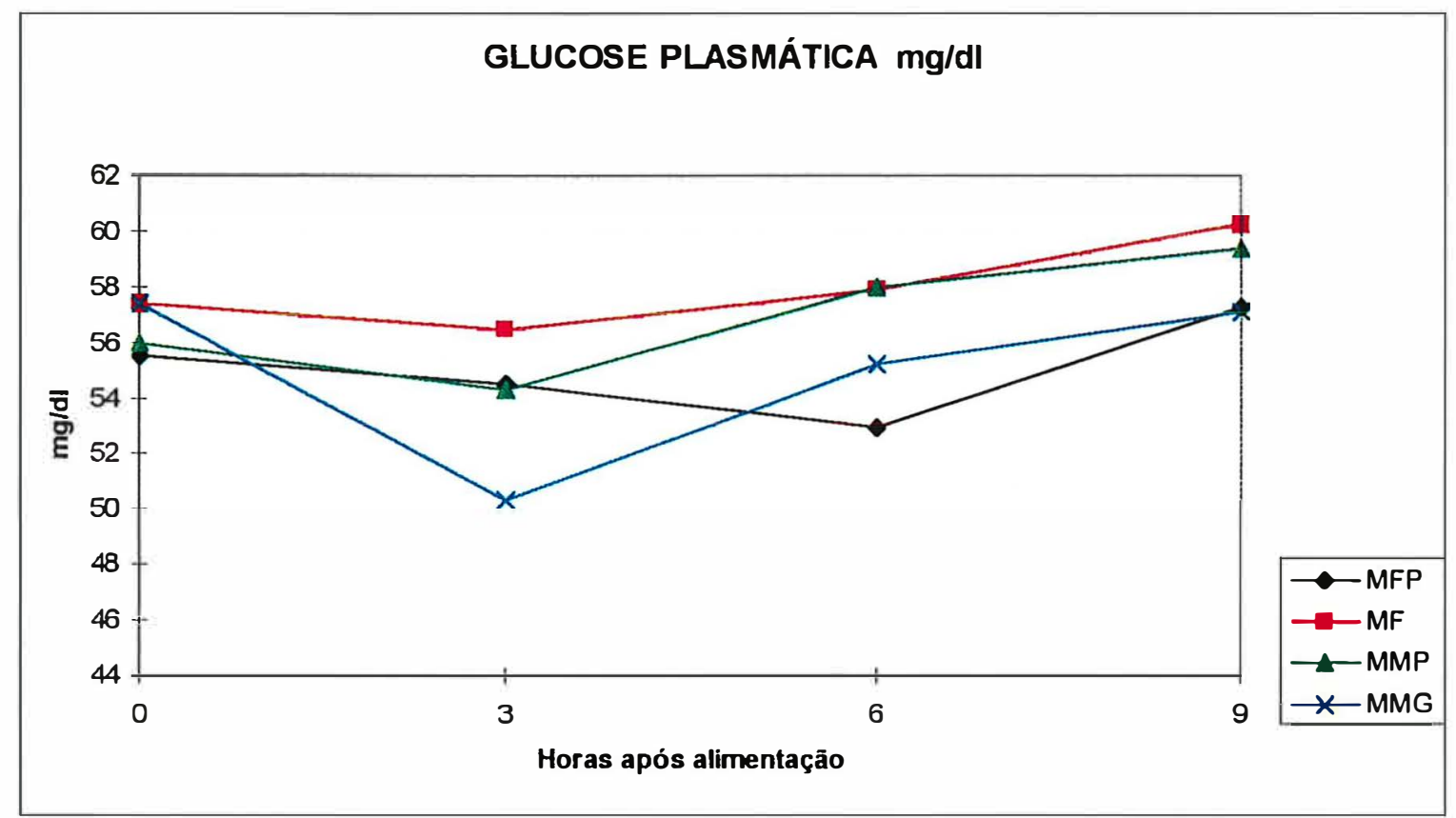

Figura 9. Efeito das dietas experimentais sobre as concentrações plasmáticas de glucose $(\mathrm{mg} / \mathrm{dl})$.

Houve interação significativa $(\mathrm{P}<0,05)$ entre $\mathrm{o}$ tipo de processamento do grão e inclusão de polpa de citros peletizada. No caso do milho floculado a inclusão de polpa de citros diminuiu o valor médio de glucose plasmática. 


\subsubsection{Uréia plasmática}

Os dados na tabela 11 , mostram que não houve diferença $(\mathrm{P}>0,05)$ na concentração de uréia plasmática entre os tratamentos. Aldrich et al.(1993) também não encontraram diferenças entre os valores médios de uréia plasmática, com a inclusão de fonte de amido prontamente disponível no rúmen em relação a uma fonte de baixa disponibilidade ruminal. Vale ressaltar que os níveis mais elevados de amônia ruminal nos tratamentos contendo amido menos degradável no rúmen (MMG e MMP) não se refletiram em níveis mais elevados de uréia plasmática. Broderick \& Clayton (1997) concluíram que a concentração de uréia no sangue e no leite são altamente correlacionadas entre si, mas que a correlação entre amônia ruminal e uréia no sangue ou leite é baixa.

A comparação entre os tratamentos dentro dos tempos de amostragem mostrou que apenas no tempo 6 houve diferença significativa entre os tratamentos, com valores mais elevados de uréia plasmática para o MMG em relação aos demais tratamentos (Figura 10).

Estes resultados coincidem com os valores mais altos de nitrogênio amoniacal no rúmen para o tratamento $\mathrm{MMG}$ neste período de tempo e mostrados anteriormente. Segundo Hoover \& Stokes (1991) a falta de energia disponível no rúmen, pode acarretar em maior absorção de nitrogênio pelo epitélio ruminal. Van Soest (1994) também comenta que a baixa taxa de liberação de energia no rúmen limita o uso de nitrogênio não protéico por assincronia e desta forma, há aumento da absorção de amônia pelo epitélio ruminal, elevando o nível de uréia no sangue e aumentando a excreção pela urina. 


\section{URÉIA PLASMÁTICA mg/dI}

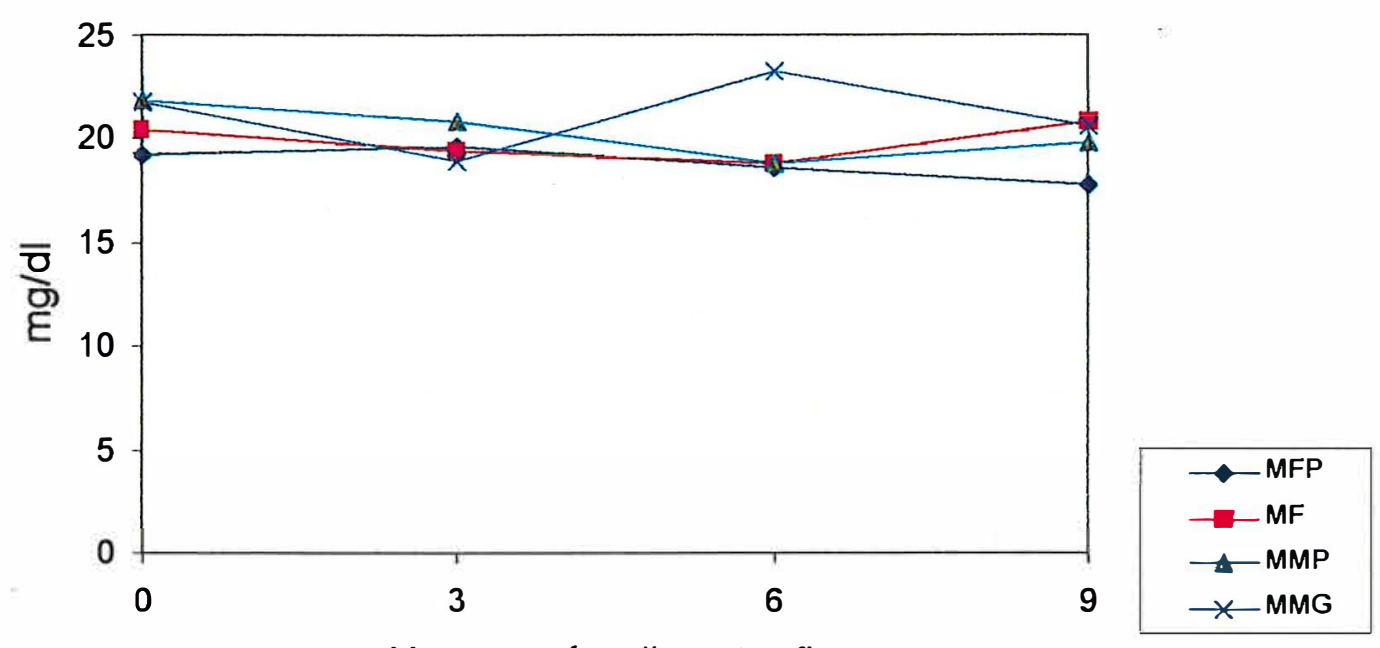

Horas após alimentação

Figura 10. Efeito das dietas experimentais sobre a concentração de uréia plasmática. 


\subsection{Produção, composição do leite e eficiên cia alimentar}

As produções médias de leite, composição do leite e eficiência alimentar, dos quatro tratamentos, constam na Tabela 12.

Tabela 12. Dados de produção e composição do leite.

\begin{tabular}{|c|c|c|c|c|c|c|c|c|}
\hline \multirow[b]{2}{*}{ Item $^{1}$} & \multicolumn{4}{|c|}{ Tratamentos ${ }^{2}$} & \multirow[b]{2}{*}{ EPM 4} & \multicolumn{3}{|c|}{ Efeito $^{3}$} \\
\hline & MF & MMG & MFP & MMP & & PR & $\overline{\mathbf{P P}}$ & $\begin{array}{c}\text { PRX } \\
\text { PP }\end{array}$ \\
\hline & & & & & & & $\mathrm{p}<$ & \\
\hline $\mathrm{CMS} / \mathrm{Kg} / \mathrm{d}$ & $19,00^{\mathrm{a}}$ & $19,94^{\mathrm{a}}$ & $18,86^{\mathrm{a}}$ & $19,67^{\mathrm{a}}$ & 0,25 & 0,14 & 0,69 & 0,91 \\
\hline $\mathrm{PL} / \mathrm{kg}$ dia & $22,56^{\mathrm{a}}$ & $21,28^{\mathrm{a}}$ & $22,41^{a}$ & $21,98^{\mathrm{a}}$ & 0,27 & 0,20 & 0,66 & 0,50 \\
\hline $\operatorname{PLCG}(3,5 \%) / \mathrm{kg}$ dia & $20,72^{\mathrm{a}}$ & $20,11^{\mathrm{a}}$ & $22,28^{\mathrm{a}}$ & $22,20^{\mathrm{a}}$ & 0,32 & 0,70 & 0,07 & 0,77 \\
\hline E. A & $1,11^{\mathrm{a}}$ & $1,02^{b}$ & $1,20^{\mathrm{a}}$ & $1,14^{\mathrm{a}}$ & 0,07 & 0,17 & 0,06 & 0,66 \\
\hline Proteína Leite / \% & $3,23^{\mathrm{a}}$ & $3,17^{\mathrm{a}}$ & $3,18^{\mathrm{a}}$ & $3,07^{b}$ & 0,07 & 0,09 & 0,13 & 0,50 \\
\hline Gordura Leite / \% & $2,98^{\mathrm{b}}$ & $3,19^{\mathrm{a}}$ & $3,47^{\mathrm{a}}$ & $3,59^{\mathrm{a}}$ & 0,14 & 0,36 & 0,03 & 0,79 \\
\hline Proteína Leite $/ \mathrm{Kg}$ & $0,73^{\mathrm{a}}$ & $0,67^{\mathrm{a}}$ & $0,71^{\mathrm{a}}$ & $0,68^{\mathrm{a}}$ & 0,06 & 0,11 & 0,85 & 0,71 \\
\hline Gordura Leite / Kg & $0,67^{\mathrm{a}}$ & $0,67^{\mathrm{a}}$ & $0,77^{\mathrm{a}}$ & $0,78^{\mathrm{a}}$ & 0,07 & 0,91 & 0,04 & 0,91 \\
\hline
\end{tabular}

${ }^{1}$ Item : CMS = consumo de matéria seca; $\mathrm{PL}=$ produção de leite. $\mathrm{PLCG}=$ produção de leite corrigida para gordura. EA = eficiência alimentar (PLCG /CMS).

${ }^{2}$ Tratamentos: $\mathrm{MF}=$ milho floculado $360 \mathrm{~g}$ /litro; $\mathrm{MMG}=$ milho moído grosso $655 \mathrm{~g} /$ litro; MFP = milho floculado + polpa; MMP = milho moído + polpa

${ }^{3}$ Efeito $: \mathrm{PR}=$ Tipo de processamento do grão; $\mathrm{PP}=$ Polpa de citros peletizada; $\mathrm{PR} \times \mathrm{PP}=$ processamento $\mathrm{x}$ Polpa.

${ }^{4} \mathrm{EPM}=$ Erro padrão da média.

${ }^{\mathrm{ab}}$ Médias seguidas de letras distintas, na mesma linha, diferem entre si pelo teste de $\mathrm{t}$ (Student) a $5 \%$ de probabilidade. 
A produção de leite não foi afetada pelos tratamentos de forma significativa, diferindo da grande maioria dos trabalhos publicados (Chen et al., 1995; Santos et al., 1997; Theurer et al., 1995; Wilkerson et al., 1997), os quais têm mostrado de forma consistente que o aumento da degradabilidade ruminal do amido através da floculação ou uso de grão de alta umidade resulta em maior produção de leite para vacas alimentadas com milho ou sorgo.

Houve efeito significativo $(\mathrm{P}<0,05)$ da inclusão de polpa de citros peletizada no aumento do teor e $\mathrm{kg}$ de gordura do leite e uma tendência $(\mathrm{P}=0,07)$ para maior produção de leite corrigido para 3,5\% de gordura. Esse aumento no percentual de gordura do leite e na produção de leite corrigido para gordura, também foi observado por Belibasakis et al. (1996); Drude et al. (1971); Lucci et al. (1975); Van Horn et al. (1975) também observaram aumento no percentual de gordura do leite com a inclusão de polpa de citros peletizada na dieta. O efeito da inclusão de polpa de citros peletizada no aumento da digestibilidade das frações fibrosas da dieta e na proporção molar de acetato, é a provável causa do maior teor de gordura no leite, maior produção de $\mathrm{kg}$ de gordura do leite e consequente maior produção de leite corrigido.

Houve uma tendência de aumento no percentual $(\mathrm{P}=0,09)$ e $\mathrm{kg}$ $(\mathrm{P}=0,11)$ de proteína do leite em relação ao tipo de processamento do grão. Pode ter havido um aumento na passagem de proteína microbiana para o duodeno aumentando a quantidade total de proteína no intestino, assim como, melhorando o perfil de aminoácidos essenciais da proteína metabolizável, uma vez que a proteína microbiana tem um exelente perfil de aminoácidos essenciais, principalmente em termos de lisina e metionina resultando em aumento no percentual de proteína do leite. Os resultados encontrados reforçam vários trabalhos metabólicos e/ou de produção, onde a floculação do milho e/ou sorgo ou milho grão úmido, quando comparados com grão moído ou laminado a seco, aumentaram o teor e a produção de proteína do leite (Aldrich et al., 1993; Chen et al., 1995; Plascencia \& Zinn, 1997; Lykos et al., 1997; Santos, 1996; Santos et al., 1997; Wilkerson et al., 1998; Yu et al., 1997). Observou-se também uma tendência $(\mathrm{P}=0,13)$ de diminuição no percentual de proteína do leite quando da inclusão de poipa de citros. 
A inclusão de polpa de citros tendeu $(\mathrm{P}<0,06)$ melhorar a eficiência alimentar (PLCG /CMS) dos animais, o que pode ser explicado pela maior PLCG . 


\section{CONCLUSÕES}

O aumento da degradabilidade ruminal dos carboidratos não estruturais da dieta, através da substituição do milho moído grosso por milho floculado ou por polpa de citros, teve efeito benéfico no desempenho de vacas de leite.

A floculação do milho aumentou as digestibilidades da M.S, M.O, amido e proteína da dieta, aumentando assim a disponibilidade de energia e proteína para o metabolismo do animal. A floculação também reduziu a concentração de amônia no fluído ruminal, indicando um melhor aproveitamento da proteína degradável no rúmen e uma provável maior síntese de proteína microbiana.

A maior produção de propionato pode ter resultado em uma maior síntese hepática de glucose e daí a provável explicação para a maior concentração de glucose plasmática para o grão floculado em relação ao moído grosso.

A produção de leite foi numericamente maior e o consumo de M.S menor para o milho floculado, resultando em melhor eficiência alimentar quando comparado com o moído grosso. A produção de proteína do leite também foi maior para o milho floculado comparado ao moído grosso.

A inclusão de polpa de citros peletizada aumentou as digestibilidades da M.S, M.O, FDN, FDA das dietas contendo ambos os tipos de milho e aumentou a digestibilidade do amido nas dietas contendo milho moído grosso.

A proporção molar de acetato foi aumentada, resultando em maior teor de gordura no leite e maior produção de leite corrigido para 3,5\% de gordura, assim como, maior eficiência alimentar em comparação às dietas contendo apenas milho. 
A combinação de milho floculado e polpa de citros peletizada, em dietas contendo silagem de milho como volumoso, parece ser o mais indicado pois foi o tratamento que resultou em melhor digestibilidade de nutrientes, com menor valor de amônia ruminal (indicando efeito positivo na síntese microbiana), alta produção de leite e leite corrigido, maior eficiência alimentar e melhor composição de leite em termos de gordura e proteína. 


\section{REFERÊNCIAS BIBLIOGRÁFICAS}

AOAC. Association of Official Analytical Chemists. Official Methods of Analysis. 12. ed., Washinton, D. C., 1990.

ALDRICH, J. M.; MULLER, L. D.; VARGA, G. A.; GRIEL, L. C. Nonstructural carbohydrate and protein effects on rumen fermentation, nutrient flow, and performance of dairy cows. Journal of Dairy Science, v.76, p.1091, 1993.

AMARAL, D. M.; VEENHUIZEN, J. J.; DRACKLEY, J. K. et al. Metabolism of propionate, glucose, and carbon dioxide as affected by exogenous glucose in dairy cows at energy equilibrium. Journal of Dairy Science, v. 73. P.1244, 1990.

ARGENZIO, R. A. Digestion and Absortion of Carbohydrated, fat, and protein. In: Melvin J. Swenson. (Ed.). Duke's Physiology of Domestic Animals. Ithaca, New York, 1984. cap. 18, p. 301-310.

ARMENTANO, L. E. Ruminant hepatic metabolism of volatile fatty acids, lactate and pyruvate. Journal of Nutrition, v.122, p.838-842, 1992.

BAUACHEMIN, K. A.; McALLISTER T. A.; DONG, Y.; FARR B.I.; CHENG, K-J.; Effects of mastication on digestion of whole cereal grains by cattle. Journal of Animal Science, v.72, p.236, 1994. 
BELIBASAKIS, N. G.; TSIRGOGIANNI, D. Effects of dried citrus pulp on milk yield, milk composition and blood components of dairy cows. Animal Feed Science and Technology, v.60, n.1-2, p. 87-92, 1996. /Resumo em CAB Abstracts on CDROM, 1996-1998.

BEN-GHELDALIA, D.; YOSEF, E.; MIRON, J.; EST, Y. The effects of starch and pectin rich diets on quantitative aspects of digestion on sheeps. Animal Feed Science and Technology, v.24, p. 289-298, 1989.

BERGMAN, E. N. Energy contributions of volatile fatty acids from the gastrointestinal tract in various species. Physiological Reviews, v.70, n.2, 1990.

CARVALHO, M. P. Citros. In: SIMPÓSIO SOBRE NUTRIÇÃO DE BOVINOS, 6; Piracicaba, 1995. Anais. Piracicaba:FEALQ, 1995. p.171-214.

CARVALHO, M. P. Substituição do milho por subprodutos energéticos em dietas de bovinos à base de bagaço de cana tratado à pressão e vapor : digestibilidade e parâmetros ruminais. Piracicaba, 1998. 120p. Dissertação (M.S.) Escola Superior de Agricultura Luiz de Queiroz, Universidade de São Paulo.

CHANEY, A. L. \& MARBACH, E. P. Modified reagents for determination of urea and amonia. Clinical Chemistry, v.8, p. 130-37, 1962.

CHESSON, A. \& MONRO, J. Legume pectic substances and their degradation in the ovine rumen. J. Sci. Food Agric, 33:852, 1982.

CHEN, K. H.; HUBER, J. T.; THEURER, C. B.; SWINGLE, R. S.; SIMAS, J. M. et al. Effect of steam flaking of corn and sorghum grains on performance of lactating cows. Journal of Dairy Science, v.77, p.1038, 1994. 
CHEN, K. H.; HUBER, J. T.; THEURER, C. B.; SIMAS, J. M. et al. Effect of substituiting steam-flaked sorghum for concentrate, on lactation and digestion in dairy cows. Journal of Dairy Science, v.78, p.362, 1995.

CLARK, J. H.; KLUSMEYER, T. H.; CAMERON, M. R. Symposium: nitrogen metabolism and amino acid nutrition in dairy cattle. Journal of Dairy Science, v.75, p.2304-23, 1992.

CROOM, W. J.; BULL, L. S. Review: Regulation of pancreatic exocrine secretion in ruminants. Journal of Nutrition, v.122, p. 191-202, 1992.

DEAVILLE, E. R; MOSS, A. R.; GIVENS, D. I. The nutritive value and chemical composition of energy-rich by products for ruminants. Animal Feed Science and Technology. v.49, p.261276, 1994.

DRUDE, R. E.; ESCANO, J. R.; RUSOFF, L. L. Value of complete feeds containing combinations of corn silage, alfafa pellets, citrus pulp, and cottonseed hulls for lactating cows. Journal of Dairy Science, v.54, p. 773, 1971.

FAHEY, G. C. \& BERGER, L. L. Carbohydrate nutrition of ruminants. In: $\mathrm{CHURCH}$, D. C. The Animal Digestive Physiology and Nutrition . New Jersey : Prentice Hall , 1988. p.269.

FARIA, V. P.; TOSI, H.; GODOY, C. R. M.; Polpa de laranja fresca e seca como aditivos para a ensilagem do capim elefante napier. $\mathbf{O}$ solo, Piracicaba, v.64, n.1, p. $41-47,1972$.

FEGEROS, K.; ZERVAS, G.; STAMOULI, S. et al. Nutritive value of dried citrus pulp and its effect on milk yield and milk composition of lactating ewes. Journal of Dairy Science, v. 78, p.1116-1121, 1995. 
GIARDINI, W.; Polpa de citros: o que é. Revista Batavo - encarte técnico, n.23, p 04, 1993.

GOHL, B. I. Citrus by-products for animal feed. World Animal Review. v.6, p.24-27, 1973.

GRAY, G.M. Starch digestion and absorption in nonnuminants. Journal of Nutrition. v.122, p.172, 1992.

HALL, M. B. Pectin: The structural non-structural carbohydrate . In: Cornell Nutrition Conference. Cornell University, Ithaca, N. Y, 1995, p. 29-36.

HALE, W. H. Influence of processing on the utilization of grains (starch) by ruminants. Journal of Animal Science, v.37, p.1075, 1973.

HARMON, D. L. Review: Impact of nutrition on pancreatic exocrine and endocrine secretion in ruminants. Journal of Animal Science, v.70, p.1290-1301, 1992.

HARMON, D. L. Dietary influences on carbohydrases and small intestinal starch hydrolysis capacity in ruminants. Journal of Nutrition, v.122, p.203-210, 1992.

HETGES, J. F. Jr.; MORE, J. E.; PALMER, A. Z.; CARPENTER, J. W. Replacement value of died citrus meal for corn meal in beef cattle diets. Gainsville: University of Flórida ( Bulletin 708). Agricultural Experiment. Station, 1966.

HILL, T. M.; SCHMIDT, S. P; RUSSEL, R. W et al. Comparison of urea treatment with established methods of sorghum grain preservation and processing on site and extent of starch digestion by cattle. Journal of Dairy Science, v.69, p.4570, 1991. 
HOOVER, C.W \& STOKES, S.R. Balancing carbohydrates and proteins for optimum rumen microbial yield. Journal of Dairy Science, v.74, p.3630-44, 1991.

HUBER, J.T.; HERRERA-SALDANHA, R. Synchrony of protein and energy supply to enhance fermentation. In: J.M. Asplund. Principles of Protein Nutrition of Ruminants., ed. C.R.C. Press, Boca Raton, Florida, 1994.

HUBER, J.T.; JACOBSON, N.L.; McGILLIARD, A.D.; ALLEN, R.S. Utilization of carbohydrates introduced directly into the omaso-abomasal area of the stomach of cattle of various age. Journal of Dairy Science, v.44, p.321-329, 1961.

HUNGATE, R. E. The Rumen and Its Microbes. Academic Press, New York, 1966.

HUNTINGTON, G. B.; PRIOR, R. L.; BRITTON, R. A. Glucose and lactate absorption and metabolic interrelationships in steers changed from low to high concentrate diets. Journal of Nutrition, v.111, p.1164, 1981.

HUNTINGTON, G.B.; REYNOLDS, P.J. Net absorption of glucose, L- lactate, volatile fatty acids, and nitrogenous compounds by bovine given abomasal infusions of starch or glucose. Journal of Dairy Science . v. 69, p.2428, 1986.

HUNTINGTON, G. B. Ruminant starch utilization progress has been extensive. Feedstuffs, June 6, p 35, 1994.

HUNTINGTON, G. B. Starch utilization bu ruminants: From basics to the bunk. Journal of Animal Science, v.75, p.852-867, 1997.

JOY, M. T; DePETERS, J.; FADEL, J. G.; Zinn, R. A. Effects of corn processing on the site and extent of digestion in lactating cows. Journal of Dairy Science, v.80, p.2087-2097, 1997. 
KNOWLTON, K. F.; ALLEN, M. S.; ERICKSON, P. S. Lasalocid and particle size of corn grain for dairy cows in early lactation. 1. Effect on performance, serum metabolites, and nutrient digestibility. . Journal of Dairy Science, v.79, p.559, 1996.

KOTARSKI, S. F.; WANISHA, R. D.; THURN, K. K.; Starch hidrolysis by the ruminal microflora. Journal of Nutrition, v.122, p.178-190, 1992.

KREIKEMEIER, K. K.; HARMON, D. L.; BRANDT, Jr. Et al. Small intestinal starch digestion in steers : effectc of various levels of abomasal glucose, corn starch and corn corn dextrin infusion on small intestinal disappearance and net glucose absorption. Journal of Animal Science, v. 69, p. 328, 1991.

KRONFELD, D.S.; RAGGI, F.; RAMBERG, C.F. Mammary blood flow and ketone metabolism in normal, fasted and ketotic cows. Journal of Animal Physiology, p. 215:218, 1968.

LOGGINS, P. E.; AMMERMAN, C. B.; ARRINGTON, L. R.; MOORE, J. E.; SIMPSON, C. F. Pelleted rations high in citrus by- products and corn for fattening lambs. Journal of Animal Science, v. 27, p.745, 1964.

LUCCI, C.S.; VELLOSO, L.; MASOTTI, N.; RENNÓ, F. P.; BECCKER, M. Polpa seca de laranja versus milho desintegrado, em misturas concentradas para vacas em lactação. Revista da Faculdade de Medicina Veterinária e Zootecnia da Universidade de Universidade São Paulo, v.12, p.163-168, 1975.

LYKOS, T.; VARGA, G. A.; CASPER. D. Varying degradation rates of total nonstrutural carbohydrates: Effects on ruminal fermentation, blood metabolites, and milk production and composition in high producing holstein cows. Journal of Dairy. Science, v. 80, p. 3341-3355, 1997. 
MEHREZ, A Z.; ORSKOV, E. R.; MC DONALD, I. Rates of rumen fermentation in relation to ammonia concentration. British Journal of Nutrition, v. 38, p. 433, 1977.

MITZNER, K. C.; OWEN, F. G.;GRANT. R. J. Comparison of sorghum and corn grains in early and midlactation diets for dairy cows. Journal of Dairy Science, v. 77, p. 1045- 1051, 1994.

MOORE, J. A.; POORE, M. H.; ECK, T. P.; SWINGLE, R. S. et. al. Sorghum grain processing and buffer adition for early lactation cows. Journal of Dairy Science, v.75, p. 3465, 1992.

MOE P. W. \& TYRRELL, H. F. Effects of feed intake and physical form on energy value of corn in timothy hay diets for lactating cows. Journal of Dairy Science, v.60, p. 753, 1976.

McAllister, T. A.; BAE, H. D.; JONES, G. A.; CHUNG, K. J. Microbial attachment and feed digestion in the rumen. Journal of Animal Science, v.72, p.3004, 1994.

McCARTHY, R. D.; JR., KLUSMEYER, J. L.; VICINI, J. L.; CLARK, J. H.; NELSON, D. R. Effects of source of protein and carbohydrate on ruminal fermentation and passage of nutrients to the small entestine of lactating cows. Journal of Dairy Science, v. 72, p. 2002-16, 1989.

McCUllOUGH, M. E. Some selections from recent meetings In: Macs Comments on Dairy Cattle Nutrition, v. 14, n.8, 1995. 
NOCEK, J. E. \& TAMMINGA, S. Site of digestion of starch in the gastrointestinal tract of dairy cows and its effect on milk and composition. Journal of Dairy Science, v.74, p.3598, 1991 .

NATIONAL RESEARCH COUNCIL. Ruminant Nitrogen Usage, Washington, D.C., 1985.138 p.

NATIONAL RESEARCH COUNCIL. Nutrient requeriments of dairy cattle., 6 ed, Washington , D.C., 1989. 157 p.

NUSSIO, L. G; HUBER, J. T; THEURER, C. B. et al. Effects of NDF and rumen degradable starch (RDS) ratio on performance of early pospartum dairy cows. Journal of Dairy Science, v.79 (Suppl.1), p.212, 1996 a.

NUSSIO, L. G; HUBER, J. T; THEURER, C. B. et al. Effects of NDF and rumen degradable starch (RDS) ratio on performance of mid lactation dairy cows. Journal of Dairy Science, v.79 (Suppl.1), p.212, 1996 b.

NUSSIO, L. G. Effects of NDF levels and ruminally degradable starch on performance, ruminal parameters and in situ degradation of nutrients in lactating dairy cows fed sorghum diets. Ph.D. Dissertation. University of Arizona, Tucson, 1997.

ODLE, J.; SCHAEFER; D. M. Influence of rumen ammonia concentration on the rumen degradation rates of barley and maize. British Journal of Nutrition, v.57, p.127, 1987.

OLIVEIRA, J. S.; HUBER, J. T.; BEN-GHEDALIA D.; SWINGLE R. S.; THEURER C. B.; PESSARAKLI, M. Influence of sorghum grain processing on performance of lactating dairy cows. Journal of Dairy Science, v.76, p.575, 1993. 
OLIVEIRA, J. S.; HUBER J. T.; SIMAS, J. M.; THEURER, C. B.; SWINGLE, R.S. Effect of sorghum grain processing on site and extent of digestion of starch in lactating dairy cows. Journal. Dairy Science, v.78, p.1318, 1995.

ORSKOV, E.R The feeding of ruminants - principles and practice. Rowett Research Institute, Chalcombe Publications, 1987.

ORSKOV, E.R Starch digestion and utilization in ruminant. Journal of Animal Science, v. 63, p. 1624, 1986.

OWENS, F.; ZINN, R. A.; KIM, Y. K. Limits to starch digestion in the ruminant small intestine. Journal of Dairy Science, v.63, p.1634, 1986.

OWENS, F. N.; GOETSCH, A. L. Digesta passage and microbial protein synthesis. In: L.P. Milligan. Control of Digestation and Metabolism in Ruminants . New Jersey :W.L.Grovum, and A. Dobson, p. 196-223, 1986.

OWENS, F. N. Protein Metabolism of Ruminant Animals. In: D. C. Church. The Ruminant Animal Digestive Physiology and Nutrition. New Jersey :Prentice Hall, Englewoog Cliffs, p. 227- 249, 1988.

PALMQUIST, D. AND H. CONRAD. Origin of plasma fatty acids in lactating cows fed high grain or high fat diets. Journal of Dairy Science, v.54, p.1025, 1971.

PINZON, F. J.; WING, J. M. Effects of citrus pulp in high urea rations for steers. Journal of Dairy Science, v.59, p.1100, 1976.

PLASCENCIA, A.; ZINN, R. A.;. Influence of flake density on the feeding value of steam-processed corn in diets for lactating cows. Journal of Animal Science, v.74, p.:310-316, 1996. 
POORE, M. H.; ECK, T. P.; SWINGLE, R. S.; THEURER, C. B. Total starch and relative starch availability of feed grains. ABSTR. 35, 20th Biennial Conference on Rumen Function, Chicago, 1989.

POORE, M. H.; MOORE, J. A.; SWINGLE, R. S.; ECK, T. P.; BROW, W. H. Wheat straw or alfafa hay in diets with $30 \%$ neutral detergent fiber for lactating Holstein cows. Journal of Dairy Science, v. 74, p.3152, 1991.

POORE, M. H.; MOORE, J. A.; ECK, T. P.; SWINGLE, R. S.; THERER, C. B. Effect of fiber source and ruminal starch degradability on site and extent of digestion in dairy cows. Journal of Dairy Science, v. 76, p. 2244-53, 1993.

REYNOLDS, C. K.; HARMON, D. L.; CECAVA, M. J. Absorption and delivery of nutrientes for milk protein synthesis by portal-drained viscera. Journal of Dairy Science, v. 77, p.2787, 1994.

REYNOLDS, C. K.; HUNTINGTON, G. B.; TYRREL, H. F.; REYNOLDS, P. L. Net portal-drained visceral and hepatic metabolism of glucose, lactate, and nitrogenous compounds in lactating dairy holstein cows . Journal of Dairy. Science, v.71, n.7, p.1803-1812, 1988a.

REYNOLDS, C. K.; HUNTINGTON, G. B.; TYRREL, H. F.; REYNOLDS, P. L. Net metabolism of volatile fatty acids, D- $\beta$-hydroxibutyrate, nonesterified fatty acids, and blood gases by portal-drained viscera and liver of lactating holstein cows. Journal of Dairy Science, v.71, n.9, p. 2395:2405, 1988b.

REYNOLDS, C. K. \& HUNTINGTON, G. H. Net portal absorption of volatile fatty acids and L (+) lactate by lactating holstein cows. Journal of Dairy Science, v.71, n.1, p.124-136, $1988 \mathrm{c}$. 
ROBERTSON, J. B.; VAN SOEST, P. J. The detergent system of analysis and its application to human foods. In: James, W.P.T. e Theander, O. Analysis of Dietary Fiber in Food. New York: Marcel Dekker, 1981. v. 3, p. 123.

ROCHA FILHO, R. R. Efeitos da polpa de citrus e do milho sobre parâmetros ruminais. Piracicaba, 1998. 71p. Dissertação (M.S.) Escola Superior de Agricultura Luiz de Queiroz, Universidade de São Paulo.

RODE, L. M.; WEAKLEY, D. C.; SATTER, L. D. Effect of forage amount and particle size in diets of lactating dairy cows on site of digestion and microbial protein synthesis. Canadian Journal of Anima I Science, v.65, p.101, 1985.

ROONEY, L. W. \& PFLUGFELDER, R. L. Factors affecting starch digestibility with special emphasis on sorghum and corn. Journal of Animal Science, v.63, p.1607, 1986.

ROONEY, L. W \& MILLER, F. R. Variation in the structure and kernel characteristics of sorghum. Procedings Sorghum Grain Quality Symp. p. 143-161..India, 1982.

RUSSELL, J. B.; O CONNOR, J.D.; FOX, D. G.; VAN SOEST, P. J.; SNIFFEN, C. J. A net carbohydrate and protein system for evaluating cattle diets. I. Ruminal fermentation. Journal of Animal Science, v.70, p. 3551-61, 1992.

RULQUIN, H. \& VERITÉ, R. Amino acid nutrition of dairy cows: Produtive effects and animal requeriments. In : Recent Advances in Animal Nutrition. Nottingham: Univ. Press, P.C. Garnsworthy and D.J.A. Cole (Editors), p. 55, 1993.

SANTOS, F. A. P. \& HUBER, J. T. Effects of rumen undegradable protein(RUP) on dairy cow performance: A 10 year literature review. Journal of Dairy Science, v.78, n.1, p.293, 1995. 
SANTOS, F. A. P. Effect of sorghum grain processing and protein source on performance and nutrient utilization by lactating dairy cows 1996 . PhD Dissertation. University of Arizona. 1996.

SANTOS, F. A . P.; HUBER, J. T.; THEURER, C. B. et al. Response of lactating dairy cows to various densities of sorghum grain. Journal of Dairy Science, v.75, p.1681$1685,1997$.

SANTOS, F. A. P. Efeito de fontes protéicas e processamento de grão no desempenho de vacas de leite e digestibilidade dos nutrientes. Tese de Livre Docência, ESALQ/USP, 1998.

SAS Users Guide: Statistics, Version 5 Edition. 1991. SAS Inst., Inc., Cary, NC.

SATTER, L. D.; SLYTER, L. L. Effect of ammonia concentration on rumen microbial protein production in vitro. British Journal of Nutrition, v.32, p.199, 1974

SCHAILBLY, G. E.; WING, J. M. Effects of roughage concentrate ration on digestibility and rumen fermentation of corn silage citrus pulp rations. Journal of Animal Science, v. 38, p. 697, 1974.

SCHWAB, C. G. Optimizing amino acid nutrition for optimun yields of milk and milk protein. Proc. Southwest Nutr. Manage. Conf. Univ. Arizona, Tucson, p. 114, 1994.

SHULTZ, T. A.; COLLAR, C. A ; BATH, D. L.; AHMADI, A. Rumen digestion of various dairy feedstuffs compared in tests. California Agriculture, may-jun. 3, 1993. 
SIMAS, J. M. Processamento de grãos para rações de vacas leiteiras . In: $9^{\circ}$ SIMPÓSIO SOBRE PRODUÇÃO ANIMAL,. Piracicaba, 1997. Anais. p.732.Piracicaba:FEALQ, 1997.

SLYTER, L. L.; SATTER, L. D.; DINIUS, D. A. Effect of ruminal ammonia concentracion on nitrogen utilization by steers. Journal of Animal Science, v. 48, p.906-12, 1979.

SNIFFEN, C. J. The use of by-pass protein in ration formulation. In: Proc. 40th American Feed Manu fact. Assoc. Nut. Council, 1980, p. 40.

SNIFFEN, C. J. Balancing rations for carbohydrates for dairy cattle. In: Proceedings of the 1988 Feed Dealer Seminars, Cornell Cooperative Extension, n.112, p.9-19, 1988.

SNIFFEN, C. J; O CONNOR, J. D.; VAN SOEST, P. J.; FOX, D.G.; RUSSEL, J. B. A net carbohydrate and protein system for evaluating cattle diets. II Carbohydrate and protein availability. Journal of Animal Science, v. 70, p.3562-77, 1992.

SPICER, L. A.; THEURER, C. B.; SOWE, J.; NOON, T. H. Ruminal and post-ruminal utilization of nitrogen and starch from sorghum grain, corn, and barley based diets by beef steers. Journal of Animal Science, v.62, p.521, 1986.

STEINHOUR, W.D.; BAUMAN, D. E. Propionate metabolism: A new interpretation . In: Aspects of Digestive Physiology in Ruminantes. Comstock, Ithaca, NY. Dobson, A. Dobson, M.J. eds, 1988, p. 238-256.

STERN, M. D. \& ZIEMER C. J. Consider value, cost when selecting nonforage fiber. Feedstuffs, january 11, 1993, p.14. 
STOKES, S. R.; HOOVER, W. R.; MILLER, T. K.; MANSKI, R. P. Ruminal digestion and microbial utilization of diets varying in type of carbohydrate and protein. Journal of Dairy Science, v.74, p. 871, 1991(b).

STROBEL, H. J.; RUSSEL, J. B. Effect on $\mathrm{pH}$ and energy spilling on bacterial protein syntesis by carbohydrate-limited cultures of mixed rumen bacteria. Journal of Dairy Science, v.69, p. 2941- 2947, 1986.

SUTTON, J. D.; BINES, J. A.; MORATI, S. V. ; NAPPER, D. J. A comparison of starch and fibrous concentrates for milk production, energy utilization and hay intake by Friesian cows. Journal of Agricultu ral Science, v.109, p. 375-386, 1987.

TEIXEIRA, J. C.; CAlESTINE, G. A.; BELlATO, M. S. e PEREZ, J. R. O. Degradabilidade ruminal da matéria seca, energia bruta do amido de diferentes alimentos energéticos, em vacas das raças holandesa e jersey. Anais da XXXIV Reunião da Sociedade Brasileira de Zootecnia. Juiz de Fora-MG, 1997.

THEURER, C. B. Grain processing effects on starch utilization by ruminants. Journal of Animal Science, v. 63, p.1649, 1986.

THEURER, C. B.; OLIVEIRA, J. S.; WU, Z.; HUBER, J. T.; SWINGLE, R. S. et al. Steam-flaking with two dietary grain levels improves digestible starch intake and performance by lactating cows. Journal of Dairy Science, v.74 (suppl.1), p.246, 1991.

THEURER, C. B. Steam-flaked grain for high producing dairy cows. Page 64 in Proc. Southwest Nutr. Manage Conf., Dep. Animal Science, Univ. Arizona, Tucson, 1992. 
THEURER, C. B.; Huber , J. T.; Santos, F. A. P. Feeding and managing for maximal milk protein. $\mathrm{Pg} 59$ in Proc. Southwest Nutr. Manage. Conf. Univ. Arizona,Tucson, 1995.

TIETZ, N. W. Fundamental of Clinical Chemistry, 2 ed., Philadelphia, Saunders, 1982. $240 \mathrm{p}$.

VAN HORN, H. S.; MARSHALL, S.P.; WILCOX, J.C.; RANDEL, P. F.; WING, J. M. Complete rations for dairy cattle. III. Evaluation of protein percent and quality and citrus pulp-corn substitutions. Journal of Dairy Science, v.58, p.1101-1108, 1975.

VAN SOEST, P. J. Nutrition ecology of the ruminants. Corvallis, Oregon: O \& Books, 1982. $373 \mathrm{p}$.

VAN SOEST, P. J. Nutrition ecology of the ruminants. Ithaca,New York: Cornell UniversityPress, $1994.476 \mathrm{p}$.

VAN SOEST, P. J . Soluble carbohydrates and the non-fiber componentes of feeds . Large Anim. Vet, V.42, P. 44, 1987.

VAN SOEST, P. J.; ROBERTSON J. B.; LEWIS B. A. Methods for dietary fiber, neutral detergent fiber, and nonstarch polysaccharides in relation to animal nutrition. Journal of Dairy Science, v.74, p. 3583-3596, 1991.

VALK, H.W.; KLEIN POELHUIS.; WENTINK, H J . Effects of fibrous and starchy carbohydrates in concentrates as supplements in a herbage-based diet for high yielding dairy cows. Netherlands Journal of Agricultural Science, v.38, p. 475486, 1990. 
VEENHUIZEN, J. J.; RUSSELL, R. W.; YOUNG, J .W. Knetics of metabolism of glucose, propionate and $\mathrm{CO}_{2}$ in steers as affected by injecting phlorizin and feeding propionate. Journal of Nutrition, v.118, p.1366, 1988.

WAINMAN, F. W. \& DEWEY, J. S. Feedingstuffs evaluation unit-fifth report. Rowett Research Institute, 1988. 123p.

WICKES, R. B. \& BARTSCH, B. D. Dried citrus pulp or barley as energy concentrates for dairy cows. Proceedings of the Australian Society of Animal Production, v.12, p.180, 1978. /Resumo em CAB Abstracts on CD-ROM, 1978.

WILKERSON, V. A ; GLEIN, B. P.; McLEOD. K. R. Energy and nitrogen balance in lactating cows fed diets containing dry or high moisture corn in either rolled or ground form. Journal of Dairy Science, v.80, p. 2487-2496, 1997.

WING, J. M. Effects of physical form and amount of citrus pulp on utilization of complete feeds for dairy cattle. Journal of Dairy Science, v.58, p. 63, 1975.

WING, J. M. Citrus Feedstuffs for Dairy Cattle. Gainsville: University of Flórida (Bulletin 829). Agricultural Experiment. Station, 1982, 25p.

YOKOYAMA M. T.; JOHNSON, K. A. Microbiology of the rumen and intestine. In: The Ruminant Animal Digestive Physiology and Nutrition. D.C. Church, ed. Prentice Hall, Englewood Cliffs, New Jersey, 1988, p. 125.

YU, P.; HUBER, J. T.; THEURER, C. B. et al. Effects of steam- flaked or steam-rolled corn with or without Aspergillus oryzae in the diet on performance of dairy cows fed during hot weather. Journal of Dairy Science, v.80, p. 3293-3297, 1997. 
YU, P.; HUBER, J. T.; SANTOS, F. A P. et al. Effects of ground, steam- flaked, and steam-rolled corn grains on performance of lactating cows. Journal of Dairy Science, v.81, p. 777-783, 1998. 